\title{
CHARACTERIZATION OF STORMWATER RUNOFF IN SIOUX FALLS, SOUTH DAKOTA, 1995-96
}

U.S. GEOLOGICAL SURVEY

Water-Resources Investigations Report 97-4070

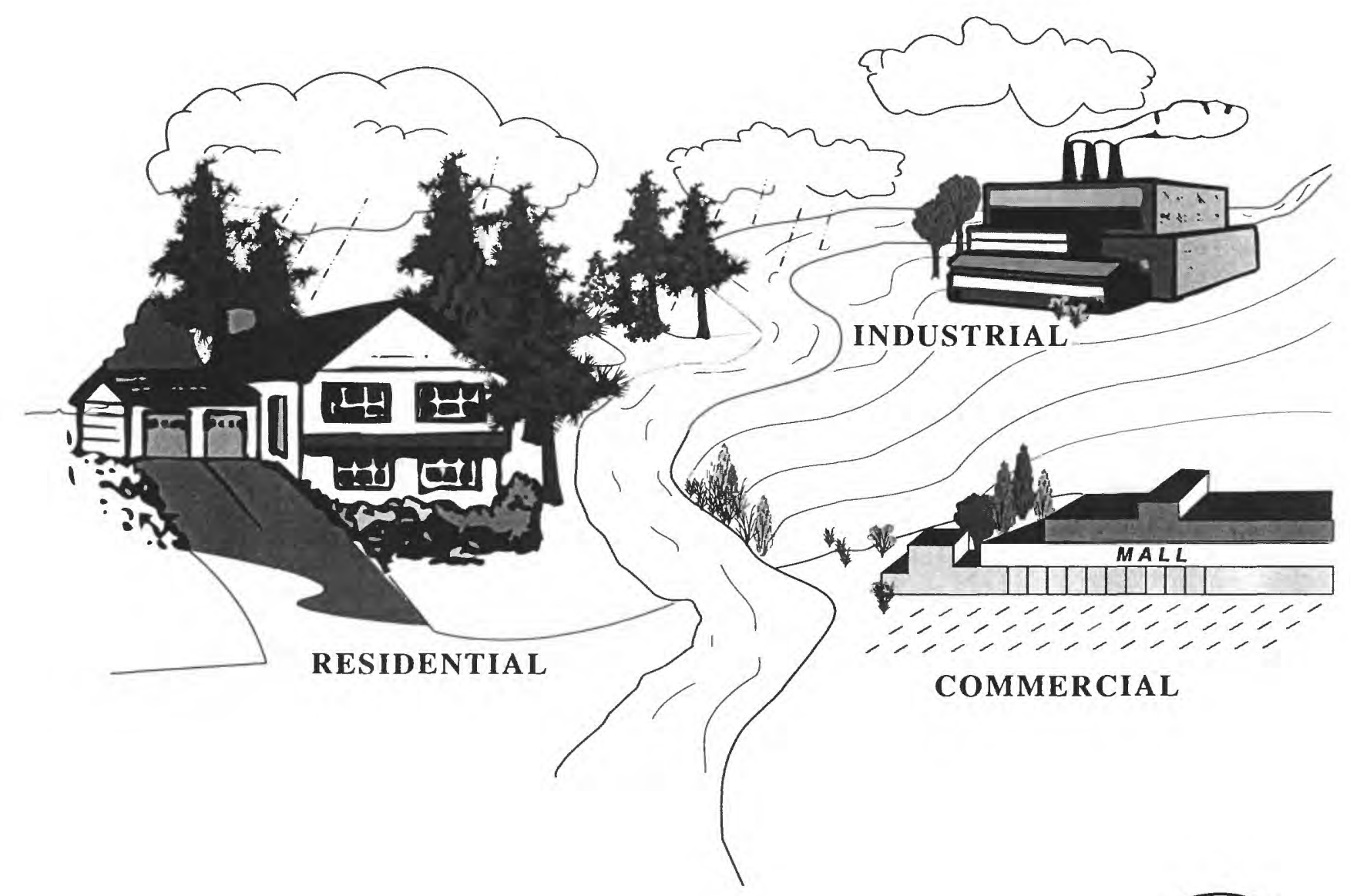

Prepared in cooperation with the CITY OF SIOUX FALLS, SOUTH DAKOTA

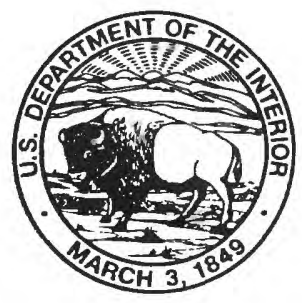




\section{CHARACTERIZATION OF STORMWATER RUNOFF IN SIOUX FALLS, SOUTH DAKOTA, 1995-96}

By COLIN A. NIEHUS

\section{U.S. GEOLOGICAL SURVEY}

Water-Resources Investigations Report 97-4070

Prepared in cooperation with the

CITY OF SIOUX FALLS, SOUTH DAKOTA 


\section{U.S. DEPARTMENT OF THE INTERIOR \\ BRUCE BABBITT, Secretary}

\section{U.S. GEOLOGICAL SURVEY}

Gordon P. Eaton, Director

The use of trade, product, or firm names in this report is for identification purposes only and does not constitute endorsement by the U.S. Geological Survey.

For addtional information write to:

\section{District Chief}

U.S. Geological Survey 1608 Mt. View Rd.

Rapid City, SD 57702
Copies of this report can be purchased from:

U.S. Geological Survey

Branch of Information Services

Box 25286

Denver, CO 80225-0046 


\section{CONTENTS}

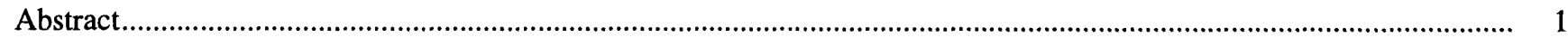

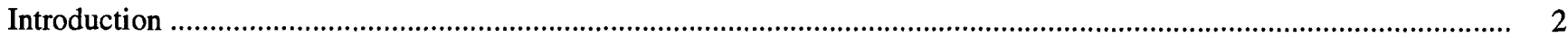

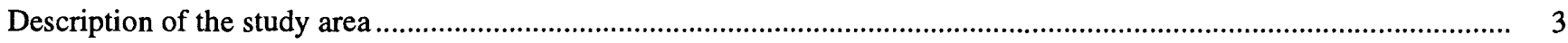

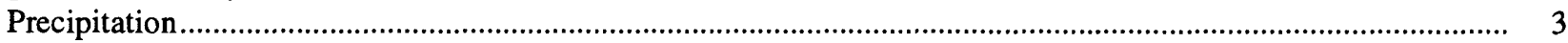

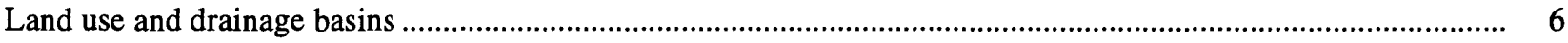

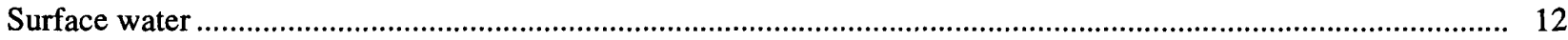

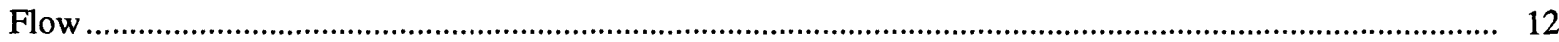

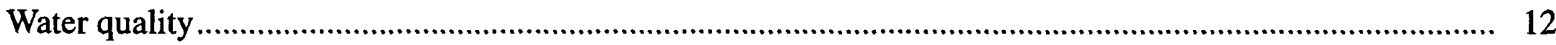

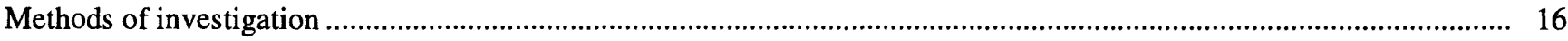

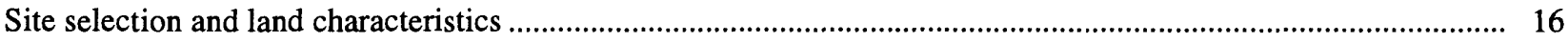

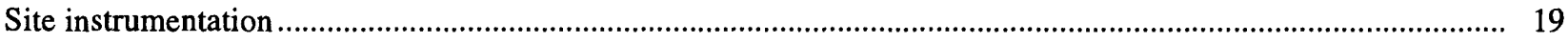

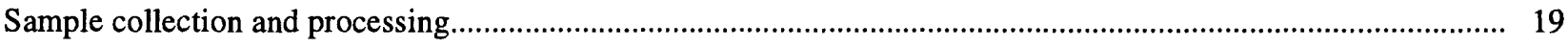

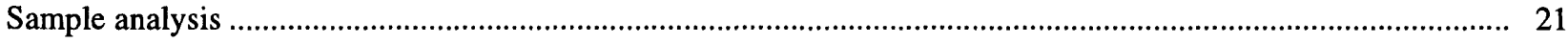

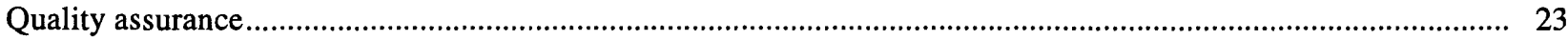

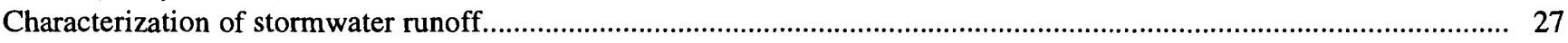

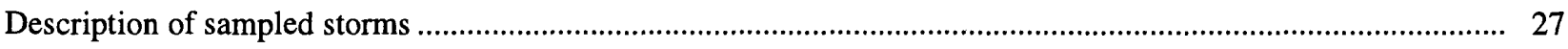

Concentrations of selected constituents or properties in stormwater runoff ................................................. 41

Estimated annual loads of selected constituents or properties in stormwater runoff ........................................ 51

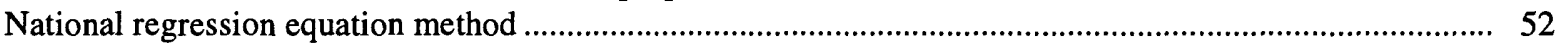

U.S. Environmental Protection Agency simple method ................................................................... 53

Estimated event-mean concentrations of selected constituents or properties in stormwater runoff......................... 55

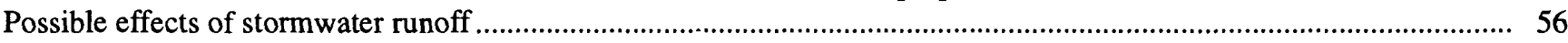

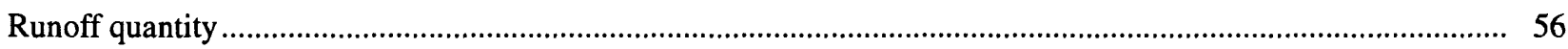

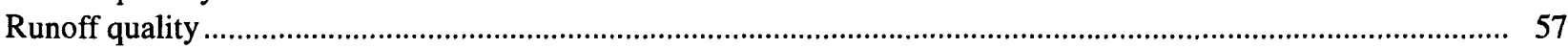

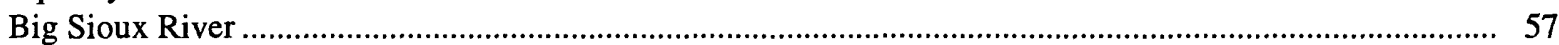

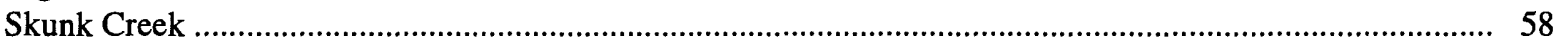

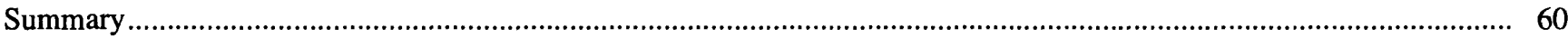

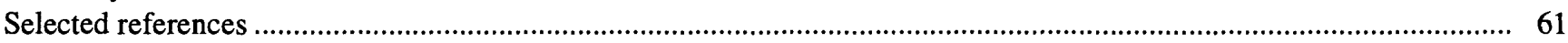

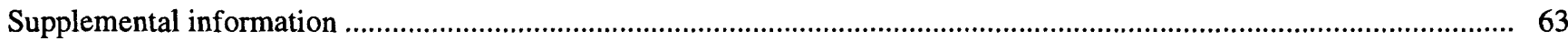

\section{ILLUSTRATIONS}

1. Map showing locations of streamflow and water-quality sites within and near Sioux Falls ...................................

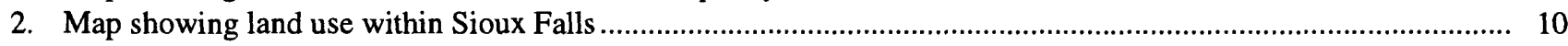

3. Map showing drainage basins within and near Sioux Falls .......................................................................

4. Boxplots showing distribution of selected chemical analyses of water from selected U.S. Geological Survey streamflow-gaging stations within and near Sioux Falls ............................................ 14

5. Map showing stormwater-runoff sampling sites and corresponding drainage basins and land use within and near Sioux Falls

6. Graphs showing gage height, discharge, and cumulative rainfall for the storm events sampled at the commercial site.

7. Graphs showing gage height, discharge, and cumulative rainfall for the storm events sampled at the industrial site

8. Graphs showing gage height, discharge, and cumulative rainfall for the storm events sampled at the residential site.

9. Graph showing measured specific conductances from 1973 to 1995 at USGS streamflow-gaging station 06482020, Big Sioux River at North Cliff Avenue, at Sioux Falls. 


\section{ILLUSTRATIONS-Continued}

10. Graph showing measured specific conductances from 1973 to 1995 at USGS streamflow-gaging station 06481500, Skunk Creek at Sioux Falls

\section{TABLES}

1. Annual and monthly storm and precipitation characteristics for $1949-88$ for Sioux Falls................................ 5

2. Land-use classification within and near Sioux Falls......................................................................................

3. Drainage basins within and near Sioux Falls........................................................................................ 7

4. Characteristics of the Big Sioux River, Skunk Creek, and Covell Lake within and near Sioux Falls .................. 13

5. Characteristics of land uses and drainage basins of urban stormwater-runoff sampling sites within Sioux Falls

6. Collection, processing, and analysis information associated with the sampling of stormwater runoff in Sioux Falls

7. Laboratory methods of analysis for selected constituents or properties for stormwater runoff in Sioux Falls...

8. Quality-assurance results of field-equipment blanks for flow-weighted constituents or properties collected at the industrial site

9. Quality-assurance results of field replicates for grab constituents or properties collected at the commercial site

10. Characteristics of stormwater runoff sampled during 1995-96 in Sioux Falls...

11. Concentrations of selected constituents or properties in grab-collected stormwater runoff at sampling sites within Sioux Falls

12. Concentrations of selected constituents or properties in flow-weighted stormwater runoff at sampling sites within Sioux Falls

13. Concentrations of constituents or properties detected in stormwater runoff at sampling sites within Sioux Falls

14. Concentrations of constituents or properties in stormwater runoff for which annual loads were calculated in Sioux Falls

15. Percent imperviousness and runoff coefficients of major land uses in Sioux Falls.

16. U.S. Geological Survey national regression equations for determining annual loads of selected constituents or properties

17. Estimated annual loads of selected constituents or properties in stormwater runoff in Sioux Falls, using U.S. Geological Survey national regression equations and U.S. Environmental Protection Agency methods

18. Estimated event-mean concentrations of selected constituents or properties in stormwater runoff in Sioux Falls

19. Summary of trend tests on specific conductance for water from the U.S. Geological Survey streamflow-gaging stations in Sioux Falls on the Big Sioux River (North Cliff Avenue, at Sioux Falls) and Skunk Creek (Skunk Creek at Sioux Falls). 


\begin{tabular}{|c|c|c|}
\hline Multiply & By & To obtain \\
\hline \multicolumn{3}{|c|}{ Length } \\
\hline inch & 2.54 & centimeter \\
\hline inch & 25.4 & millimeter \\
\hline foot & 0.3048 & meter \\
\hline mile & 1.609 & kilometer \\
\hline \multicolumn{3}{|c|}{ Area } \\
\hline acre & 4,047 & square meter \\
\hline acre & 0.4047 & hectare \\
\hline square mile & 259.0 & hectare \\
\hline square mile & 2.590 & square kilometer \\
\hline \multicolumn{3}{|c|}{ Volume } \\
\hline ounce & 0.02957 & liter \\
\hline gallon & 3.785 & liter \\
\hline gallon & 0.003785 & cubic meter \\
\hline cubic foot & 28.32 & cubic decimeter \\
\hline cubic foot & 0.02832 & cubic meter \\
\hline \multicolumn{3}{|c|}{ Flow rate } \\
\hline cubic foot per second & 0.02832 & cubic meter per second \\
\hline \multicolumn{3}{|c|}{ Mass } \\
\hline pound & 0.4536 & kilogram \\
\hline pound per gallon & 0.1198 & kilograms per liter \\
\hline \multicolumn{3}{|c|}{ Pressure } \\
\hline pound per square inch & 6.895 & kilopascal \\
\hline
\end{tabular}

Temperature in degrees Celsius $\left({ }^{\circ} \mathrm{C}\right)$ may be converted to degrees Fahrenheit $\left({ }^{\circ} \mathrm{F}\right)$ as follows:

$$
{ }^{\circ} \mathrm{F}=\left(1.8 \times{ }^{\circ} \mathrm{C}\right)+32
$$

Temperature in degrees Fahrenheit $\left({ }^{\circ} \mathrm{F}\right)$ may be converted to degrees Celsius $\left({ }^{\circ} \mathrm{C}\right)$ as follows:

$$
{ }^{\circ} \mathrm{C}=\left({ }^{\circ} \mathrm{F}-32\right) / 1.8
$$

Abbreviated water-quality units used in this report: Chemical concentrations given in milligrams per liter $(\mathrm{mg} / \mathrm{L})$ or micrograms per liter $(\mu \mathrm{g} / \mathrm{L})$ express the concentrations of constituents in solution as weight (milligrams or micrograms) of solute per unit volume (liter) of water.

Sea level: In this report, "sea level" refers to the National Geodetic Vertical Datum of 1929 (NGVD of 1929) - a geodetic datum derived from a general adjustment of the first-order level nets of both the United States and Canada, formerly called Sea Level Datum of 1929.

Symbols: $>$, greater than

$<$, less than 


\title{
Characterization of Stormwater Runoff in Sioux Falls, South Dakota, 1995-96
}

\author{
By Colin A. Niehus
}

\begin{abstract}
Urban stormwater runoff was characterized and effects of the stormwater runoff on receiving waters were determined in Sioux Falls, South Dakota. The study included collecting stormwater runoff at three sites considered representative of commercial, industrial, and residential land uses and analyzing for selected constituents or properties; estimating annual loads and event-mean concentrations of selected constituents or properties in stormwater runoff; evaluating the effects of the quantity of stormwater runoff on receiving waters; and analyzing trends in specific conductance of receiving waters.
\end{abstract}

Stormwater-runoff samples were collected during 1995 and 1996 at three sites in Sioux Falls that were considered representative of commercial, industrial, and residential land uses. The first sampling site was considered representative of commercial land use and was located at the southwest edge of Sioux Falls in an open channel upstream of two 72-inch culverts that drain into the Big Sioux River. The second sampling site was considered representative of industrial land use and was located at the north-central edge of Sioux Falls in an open channel upstream of two 48-inch culverts that drain into the Big Sioux River Diversion Channel. The third sampling site was considered representative of residential land use and was located at the southwest edge of Sioux Falls in a concrete-lined open channel upstream of three 54-inch culverts that drain into Skunk Creek.

Stormwater runoff was sampled at the three sites from storms that had total rainfall that ranged from 0.16 to 0.75 inch. The collected samples were analyzed for nearly 150 constituents or properties including chemical and biochemical oxygen demands, bacteria, major ions, dissolved and suspended solids, nutrients, metals and trace elements, cyanide, and organics (volatile, base/ neutral, acid, and pesticide compounds). Stage, discharge, and rainfall were measured at each site during representative storms. Four sets of stormwater samples were collected at each sampling site during six representative storm events.

Annual loads and event-mean concentrations in stormwater runoff were estimated for chemical oxygen demand, biochemical oxygen demand, dissolved solids, suspended solids, total Kjeldahl nitrogen, total nitrogen, total phosphorus, dissolved phosphorus, total cadmium, total copper, total lead, and total zinc. Annual loads were estimated using the national regression equations developed by the U.S. Geological Survey and using the "simple method" recommended by the U.S. Environmental Protection Agency. Load calculations by the "simple method" generally were larger than those determined using national regression equations. Event-mean concentrations were calculated using estimated annual loads, annual rainfall, drainage areas, weighted-average runoff coefficients, and correction factors.

Possible effects of the quantity of Sioux Falls stormwater runoff on receiving water bodies were investigated. The volume and discharge of stormwater runoff to receiving waters were estimated to show how it compares to the discharge in the Big Sioux River and Skunk Creek. During low flows in the Big Sioux River and Skunk Creek, the 
runoff from an average storm event could represent a significant portion of the stream discharges, thereby affecting the water quality of Skunk Creek and the Big Sioux River within and downstream of Sioux Falls.

Trends in specific conductance (an approximate indicator of the dissolved solids in water) from receiving waters (Big Sioux River and Skunk Creek) were analyzed to study any changes in water quality of the receiving waters in Sioux Falls. Examination of a plot of specific conductance versus time (1973-95) for water from the Big Sioux River indicates a possible negative trend in conductance. Regression of conductance versus time supports this observation. Statistical-trend tests that take into account the flow and seasonal effects did not indicate that a significant trend was present in specific conductance in the Big Sioux River.

The effects of urbanization on specific conductance of water from Skunk Creek also were investigated using similar methods that were used on the Big Sioux River. Examination of a plot of specific conductance versus time (1973-95) for water from Skunk Creek and regression of conductance versus time did not indicate that a significant trend was present. Statistical-trend tests that take into account flow and seasonal effects indicated a significant positive trend.

\section{INTRODUCTION}

Prior to the 1980's, urban stormwater runoff was considered to be an insignificant source of contamination of receiving waters. However, the National Urban Runoff Program (NURP) studies conducted by the U.S. Environmental Protection Agency (USEPA) from 1978-83 found that urban stormwater runoff could have detrimental effects on receiving waters (U.S. Environmental Protection Agency, 1983). Under Section 402(p) of the Water Quality Act of 1987, the USEPA is required to regulate stormwater discharge from municipalities with a population of 100,000 or more under the National Pollutant Discharge Elimination System (NPDES) program. In November 1990 , the USEPA published final rules for obtaining the NPDES permits required under these regulations.
Under these rules, the City of Sioux Falls, South Dakota, submitted a permit application consisting of two parts. Part I of the application provided an adequate basis for identifying and characterizing sources of pollutants to receiving waters. Part II of the application provided information for the preparation of management plans that stress source controls of pollutants in urban stormwater runoff.

The U.S. Geological Survey (USGS) provided technical assistance to the City of Sioux Falls for the NPDES work. The USGS cooperated with the City of Sioux Falls during 1993-97 to characterize urban stormwater runoff and to determine the effects of the stormwater runoff on receiving waters in Sioux Falls. The study included collecting stormwater runoff at three sites considered representative of commercial, industrial, and residential land uses and analyzing for selected constituents or properties; estimating annual loads and event-mean concentrations of selected constituents or properties in stormwater runoff; evaluating the effects of the quantity of stormwater runoff on receiving waters; and analyzing trends in specific conductance of receiving waters.

Stormwater runoff collected from the three predominant land uses was used to represent runoff from all the land uses in Sioux Falls. The samples that were collected were analyzed for chemical and biochemical oxygen demands, bacteria, major ions, dissolved and suspended solids, nutrients, metals and trace elements, cyanide, and organics (volatile, base/neutral, acid, and pesticide compounds).

This report describes results of the study. Results from this study will aid other cities with similar environmental settings in evaluating and managing their water resources. Results of the study also will assist policy makers in determining the effectiveness of stormwater-management practices and in developing future stormwater-management programs.

The author acknowledges the cooperation of Sioux Falls municipal officials in providing information on the City's stormwater system, providing geographic information system (GIS) coverages of land use, and providing space in the Water Purification Plant for preparation of water samples for shipment to the laboratory. The assistance of the National Weather Service in Sioux Falls in providing detailed precipitation forecasts also was appreciated. Finally, the author thanks the residents and businesses near the samplecollection sites for allowing the installation of the equipment shelters and associated equipment. 


\section{DESCRIPTION OF THE STUDY AREA}

Sioux Falls is located in Minnehaha County in southeastern South Dakota (fig. 1). Sioux Falls is the largest city in South Dakota with a 1990 population of 100,814 (Sioux Falls Planning and Building Services Department, 1992). During the 10-year period from 1991 through 2000, the population of Sioux Falls is projected to increase from 100,836 to 121,255 , or an increase of over 20 percent (Sioux Falls Planning and Building Services Department, 1993). The population density is projected to increase from 3.2 persons per acre in 1990 to 3.7 persons per acre in 2015. This projection includes an increase of over 15 square miles in the size of the City by the year 2015. Population growth is expected to occur within and around the City in every direction, but especially to the east and south.

The study area (Sioux Falls) is located primarily in the Coteau des Prairies (Lindgren and Niehus, 1992). Pleistocene glacial deposits or nonglacial loess (windblown sand and silt) and stream deposits overlay the area. The glacial deposits are either till or outwash. The Big Sioux and Skunk Creek aquifers underlie the flood plains of the corresponding streams within and near Sioux Falls (Lindgren and Niehus, 1992). The bedrock unit underlying these deposits is the Sioux Quartzite, which locally is a well-fractured and jointed crystalline rock that will yield water to wells in amounts sufficient for domestic and municipal supplies.

The land surface ranges in altitude from less than 1,300 feet above sea level in the Big Sioux River bed in northeastern Sioux Falls to greater than 1,550 feet above sea level in east-central Sioux Falls. Much of Sioux Falls is between 1,450 and 1,500 feet above sea level.

The City is drained predominantly by the Big Sioux River, which flows through much of Sioux Falls. The Big Sioux River enters the City at the north edge, flows to near the south edge, and then loops back northward, exiting at the northeast edge. The City also is drained by Skunk Creek, a tributary of the Big Sioux River, located in the southwest part of Sioux Falls, and to a small extent by Covell Lake located in the northern part.

\section{Precipitation}

Precipitation data collected by the National Weather Service at the Sioux Falls airport (National
Oceanic and Atmospheric Administration, 1949-88) were used to characterize precipitation and storms for Sioux Falls. The annual and monthly representativestorm and precipitation characteristics for $1949-88$ for Sioux Falls are listed in table 1. The mean annual precipitation at Sioux Falls is 24.2 inches, with about 75 percent of this total occurring during the months of April through September $(2.4,3.1,3.6,2.7,3.0$, and 2.9 inches, respectively). Over 80 percent of the annual snowfall occurs during December through March (7.8, 6.7, 8.1, and 10.1 inches, respectively).

The Synoptic Rainfall Data Analysis Program (SYNOP), which was developed by the USEPA and the Federal Highway Administration, was used to determine storm characteristics for the $1949-88$ period and to estimate characteristics of representative storms. The program uses hourly precipitation records to estimate storm characteristics. Only storm events of at least 0.1 inch total precipitation that were preceded by at least 6 hours of dry weather were used to calculate characteristics of representative storms. The mean monthly and annual number of storm events, mean monthly storm volume in inches, mean monthly storm duration in hours, and mean monthly storm intensity in inches per hour are listed in table 1. A range for representative storms of \pm 50 percent of the mean storm volume, duration, and intensity also are included.

The SYNOP model indicated that the mean annual storm for Sioux Falls had a volume of 0.49 inch and a duration of 11.1 hours. Representative storms had a volume between 0.25 and 0.74 inch and a duration between 5.5 and 16.6 hours. An average of 43.4 storm events occurred each year; over 60 percent of these events occurred in months that historically do not have snowfall (May through September).

The mean monthly storms were similar in volume, but had a large variation in duration. The mean monthly storm volumes ranged from 0.29 inch in January to 0.64 inch in September. Nine of the months had mean storm volumes between 0.4 and 0.6 inch. The mean monthly storm durations varied between 4.5 hours in July and 16.0 hours in February. The months of November through March had an average mean monthly storm duration of 15.3 hours in contrast to the remaining seven months which had an average mean monthly storm duration of 8.1 hours. 


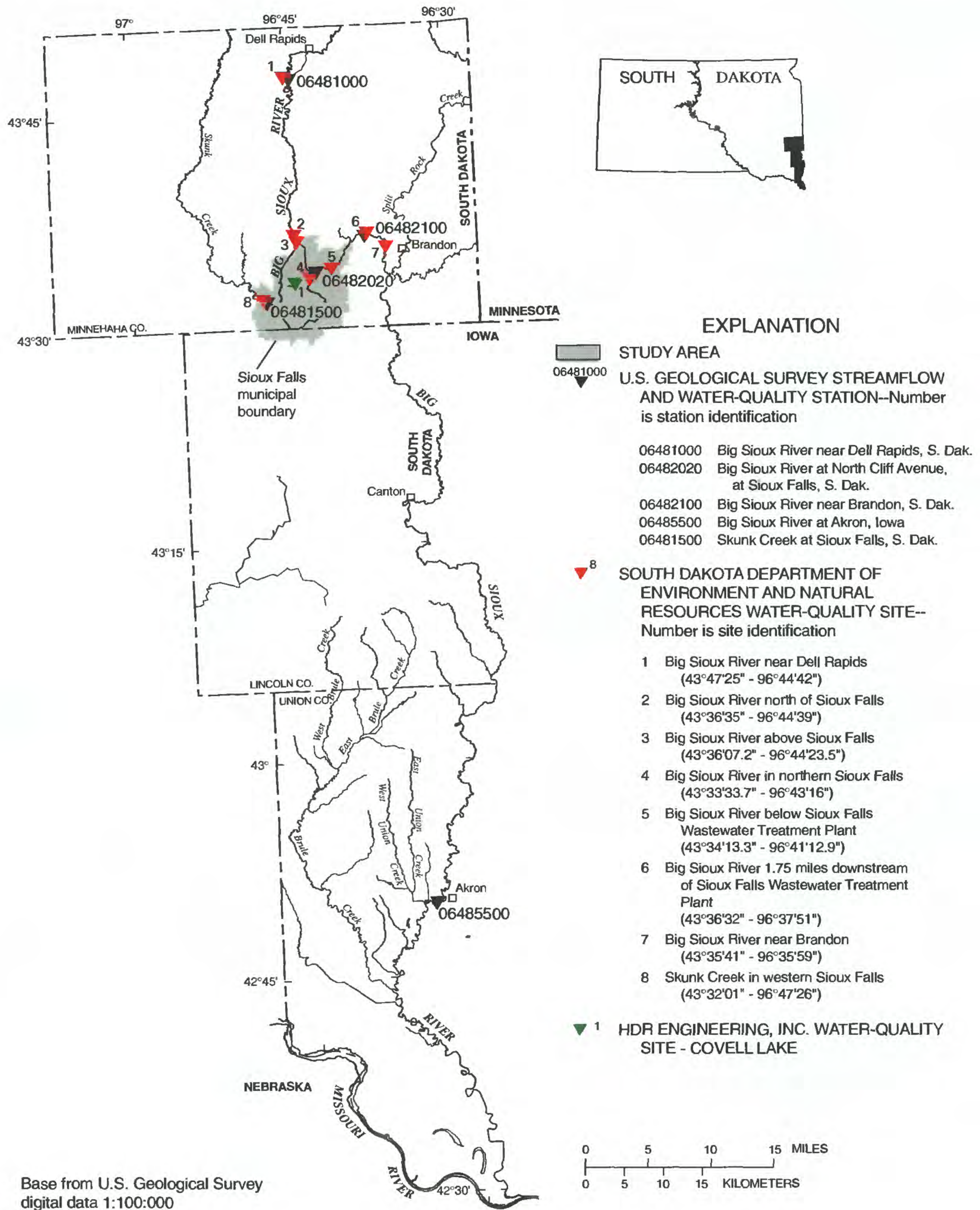

digital data 1:100:000

Figure 1. Locations of streamflow and water-quality sites within and near Sioux Falls. 
Table 1. Annual and monthly storm and precipitation characteristics for 1949-88 for Sioux Falls

[Based on data from National Oceanic and Atmospheric Administration (1949-88); only storms with volumes greater than 0.1 inch precipitation were used in computations; a 6-hour dry period was used to differentiate between storms. --, not calculated]

\begin{tabular}{|c|c|c|c|c|c|c|}
\hline \multirow[b]{2}{*}{ Month } & \multicolumn{4}{|c|}{ Mean storm characteristics } & \multicolumn{2}{|c|}{ Mean } \\
\hline & $\begin{array}{l}\text { Number of } \\
\text { events }\end{array}$ & $\begin{array}{l}\text { Volume } \\
\text { (inches) }\end{array}$ & $\begin{array}{c}\text { Duration }{ }^{1} \\
\text { (hours) }\end{array}$ & $\begin{array}{c}\text { Intensity } \\
\text { (inches per hour) }\end{array}$ & $\begin{array}{l}\text { Precipitation } \\
\text { (inches) }\end{array}$ & $\begin{array}{l}\text { Snowfal } \\
\text { (inches) }\end{array}$ \\
\hline January & 1.4 & $\begin{array}{c}0.29 \\
(0.15-0.44)\end{array}$ & $\begin{array}{c}15.5 \\
(7.8-23.3)\end{array}$ & 0.022 & 0.53 & 6.7 \\
\hline February & 1.6 & $\begin{array}{c}0.42 \\
(0.21-0.63)\end{array}$ & $\begin{array}{c}16.0 \\
(8.0-24.0)\end{array}$ & 0.026 & 0.77 & 8.1 \\
\hline March & 3.2 & $\begin{array}{c}0.48 \\
(0.24-0.72)\end{array}$ & $\begin{array}{l}15.7 \\
(7.9-23.6)\end{array}$ & 0.036 & 1.71 & 10.1 \\
\hline April & 4.3 & $\begin{array}{c}0.56 \\
(0.28-0.84)\end{array}$ & $\begin{array}{l}12.3 \\
(6.2-18.5)\end{array}$ & 0.057 & 2.43 & 2.4 \\
\hline May & 5.6 & $\begin{array}{c}0.51 \\
(0.26-0.77)\end{array}$ & $\begin{array}{c}8.5 \\
(4.3-12.8)\end{array}$ & 0.083 & 3.11 & 0.0 \\
\hline June & 6.3 & $\begin{array}{c}0.56 \\
(0.28-0.84)\end{array}$ & $\begin{array}{c}6.4 \\
(3.2-9.6)\end{array}$ & 0.12 & 3.65 & 0.0 \\
\hline July & 5.1 & $\begin{array}{c}0.50 \\
(0.25-0.75)\end{array}$ & $\begin{array}{c}4.5 \\
(2.3-8.0)\end{array}$ & 0.14 & 2.70 & 0.0 \\
\hline August & 5.2 & $\begin{array}{c}0.55 \\
(0.28-0.83)\end{array}$ & $\begin{array}{c}5.3 \\
(2.7-8.0)\end{array}$ & 0.14 & 3.00 & 0.0 \\
\hline September & 4.5 & $\begin{array}{c}0.64 \\
(0.32-0.96)\end{array}$ & $\begin{array}{c}8.6 \\
(4.3-12.9)\end{array}$ & 0.097 & 2.94 & 0.0 \\
\hline October & 2.6 & $\begin{array}{c}0.55 \\
(0.28-0.83)\end{array}$ & $\begin{array}{c}10.9 \\
(5.5-16.4)\end{array}$ & 0.059 & 1.62 & 0.5 \\
\hline November & 1.8 & $\begin{array}{c}0.51 \\
(0.26-0.77)\end{array}$ & $\begin{array}{c}16.0 \\
(8.0-24.0)\end{array}$ & 0.034 & 1.04 & 4.8 \\
\hline December & 1.8 & $\begin{array}{c}0.34 \\
(0.17-0.51)\end{array}$ & $\begin{array}{c}13.3 \\
(6.7-20.0)\end{array}$ & 0.027 & 0.72 & 7.8 \\
\hline Annual sum & 43.4 & -- & -- & -- & 24.22 & 40.4 \\
\hline Mean & -- & $\begin{array}{c}0.49 \\
(0.25-0.74)\end{array}$ & $\begin{array}{l}11.1 \\
(5.5-16.6)\end{array}$ & $\begin{array}{c}0.070 \\
1_{(0.035-0.105)}\end{array}$ & -- & -- \\
\hline
\end{tabular}

${ }^{1}$ Values in parentheses represent the range $(\bar{x}-\bar{x} / 2)$ to $(\bar{x}+\bar{x} / 2)$, where $\bar{x}=$ mean. 


\section{Land Use and Drainage Basins}

Land use and drainage-basin characteristics within and near Sioux Falls are shown in tables 2 and 3 and figures 2 and 3 . Areas of different land uses and drainage basins were determined using ARC/INFO (GIS) by combining attributes of different data layers. Twenty-nine drainage basins (drainage basin 29 is actually not one drainage basin, but a collection of four small areas that drain away from Sioux Falls) were delineated and digitized using the topography on 7.5-minute 1:24,000 USGS quadrangle maps. Existing studies done for Sioux Falls also were used as an aid in delineating the drainage basins (DeWild and others, 1979, 1986, 1987, 1990, 1992a, 1992b; HDR Engineering, Inc., 1994; JSA Engineers and Land Surveyors, Inc., 1989, 1990a, 1990b, 1993, 1994, 1995; and R.F. Sayre and Associates, 1986, 1991).

Drainage basin 29 includes a number of small, unconnected drainage basins that total 237 acres. These unconnected drainage basins were not each assigned a unique number because of their small size and because they all drain away from Sioux Falls before reaching receiving waters.

The municipal boundary of Sioux Falls encompasses about 48.5 square miles. The predominant land use within the City boundary is residential, covering about 21.2 square miles or 43.6 percent of the total municipal area. Over 70 percent of the municipal area is developed (commercial, industrial, or residential).

The delineated drainage basins encompass 67.1 square miles within and near the City. The predominant land uses of these basins are agricultural and nonclassified (covering 25.2 square miles or 37.5 percent of the total), which includes water and interstate highway rights of way, and residential (covering 22.5 square miles or 33.5 percent of the total). Over 54 percent of the area within the delineated drainage basins is developed (commercial, industrial, or residential).

Table 2. Land-use classification within and near Sioux Falls

[Nonclassified includes water and interstate highway rights of way]

\begin{tabular}{|c|c|c|c|c|c|c|}
\hline \multirow[b]{2}{*}{ Land use } & \multicolumn{3}{|c|}{ Area within the City } & \multicolumn{3}{|c|}{$\begin{array}{l}\text { Drainage-basin area delineated within } \\
\text { and near the City }{ }^{1}\end{array}$} \\
\hline & (square miles) & (acres) $^{2}$ & $\begin{array}{c}\text { Percent } \\
\text { of total } \\
\text { area }\end{array}$ & (square miles) & (acres) $^{2}$ & $\begin{array}{l}\text { Percent of total } \\
\text { delineated area }\end{array}$ \\
\hline Commercial & 7.5 & 4,821 & 15.6 & 7.5 & 4,806 & 11.2 \\
\hline Industrial & 6.0 & 3,825 & 12.3 & 6.4 & 4,105 & 9.6 \\
\hline Residential & 21.2 & 13,539 & 43.6 & 22.5 & 14,410 & 33.5 \\
\hline $\begin{array}{l}\text { Agricultural and } \\
\text { nonclassified }\end{array}$ & 8.0 & 5,133 & 16.5 & 25.2 & 16,121 & 37.5 \\
\hline $\begin{array}{l}\text { Parks and } \\
\text { recreational }\end{array}$ & 5.4 & 3,444 & 11.1 & 5.1 & 3,272 & 7.6 \\
\hline $\begin{array}{l}\text { Planned } \\
\text { residential or } \\
\text { industrial }\end{array}$ & 0.4 & 275 & 0.9 & 0.4 & 275 & 0.6 \\
\hline Total & 48.5 & 31,037 & 100.0 & 67.1 & 42,989 & 100.0 \\
\hline
\end{tabular}

${ }^{1}$ Drainage-basin areas do not include Big Sioux River and Skunk Creek waterways within and near the City.

${ }^{2}$ Acre values were computed before square-mile values were rounded. 
Table 3. Drainage basins within and near Sioux Falls

[Land use group: 1, commercial; 2 , industrial; 3, residential; 4, agricultural and nonclassified; 5 , parks and recreational; 6, planned residential or industrial]

\begin{tabular}{|c|c|c|c|c|c|c|}
\hline $\begin{array}{c}\text { Drainage } \\
\text { basin }\end{array}$ & $\begin{array}{l}\text { Land-use } \\
\text { group }\end{array}$ & \multicolumn{2}{|c|}{$\begin{array}{l}\text { Area of land-use group in } \\
\text { drainage basin }\end{array}$} & \multicolumn{2}{|c|}{ Total area per drainage basin } & $\begin{array}{l}\text { Percent of total } \\
\text { drainage-basin area } \\
\text { per land-use group }\end{array}$ \\
\hline \multirow[t]{3}{*}{1} & 3 & 394 & 0.62 & & & 18.5 \\
\hline & 5 & 18 & 0.03 & & & 0.8 \\
\hline & & & & 2,137 & 3.34 & \\
\hline \multirow{4}{*}{2} & 4 & 3,264 & 5.10 & & & 52.4 \\
\hline & 5 & 197 & 0.31 & & & 3.2 \\
\hline & 6 & 275 & 0.43 & & & 4.4 \\
\hline & & & & 6,231 & 9.74 & \\
\hline \multirow[t]{2}{*}{3} & 1 & 26 & 0.04 & & & 6.7 \\
\hline & & & & 381 & 0.60 & \\
\hline \multirow[t]{5}{*}{4} & 1 & 1 & 0.00 & & & 0.1 \\
\hline & 3 & 264 & 0.41 & & & 14.0 \\
\hline & 4 & 1,599 & 2.50 & & & 84.7 \\
\hline & 5 & 23 & 0.04 & & & 1.2 \\
\hline & & & & 1,887 & 2.95 & \\
\hline \multirow[t]{4}{*}{5} & 3 & 18 & 0.03 & & & 54.9 \\
\hline & 4 & 2 & 0.00 & & & 7.1 \\
\hline & 5 & 13 & 0.02 & & & 38.0 \\
\hline & & & & 33 & 0.05 & \\
\hline 6 & 4 & 9 & 0.01 & & & 47.2 \\
\hline \multirow{2}{*}{7} & 5 & 354 & 0.55 & & & 13.7 \\
\hline & & & & 2,579 & 4.02 & \\
\hline \multirow[t]{4}{*}{8} & 1 & ${ }^{2} 0$ & 0.00 & & & 0.4 \\
\hline & 2 & 53 & 0.08 & & & 82.0 \\
\hline & 4 & 11 & 0.02 & & & 17.6 \\
\hline & & & & 64 & 0.10 & \\
\hline \multirow[t]{5}{*}{10} & 2 & 72 & 0.11 & & & 6.0 \\
\hline & 3 & 29 & 0.05 & & & 2.4 \\
\hline & 4 & 1,085 & 1.70 & & & 90.9 \\
\hline & 5 & 8 & 0.01 & & & 0.7 \\
\hline & & & & 1,194 & 1.87 & \\
\hline \multirow[t]{6}{*}{11} & 1 & 73 & 0.11 & & & 18.2 \\
\hline & 2 & 214 & 0.34 & & & 53.6 \\
\hline & 3 & 9 & 0.02 & & & 2.3 \\
\hline & 4 & 98 & 0.15 & & & 24.5 \\
\hline & 5 & 6 & 0.01 & & & 1.4 \\
\hline & & & & 400 & 0.63 & \\
\hline
\end{tabular}


Table 3. Drainage basins within and near Sioux Falls-Continued

\begin{tabular}{|c|c|c|c|c|c|c|}
\hline \multirow{2}{*}{$\begin{array}{l}\text { Drainage } \\
\text { basin }\end{array}$} & \multirow{2}{*}{$\begin{array}{l}\text { Land-use } \\
\text { group }\end{array}$} & \multicolumn{2}{|c|}{$\begin{array}{l}\text { Area of land-use group in } \\
\text { drainage basin }\end{array}$} & \multicolumn{2}{|c|}{ Total area per drainage basin } & \multirow{2}{*}{$\begin{array}{l}\text { Percent of total } \\
\text { drainage-basin area } \\
\text { per land-use group }\end{array}$} \\
\hline & & (acres) & (square miles) & (acres) & (square miles) & \\
\hline \multirow[t]{5}{*}{12} & 1 & 44 & 0.07 & & & 2.6 \\
\hline & 3 & 1,261 & 1.97 & & & 74.5 \\
\hline & 4 & 195 & 0.30 & & & 11.5 \\
\hline & 5 & 192 & 0.30 & & & 11.4 \\
\hline & & & & 1,692 & 2.64 & \\
\hline \multirow[t]{5}{*}{13} & 1 & 20 & 0.03 & & & 1.1 \\
\hline & 3 & 1,452 & 2.27 & & & 80.2 \\
\hline & 4 & 279 & 0.44 & & & 15.4 \\
\hline & 5 & 59 & 0.09 & & & 3.3 \\
\hline & & & & 1,810 & 2.83 & \\
\hline \multirow[t]{5}{*}{14} & 1 & 4 & 0.01 & & & 0.2 \\
\hline & 3 & 292 & 0.45 & & & 12.5 \\
\hline & 4 & 2,036 & 3.18 & & & 87.0 \\
\hline & 5 & 7 & 0.01 & & & 0.3 \\
\hline & & & & 2,339 & 3.65 & \\
\hline \multirow[t]{5}{*}{15} & 1 & 6 & 0.01 & & & 0.9 \\
\hline & 3 & 595 & 0.93 & & & 92.3 \\
\hline & 4 & 32 & 0.05 & & & 5.0 \\
\hline & 5 & 12 & 0.02 & & & 1.8 \\
\hline & & & & 645 & 1.01 & \\
\hline \multirow[t]{5}{*}{16} & 1 & 9 & 0.01 & & & 2.5 \\
\hline & 3 & 238 & 0.37 & & & 70.9 \\
\hline & 4 & 89 & 0.14 & & & 26.6 \\
\hline & 5 & ${ }^{2} 0$ & 0.00 & & & 0.0 \\
\hline & & & & 336 & 0.52 & \\
\hline \multirow[t]{5}{*}{17} & 1 & 1 & 0.00 & & & 0.1 \\
\hline & 3 & 227 & 0.35 & & & 17.2 \\
\hline & 4 & 1,082 & 1.69 & & & 81.9 \\
\hline & 5 & 11 & 0.02 & & & 0.8 \\
\hline & & & & 1,321 & 2.06 & \\
\hline \multirow[t]{5}{*}{18} & 1 & 21 & 0.03 & & & 5.2 \\
\hline & 3 & 357 & 0.56 & & & 90.7 \\
\hline & 4 & 5 & 0.01 & & & 1.2 \\
\hline & 5 & 11 & 0.02 & & & 2.9 \\
\hline & & & & 394 & 0.62 & \\
\hline \multirow[t]{6}{*}{19} & 1 & 482 & 0.75 & & & 13.5 \\
\hline & 2 & 394 & 0.62 & & & 11.0 \\
\hline & 3 & 1,987 & 3.11 & & & 55.7 \\
\hline & 4 & 355 & 0.55 & & & 10.0 \\
\hline & 5 & 348 & 0.54 & & & 9.8 \\
\hline & & & & 3,566 & 5.57 & \\
\hline \multirow[t]{5}{*}{20} & 2 & 67 & 0.10 & & & 3.4 \\
\hline & 3 & 337 & 0.53 & & & 17.0 \\
\hline & 4 & 1,255 & 1.96 & & & 63.3 \\
\hline & 5 & 323 & 0.51 & & & 16.3 \\
\hline & & & & 1,982 & 3.10 & \\
\hline \multirow[t]{6}{*}{21} & 1 & 294 & 0.46 & & & 14.4 \\
\hline & 2 & 1,182 & 1.85 & & & 57.7 \\
\hline & 3 & 250 & 0.39 & & & 12.2 \\
\hline & 4 & 264 & 0.41 & & & 12.9 \\
\hline & 5 & 58 & 0.09 & & & 2.8 \\
\hline & & & & 2,048 & 3.20 & \\
\hline
\end{tabular}


Table 3. Drainage basins within and near Sioux Falls-Continued

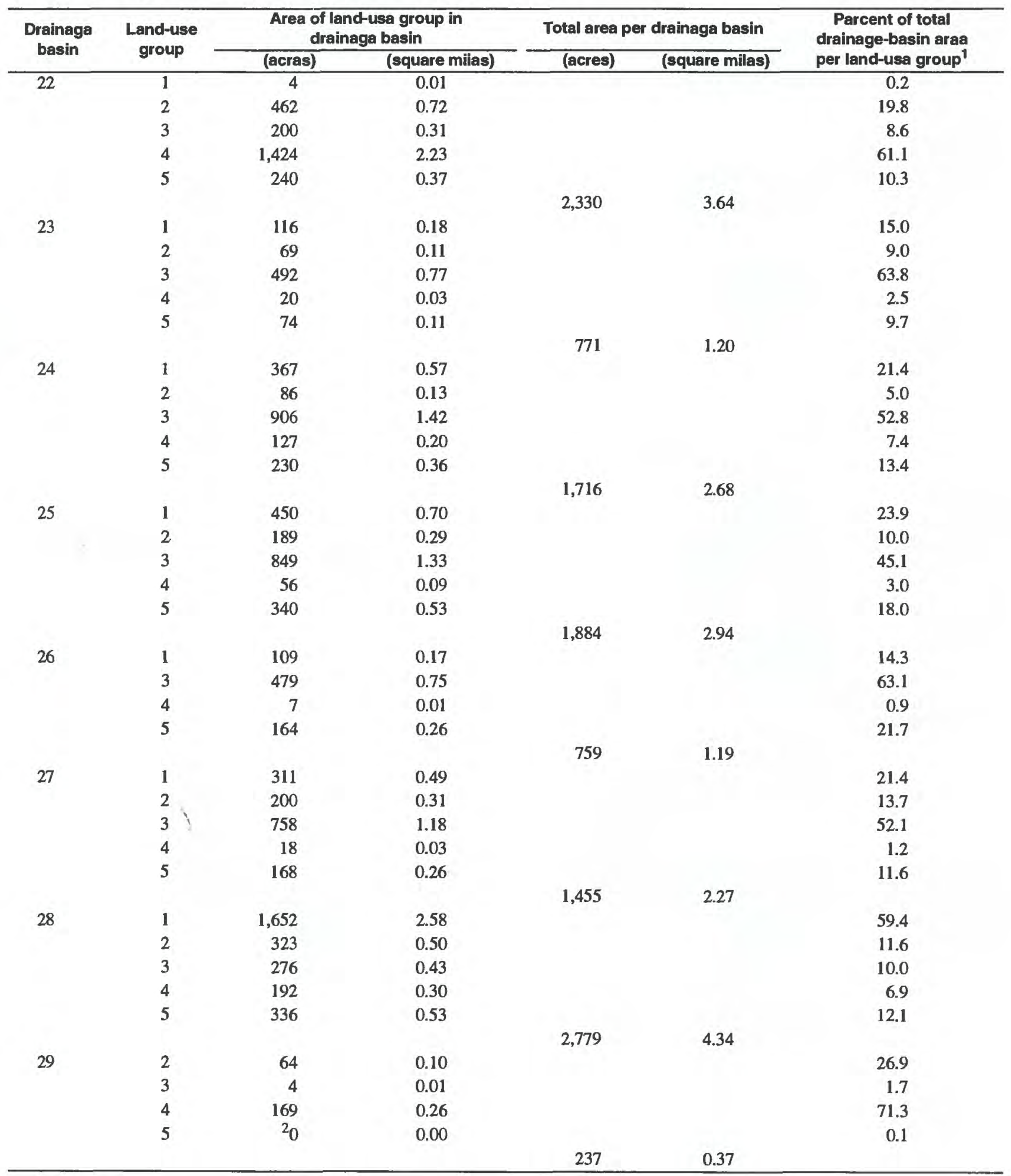

${ }^{1}$ Percent values were computed before drainage-basin values were rounded.

${ }^{2}$ Area less than 1 acre. 

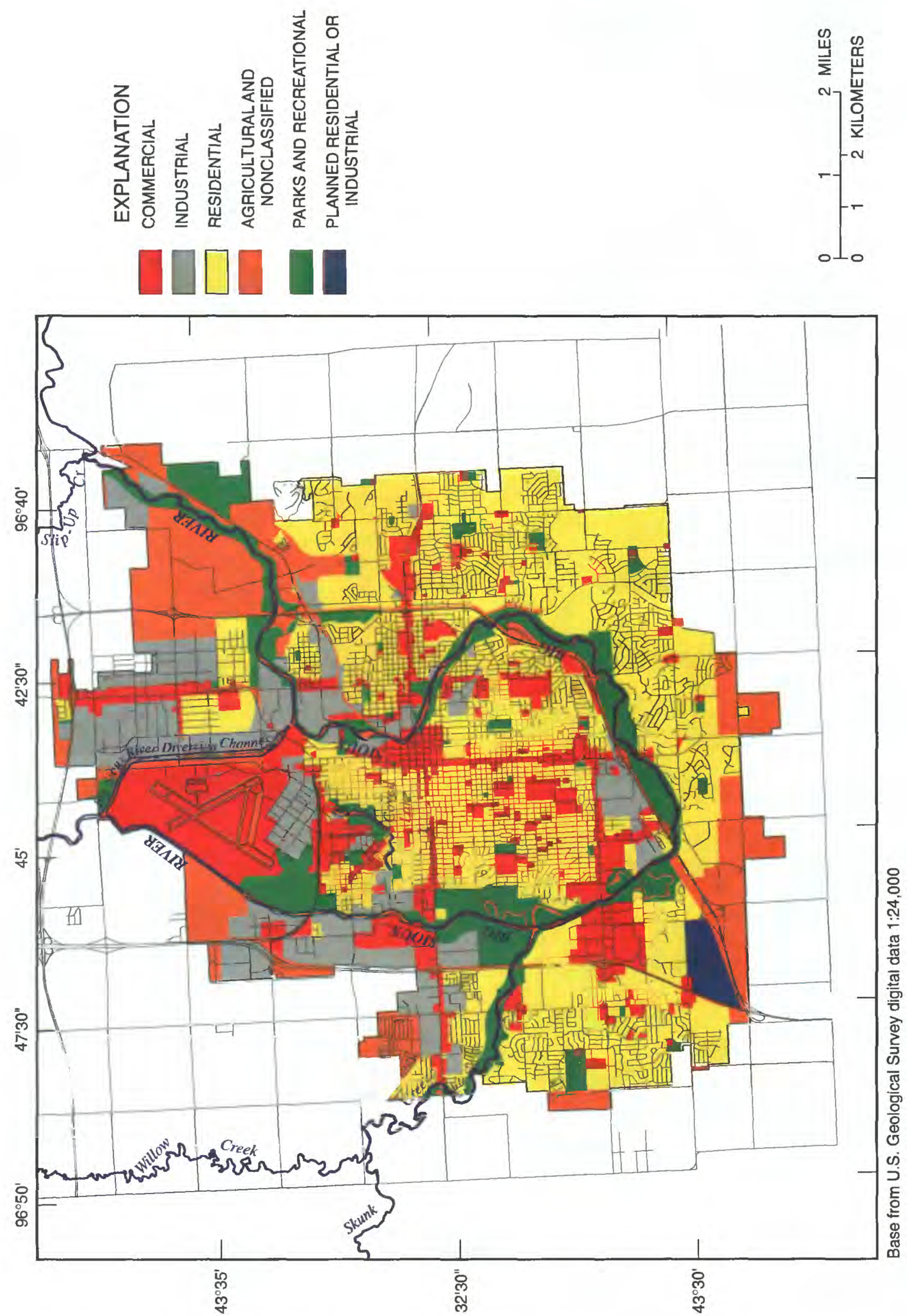

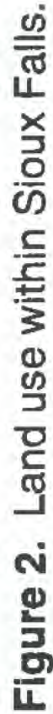



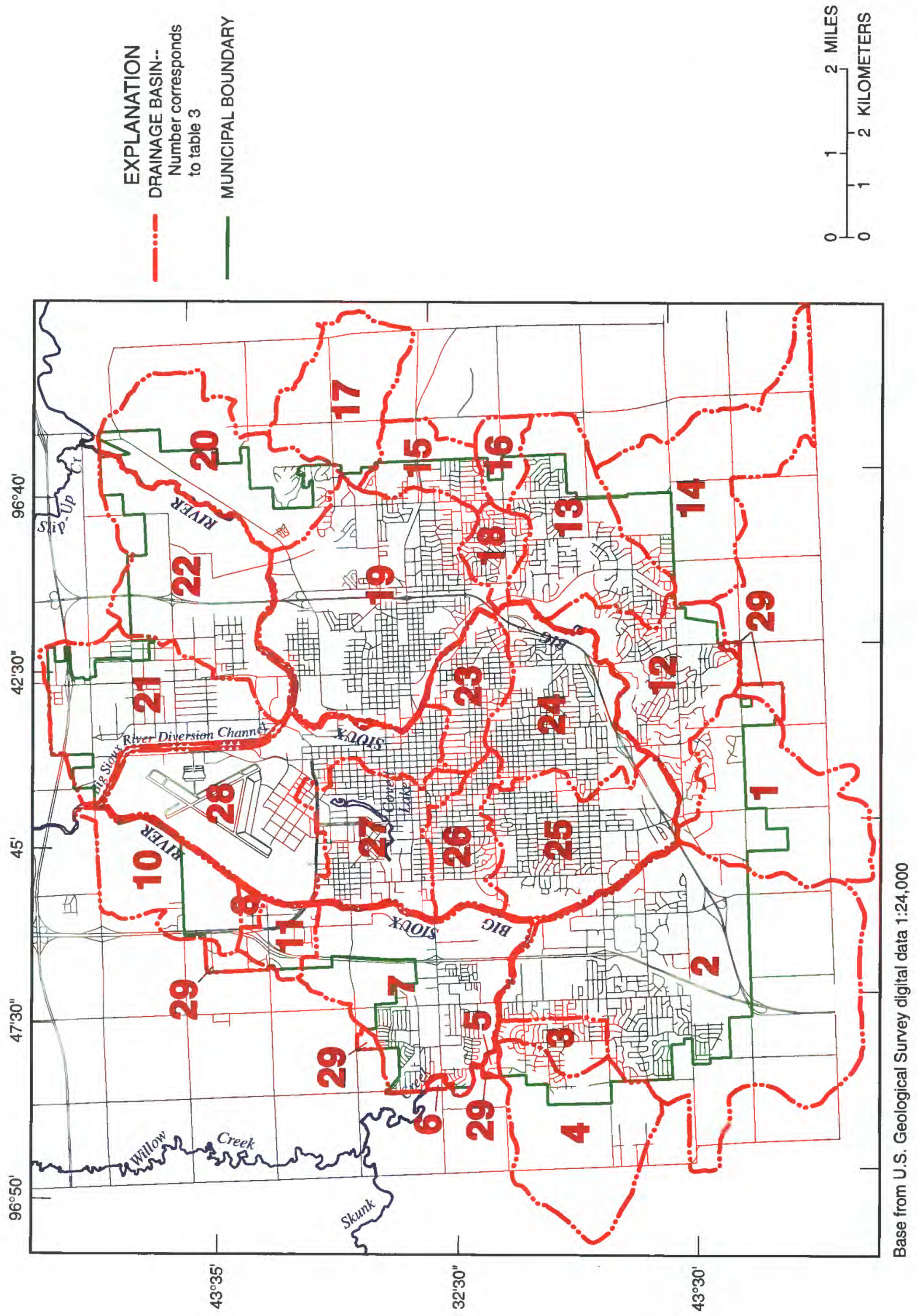

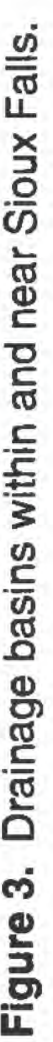




\section{Surface Water}

There are two major streams and one major lake that receive discharge from the Sioux Falls stormwater system. These are the Big Sioux River, Skunk Creek, and Covell Lake (fig. 3).

\section{Flow}

Flow in the Big Sioux River and Skunk Creek generally is seasonal, with the highest flows occurring in late spring and early summer. The months when the prominent peaks generally occur at streamflow-gaging stations on these two streams will depend on the period of record of the gaging station. The Big Sioux River Diversion Channel in northern Sioux Falls helps protect the City from flooding by bypassing Big Sioux River flood flows.

Streamflow-gaging stations operated by the USGS within and near Sioux Falls and at Akron, Iowa (shown in fig. 1), are as follows:

06481000 Big Sioux River near Dell Rapids, S. Dak.

06482020 Big Sioux River at North Cliff Avenue, at Sioux Falls, S. Dak.

06482100 Big Sioux River near Brandon, S. Dak.

06485500 Big Sioux River at Akron, Iowa 06481500 Skunk Creek at Sioux Falls, S. Dak.

The Big Sioux River near Dell Rapids station is about 19 miles upstream of Sioux Falls and has a drainage area of 4,483 square miles. The average discharge for 43 years (1949-91) at this station is 317 cubic feet per second. Prominent peaks in average daily flow generally occur in early April, late June, and late September.

The Big Sioux River at North Cliff Avenue, at Sioux Falls station has a drainage area of 5,216 square miles. The average discharge for 20 years (1972-91) at this station is 490 cubic feet per second. Prominent peaks in average daily flow generally occur in late March and early April, late June, and late September.

The Big Sioux River near Brandon station is about 2 miles downstream of Sioux Falls and has a drainage area of 5,810 square miles. The average discharge for 13 years (1960-72) at this station is 361 cubic feet per second. Prominent peaks in average daily flow generally occur in early April.

The Big Sioux River at Akron, Iowa, station is about 96 miles downstream of Sioux Falls and has a drainage area of 8,424 square miles. The average discharge for 63 years (1929-91) at this station is 1,010 cubic feet per second. Prominent peaks in average daily flow generally occur in early April and late June.

The Skunk Creek at Sioux Falls station has a drainage area of 622 square miles. The average discharge for 43 years (1949-91) at this station is 66.5 cubic feet per second. Prominent peaks in average daily flow generally occur in late March and early April, late June, and late September.

\section{Water Quality}

The Big Sioux River (from headwater to mouth) is included on the 1993 list of the 25 priority rivers in the South Dakota Nonpoint-Source Program (South Dakota Department of Environment and Natural Resources, 1993). The primary focus of this program is to reduce negative water-quality impacts that result from nonpoint pollutant sources on South Dakota lakes and streams. The prioritization of the Big Sioux River, one of the primary receiving waters of Sioux Falls stormwater runoff, in the South Dakota Nonpoint Source Program further indicates the relevance of the study of Sioux Falls stormwater runoff effects to waterquality issues in South Dakota.

Prior to this study, only a small amount of data has been collected relative to discharges from the Sioux Falls stormwater system. However, the USGS has collected water-quality data in the major receiving streams (the Big Sioux River and Skunk Creek) at, upstream, and downstream of Sioux Falls (the same five stations previously discussed, fig. 1). Analytical results are documented in a series of annual reports by the USGS entitled Water Resources Data for South Dakota (U.S. Geological Survey, 1974-96).

Boxplots showing the distribution of selected chemical analyses of water from USGS streamflowgaging stations within and near Sioux Falls are presented in figure 4. Boxplots graphically summarize data and show whether the data are symmetrically distributed or skewed. In a boxplot diagram, the box represents the interquartile range (25th to 75 th percentile) with the horizontal line within the box representing the median. A step is 1.5 times the interquartile range. Data points between one and two steps from the box in either direction are called "outside points." Data points farther than two steps beyond the box are called "far outside points." Additional water-quality data are reported in the above-cited USGS data reports. 
HDR Engineering, Inc. also has collected waterquality data for Covell Lake (fig. 1) as part of a basin study (HDR Engineering, Inc., 1993), which was done to assist the City of Sioux Falls in collection of baseline water-quality data for the purpose of assessing the current trophic status of the lake. Samples from the lake, which receives stormwater-system runoff from Sioux Falls, were collected in the spring and summer of 1992.

The South Dakota Department of Environment and Natural Resources (SDDENR) has collected water-quality data at seven sites on the Big Sioux River and at one site on Skunk Creek near Sioux Falls (fig. 1). Sample information including the sampling procedures, analyses done, and analytical methods used are documented in a 305(b) Water Quality Assessment report (South Dakota Department of Environment and Natural Resources, 1992). Data on the sampled waterquality constituents are on file at SDDENR.

The 305(b) report (South Dakota Department of Environment and Natural Resources, 1992) was compiled to fulfill the Federal Clean Water Act reporting requirements. A summary of information on the Big
Sioux River, Skunk Creek, and Covell Lake, which are listed in the 305(b) report, is shown in table 4. According to this report, urban stormwater runoff has a moderate effect on the Big Sioux River from the Big Sioux River Diversion Channel to 3 miles east of Canton. Urban stormwater runoff has had a significant effect on Covell Lake, which is eutrophic due mainly to its high nutrient enrichment and siltation. The lakes in the Big Sioux River Basin are all eutrophic to varying degrees due to algae, nutrient enrichment, and siltation. This is expected to continue in the future because of the relatively small size and shallow depth of the lakes. The characteristics of Covell Lake differ from the typical lake in this basin by having no algae problem and by having the major source of its impaired uses due to urban runoff as contrast to the typical lake's impaired uses due to agriculture runoff and septic-tank leakage. Much of the Big Sioux River is not supporting its fishable/swimmable beneficial uses, which in Sioux Falls is due in large part to the high fecal coliform numbers and suspended solids. Skunk Creek near Sioux Falls is supporting its beneficial uses.

Table 4. Characteristics of the Big Sioux River, Skunk Creek, and Covell Lake within and near Sioux Falls

[From South Dakota Department of Environment and Natural Resources (1992). --, not classified]

\begin{tabular}{|c|c|c|c|c|c|c|}
\hline Water body & Reach & $\begin{array}{l}\text { Fishable/ } \\
\text { swimmable }\end{array}$ & Causes of nonsupport & Source categories & Trend & $\begin{array}{l}\text { Trophic } \\
\text { status }\end{array}$ \\
\hline $\begin{array}{l}\text { Big Sioux } \\
\text { River }\end{array}$ & $\begin{array}{l}\text { Above Dell Rapids to } \\
\text { Sioux Falls Diversion } \\
\text { Channel - } 42 \text { miles }\end{array}$ & Nonsupported & $\begin{array}{l}\text { Organic enrichment } \\
\text { (slight) } \\
\text { pH (slight) } \\
\text { Suspended solids } \\
\text { (moderate) } \\
\text { Pathogens (slight) } \\
\text { Salinity/dissolved } \\
\text { solids/chlorides } \\
\text { (slight) }\end{array}$ & $\begin{array}{l}\text { Non-irrigated crop production } \\
\text { (moderate) } \\
\text { Pasture land (moderate) } \\
\text { Feedlots-all types (moderate) } \\
\text { Animal holding/management } \\
\text { areas (moderate) }\end{array}$ & Degrading & -- \\
\hline $\begin{array}{l}\text { Big Sioux } \\
\text { River }\end{array}$ & $\begin{array}{l}\text { Sioux Falls Diversion } \\
\text { Channel to } 3 \text { miles east } \\
\text { of Canton - } 30 \text { miles }\end{array}$ & Nonsupported & $\begin{array}{l}\text { Suspended solids (high) } \\
\text { pH (moderate) } \\
\text { Pathogens (high) } \\
\text { Ammonia (slight) } \\
\text { Organic enrichment } \\
\quad \text { (slight) }\end{array}$ & $\begin{array}{l}\text { Natural (moderate) } \\
\text { Non-irrigated crop production } \\
\text { (high) } \\
\text { Pasture land (moderate) } \\
\text { Feedlots-all types (high) } \\
\text { Urban storm sewers (moderate) } \\
\text { Urban surface runoff } \\
\text { (moderate) } \\
\text { Streambank modification/ } \\
\text { destabilization (moderate) }\end{array}$ & Stable & -- \\
\hline Skunk Creek & $\begin{array}{l}\text { Headwaters to mouth - } \\
50 \text { miles }\end{array}$ & Supported & -- & -- & - & -- \\
\hline Covell Lake & Sioux Falls & Nonsupported & $\begin{array}{l}\text { Nutrients (high) } \\
\text { Siltation (high) } \\
\text { Chlorine (moderate) } \\
\text { Oil and grease } \\
\quad \text { (moderate) }\end{array}$ & Urban surface runoff (high) & Unknown & Eutrophic \\
\hline
\end{tabular}



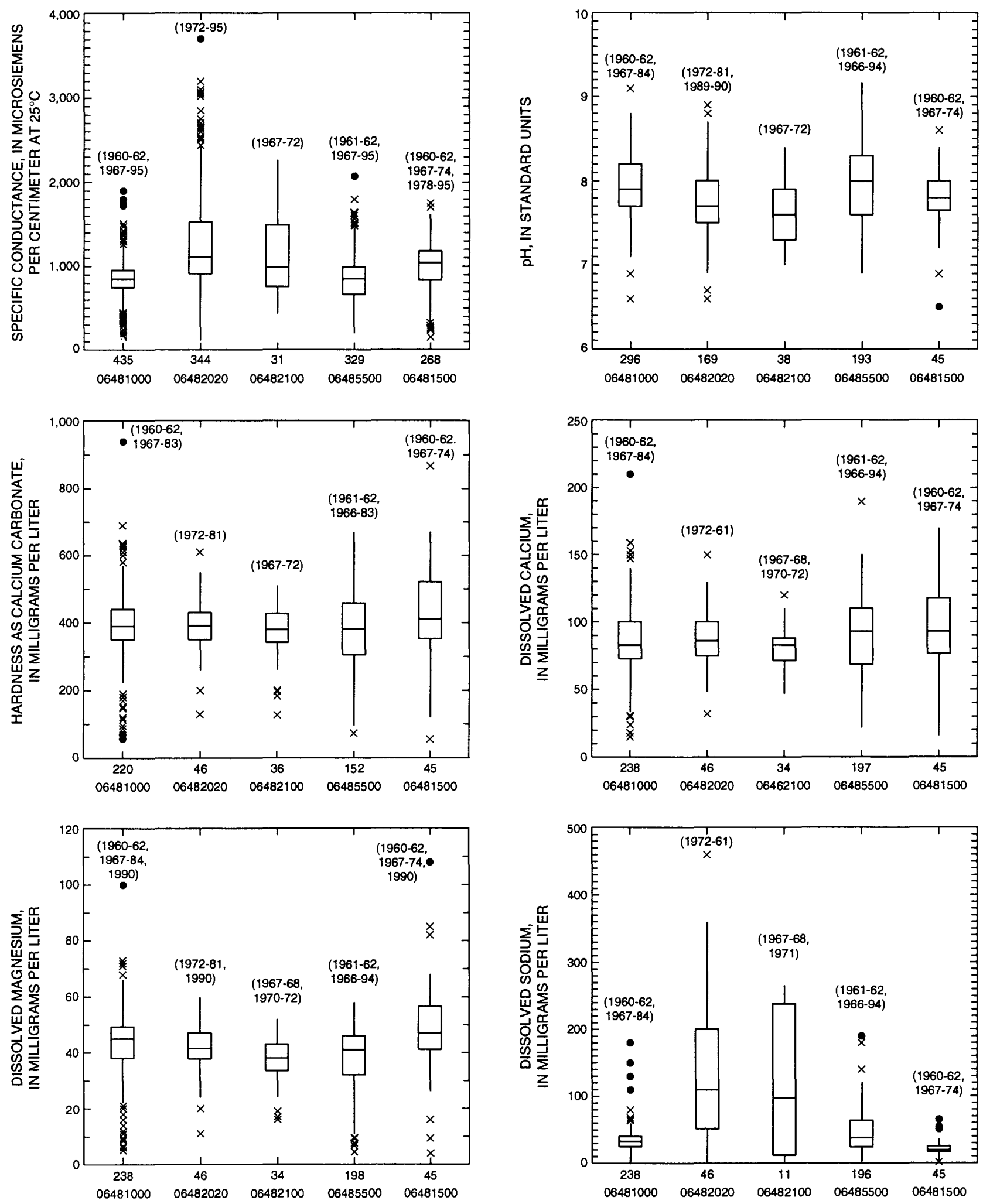

Figure 4. Distritution of selected chemical analyses of water from selected U.S. Geological Survey streamflow-gaging stations within and near Sioux Falls. 

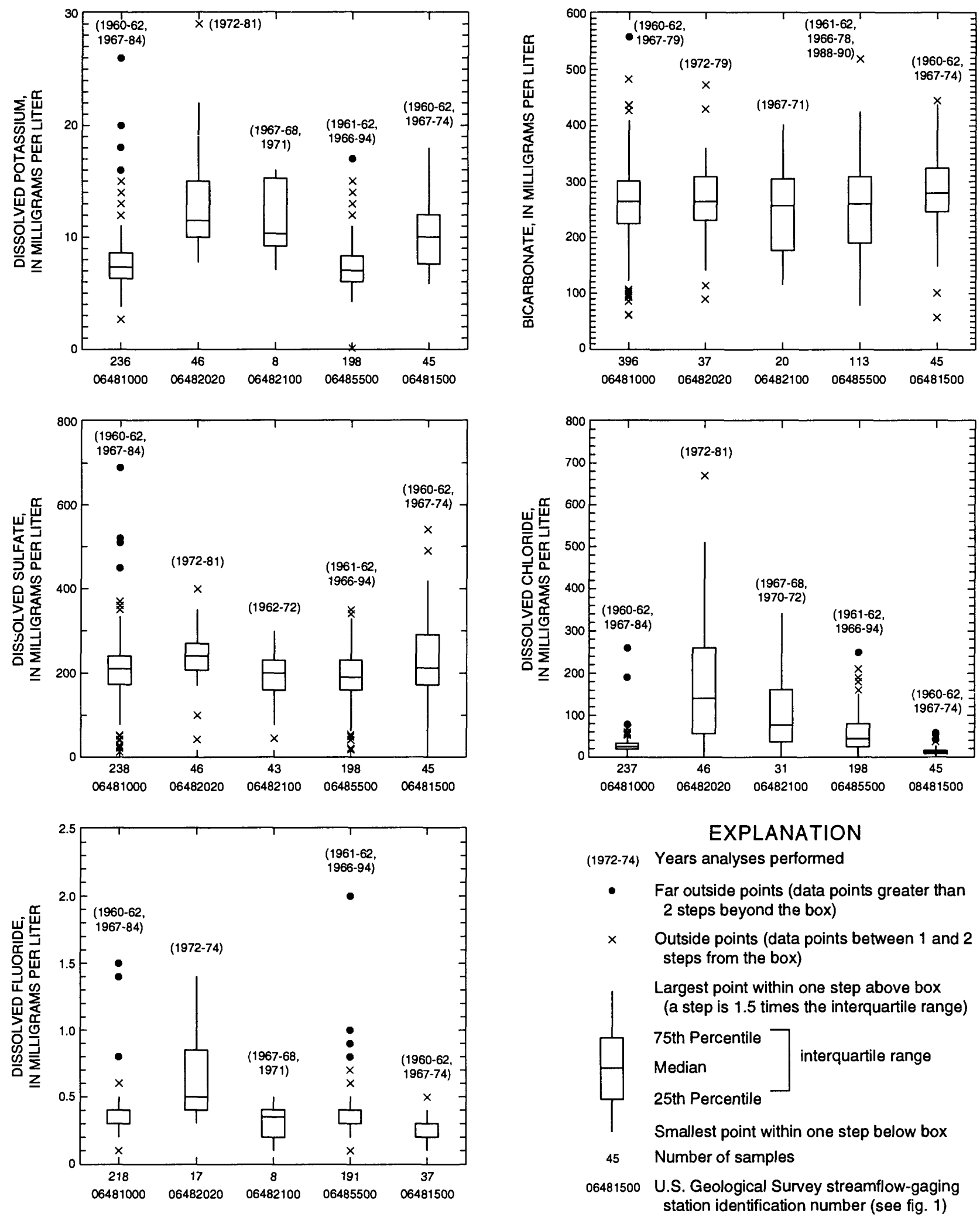

Figure 4. Distribution of selected chemical analyses of water from selected U.S. Geological Survey streamflow-gaging stations within and near Sioux Falls.--Continued 


\section{METHODS OF INVESTIGATION}

Stormwater-runoff samples were collected from three sites considered representative of the major land uses in Sioux Falls (commercial, industrial, and residential). At each sampling site, stage, discharge, rainfall, and water-quality samples were measured and/or collected during four representative storms occurring at least one month apart. Runoff from storms was sampled only if preceded by at least 72 hours of dry weather (less than 0.1 inch of rainfall).

\section{Site Selection and Land Characteristics}

\section{Criteria used to select the sampling sites} included hydraulics, safety, runoff representativeness, land-use representativeness, and accessibility. The sampling sites were selected in consultation with personnel of the City of Sioux Falls.

Hydraulic factors were important in choosing the sampling sites. An open-channel site must be located where an accurate stage-discharge relationship can be established and where stage and discharge can be measured accurately. Therefore, the sampling sites must be located where the channels have adequate hydraulic control, are relatively uniform, and are relatively stable (negligible degradation or aggradation). These factors also are important if any weirs or flumes are placed in the channel to assist in discharge measurement and stage-discharge rating curve establishment. The site locations also were selected where there were no major ponding effects in the channels to avoid concentration of constituents.

Safety was important in choosing the sites both for accident prevention and for quality control. In order to obtain accurate results, the data had to be collected in an unhurried and organized manner without risk of injury. Confined sites were avoided both because of increased risk of injury and because of the increased time required to collect data due to the additional confined-space safety requirements. Areas of high traffic where lack of light and/or visibility create conditions conducive to accidents or injuries also were avoided.

The sampling sites were chosen so that they were representative of the stormwater runoff found throughout Sioux Falls. Thus, the sites that were selected represent the major land uses found in Sioux Falls (commercial, industrial, and residential). It is not appropriate to collect data and apply it to all of the outfalls if the conditions at the sampling sites are unique.
Accessibility of the monitoring sites also was important. The samples had to be collected, preserved, and analyzed according to a specific time schedule. The sampling crews had to be able to conveniently transport their sampling equipment to the location of the site to collect and process the required samples in a timely manner.

A summary of the characteristics of land uses and drainage basins of the sampling sites is shown in table 5. Commercial, industrial, and residential land uses represent 71.5 percent of the total land use in the City and 100 percent of the developed land. Little additional information could have been gained by sampling for other land uses. The other land-use categories (agricultural and nonclassified, planned residential or commercial, and parks and recreation) have less potential for water-quality effects than do the developed (residential, commercial, and industrial) land uses. The locations of the sampling sites are shown in figure 5 .

Site 1, representative of commercial land use, is located at the southwest edge of Sioux Falls near the intersection of Interstate 29, 41 st Street, and the Big Sioux River. The sampling site is in an open channel upstream of two 72-inch culverts that drain into the Big Sioux River immediately east of the site. More than 70 percent of the drainage basin upstream of this waterquality sampling site is developed as commercial land use. The remainder of the upstream drainage basin is classified as residential (25.9 percent), parks and recreation (3.6 percent), and agricultural and nonclassified ( 0.3 percent). The drainage area upstream of this site is 0.23 square mile, which although small, provided an adequate amount of water for sampling during storm events. The majority of the land use is composed of general commercial (not heavy commercial). Much of the drainage area is composed of parking lots, which produced a large amount of runoff to the sampling site. The site has little traffic and is readily accessible from Louise Avenue. The site is a good location for sampling because of the uniform channel with only a slight problem created by small trees and heavy vegetation in the channel. A concrete weir was constructed across the open channel to provide hydraulic control and to pond the water slightly during storm events. Ponding of the runoff, which was necessary to provide adequate depth of water to sample, was kept to a minimum to avoid concentration of constituents. Most of the other potential sampling sites for commercial land use were determined not to be adequate sites due to the high percentage of residential land use within the same drainage basins. 
Table 5. Characteristics of larıd uses and drairlage basins of urban stormwater-runoff sampling sites within Sioux Falls

[Land use group: 1, commercial; 2, industrial; 3, residential; 4, agricultural and nonclassified; 5, parks and recreational]

\begin{tabular}{|c|c|c|c|c|c|c|c|}
\hline \multirow{2}{*}{$\begin{array}{l}\text { Sampling site } \\
\text { reference } \\
\text { number }\end{array}$} & \multirow{2}{*}{$\begin{array}{l}\text { Land-use } \\
\text { group }\end{array}$} & \multicolumn{2}{|c|}{ Area of land-use group } & \multicolumn{2}{|c|}{$\begin{array}{l}\text { Total area per } \\
\text { sampling site }\end{array}$} & \multirow{2}{*}{$\begin{array}{l}\text { Percent of total } \\
\text { dralnage-basin } \\
\text { area per land- } \\
\text { use group }{ }^{1}\end{array}$} & \multirow{2}{*}{$\begin{array}{l}\text { Predominant } \\
\text { land use }\end{array}$} \\
\hline & & (acres) & (square miles) & (acres) & (square miles) & & \\
\hline \multirow[t]{4}{*}{1} & 1 & 102 & 0.16 & 145 & 0.23 & 70.2 & Commercial \\
\hline & 3 & 37.5 & 0.06 & & & 25.9 & \\
\hline & 4 & 0.5 & 0.001 & & & 0.3 & \\
\hline & 5 & 5 & 0.01 & & & 3.6 & \\
\hline \multirow[t]{5}{*}{2} & 1 & 179 & 0.28 & 695 & 1.09 & 25.8 & Industrial \\
\hline & 2 & 427 & 0.67 & & & 61.5 & \\
\hline & 3 & 83 & 0.13 & & & 11.9 & \\
\hline & 4 & 3 & 0.005 & & & 0.4 & \\
\hline & 5 & 3 & 0.005 & & & 0.4 & \\
\hline \multirow[t]{3}{*}{3} & 1 & 21 & 0.03 & 328 & 0.51 & 6.5 & Residential \\
\hline & 3 & 250 & 0.39 & & & 76.1 & \\
\hline & 5 & 57 & 0.09 & & & 17.4 & \\
\hline
\end{tabular}

${ }^{\mathrm{l}}$ Percent values were computed before area values of land-use groups were rounded.

Site 2 , representative of industrial land use, is located at the north-central edge of Sioux Falls near the intersection of the Big Sioux River Diversion Channel and Benson Road and drains the largest industrial area of Sioux Falls. The sampling site is in an open channel upstream of two 48-inch culverts that drain into the Big Sioux River Diversion Channel, which is about 800 feet west of the site. More than 61 percent of the drainage basin upstream of the sampling site is developed as industrial land use. The remainder of the upstream drainage basin is classified as commercial 25.8 percent), residential (11.9 percent), parks and recreation ( 0.4 percent), and agricultural and nonclassified ( 0.4 percent). The drainage area upstream of this site is 1.09 square miles, which provides an adequate amount of water for sampling during storm events. This site has no traffic problems and is readily accessible from Benson Road. Because of the uniform channel, the site is a good location for collecting flow and water-quality data. A concrete weir was constructed across the open channel (which is about 20 feet wide from top-of-bank to top-of-bank) to provide hydraulic control and to pond the water slightly for sampling during storm events.

Site 3, representative of residential land use, is located in the southwest part of Sioux Falls between 26th and 33rd Streets and drains the Kingswood Estates. The sampling site is in a concrete-lined open channel upstream of three 54-inch culverts. This channel drains into Skunk Creek (a tributary of the Big Sioux River) about one-third of a mile north of the sampling site. About 76 percent of the drainage basin upstream of this water-quality sampling site is developed as residential land use. The remainder of the upstream drainage basin is classified as parks and recreation (17.4 percent) or commercial ( 6.5 percent). The drainage area upstream of this site is 0.51 square mile. This site has little traffic and is readily accessible from 26 th Street. Because of the uniform channel and concrete lining, the site is an ideal location for collecting flow and water-quality data. A weir was installed across the channel to provide hydraulic control and to pond the water slightly for sampling during storm events. 

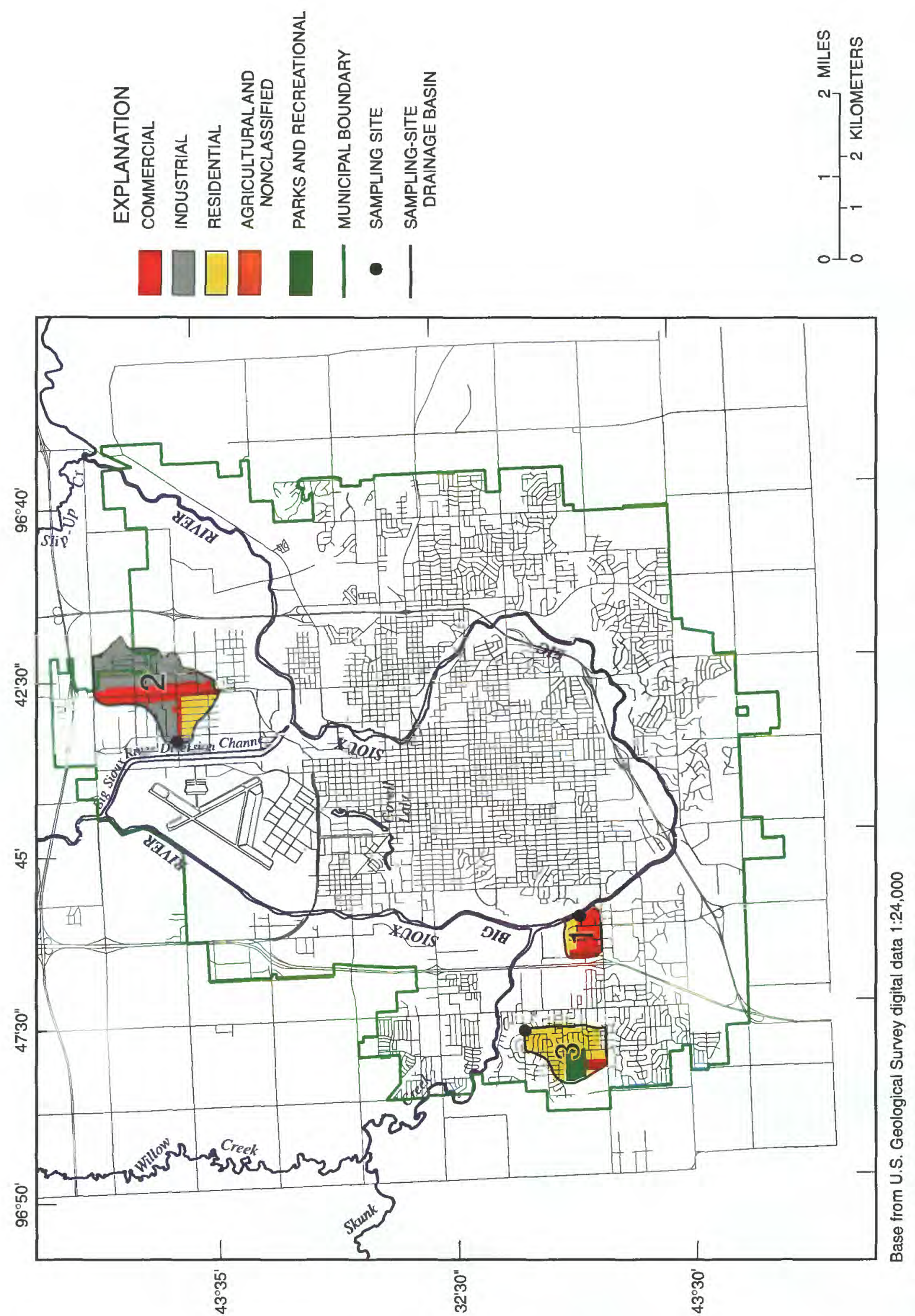

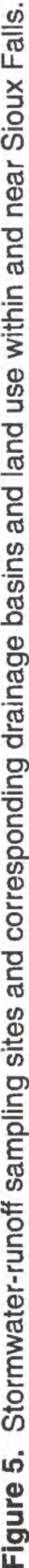




\section{Site Instrumentation}

Instrument shelters were installed on the banks of the open channels at each of the three sampling sites. Instrumentation at each site included a pressure transducer to measure stream stage and a tipping-bucket rain gage installed on the roof of the shelters to measure precipitation volume and intensity. Data from these instruments were recorded by a data logger that also served to activate an automatic water-quality sampler to initiate stream-sample collection when stream stages reached pre-selected levels. Each site also had phone service and associated modems that allowed communication with the data logger such that stream-stage and precipitation data could be monitored from remote locations. Also, appropriate adjustments could be made by phone to the programs that controlled the activation of the automatic sampler.

Concrete control structures were constructed in the open channels at the commercial and industrial sites, and a metal control structure was fastened to the concrete lining of the open channel at the residential site. Stage-discharge ratings initially were established by indirect methods and later verified by manual current-meter discharge measurements.

The automatic samplers were installed according to the following guidelines:

1. the intake hose was located above the channel bottom in an area of well-mixed flow;

2. the intake hose and sample container materials were selected so as to prevent metal or organic contamination of samples;

3. the sampler was located at a minimum height above the intake hose so that the automatic sampler could pump water during sampling.

\section{Sample Collection and Processing}

A detailed protocol was developed to satisfy USEPA requirements for water-quality sampling for NPDES purposes and was revised by the SDDENR, which was designated by the USEPA as South Dakota's NPDES certifying agent. This protocol is presented in the Supplemental Information section (at the end of the report) and was used for all phases of the water-quality sampling program. This protocol included instructions for standard observations upon arrival at the monitoring sites, for grab sampling, for operation of the automatic samplers and stage-collection equipment, for preparation of the flow-weighted composite samples from discretely collected samples, for field quality assurance, for preservation of the samples for laboratory analyses, for shipping, and for tracking.

All equipment used for sample collection and processing was cleaned by personnel wearing latex gloves by washing with nonphosphate detergent and tap water, rinsing with tap water, rinsing with deionized water, rinsing with methanol, and rinsing again with deionized water. All equipment then was allowed to air dry. All openings then were covered with aluminum foil.

Collection, processing, and analysis information for the various samples are summarized in table 6. Constituents including bacteria, cyanide, oil and grease, volatile organic compounds (VOC's), and total phenols were collected as grab samples. The grab samples typically were collected manually (not using the automatic samplers) just below the water surface in the middle of open channels within 1 hour after runoff commenced from acceptable storms. Samples collected in the channels were considered to be representative because the flow was well mixed during stormwater runoff. Field measurements of specific conductance, $\mathrm{pH}$, water temperature, and total residual chlorine were made at approximately the same time that the grab samples were collected. Total residual chlorine was determined by using a field test that estimates free and total chlorine. If residual chlorine had been detected in any of the samples, it would have been necessary to add sodium thiosulfate or ascorbic acid when analyzing for bacteria, cyanide, or VOC's.

Discrete samples intended for later flowweighted compositing typically were collected using automatic samplers during the first hour of the storm. The automatic samplers were programmed to collect $3,750 \mathrm{~mL}$ (milliliter) every 15 minutes once the samplers were triggered by specific stages. A total of four 3,750-mL glass jars were filled by each sampler. Additional discrete samples were collected manually every 15 minutes for the remainder of the stormwater-runoff period or for a maximum of two additional hours by wading near the middle of the channel and filling 1-gallon glass jars just below the water surface. Total sampling time was a maximum of 3 hours from the start of runoff or until the storm ended and the stage in the channel returned to its pre-storm level. Additional 1-gallon glass jars, if available, were filled near the runoff peak to ensure that enough water was available for the flow-weighted compositing that was performed later. 
Table 6. Collection, processing, and analysis information associated with sampling of stormwater runoff in Sioux Falls [USGS (field), determined at the sampling site by U.S. Geological Survey personnel; USGS, performed at Sioux Falls Water Purification Plant by U.S. Geological Survey personnel; Quanterra, Quanterra Environmental Services in Arvada, Colo.; poly, polyethylene; BOD, biochemical oxygen demand; grab, grab sample during initial 2 hours of storm; composite, flow-weighted composite sample; $\mathrm{L}$, liter; $\mathrm{mL}$, milliliters; $\mu \mathrm{L}$, microliters; HCL, hydrochloric acid; $\mathrm{HNO}_{3}$, nitric acid; $\mathrm{H}_{2} \mathrm{SO}_{4}$, sulfuric acid; $\mathrm{NaOH}$, sodium hydroxide; --, not applicable]

\begin{tabular}{|c|c|c|c|c|c|c|}
\hline Constituent or property & $\begin{array}{l}\text { Collection } \\
\text { method }\end{array}$ & $\begin{array}{l}\text { Analyzing } \\
\text { laboratory }\end{array}$ & Filtration & $\begin{array}{l}\text { Sample } \\
\text { container }\end{array}$ & $\begin{array}{l}\text { Preservative } \\
\text { (amount/ } \\
\text { strength) }\end{array}$ & $\begin{array}{l}\text { Maximum } \\
\text { holding time }\end{array}$ \\
\hline Cyanide & Grab & Quanterra & No & 250-mL poly & $\begin{array}{l}\mathrm{NaOH} \\
(2 \mathrm{~mL} / 50 \%)\end{array}$ & 14 days \\
\hline Oil and grease & Grab & Quanterra & No & 1-L glass & $\begin{array}{l}\mathrm{H}_{2} \mathrm{SO}_{4} \\
(4 \mathrm{~mL} / 50 \%)\end{array}$ & 28 days \\
\hline $\begin{array}{l}\mathrm{pH} \text {, specific conductance, } \\
\text { and alkalinity }\end{array}$ & Composite & Quanterra & No & Included with BOD & -- & 14 days \\
\hline $\begin{array}{l}\text { Chemical oxygen demand, } \\
\text { organic carbon, and } \\
\text { nutrients (except dissolved } \\
\text { phosphorus) }\end{array}$ & Composite & Quanterra & No & 500-mL glass & $\begin{array}{l}\mathrm{H}_{2} \mathrm{SO}_{4} \\
(2 \mathrm{~mL} / 50 \%)\end{array}$ & 28 days \\
\hline BOD & Composite & Quanterra & No & 1-L poly & -- & 48 hours \\
\hline $\begin{array}{l}\text { Dissolved calcium, } \\
\text { magnesium, potassium, } \\
\text { and sodium }\end{array}$ & Composite & Quanterra & Yes & 500-mL poly & $\begin{array}{l}\mathrm{HNO}_{3} \\
(10 \mathrm{~mL} / 20 \%)\end{array}$ & 28 days \\
\hline Dissolved phosphorus & Composite & Quanterra & Yes & 500-mL glass & $\begin{array}{l}\mathrm{H}_{2} \mathrm{SO}_{4} \\
(2 \mathrm{~mL} / 50 \%)\end{array}$ & 28 days \\
\hline Metals & Composite & Quanterra & No & 500-mL poly & $\begin{array}{l}\mathrm{HNO}_{3} \\
(10 \mathrm{~mL} / 20 \%)\end{array}$ & 6 months \\
\hline Mercury & Composite & Quanterra & No & Included with metals & $\mathrm{HNO}_{3}$ & 13 days \\
\hline Petroleum hydrocarbons & Composite & Quanterra & No & $1-\mathrm{L}$ glass & $\begin{array}{l}\mathrm{H}_{2} \mathrm{SO}_{4} \\
(4 \mathrm{~mL} / 50 \%)\end{array}$ & 28 days \\
\hline $\begin{array}{l}\text { Acid and base/neutral } \\
\text { organic compounds }\end{array}$ & Composite & Quanterra & No & Two 1-L glass (amber) & -- & $\begin{array}{l}7 \text { days until } \\
\text { extraction; } \\
40 \text { days after } \\
\text { extraction }\end{array}$ \\
\hline Pesticide organic compounds & Composite & Quanterra & No & Two 1-L glass & -- & $\begin{array}{l}7 \text { days until } \\
\text { extraction; } \\
40 \text { days after } \\
\text { extraction }\end{array}$ \\
\hline
\end{tabular}


Field sample containers were made of glass with Teflon-lined lids. All samples collected either by manual sampling or by the automatic samplers were chilled by storing in ice chests as soon as possible after collection. Samples were taken to the Sioux Falls Water Purification Plant immediately after sampling was completed to facilitate processing and shipping to the analytical laboratory within the allowable holding times.

The discrete samples were composited at the Sioux Falls Water Purification Plant in direct proportion to the discharge occurring at the respective times of collection. The discharge at the sampling time for each discrete sample was determined from the stage/ discharge rating curve for the site. The volumetric proportion of the total sample volume represented by a given discrete sample was calculated by the ratio of discharge at the time of the given discrete sample to the sum of discharges for all the discrete samples collected during the storm event. Because the time interval between collection of discrete samples was consistent (15 minutes), this discharge ratio represents the volumetric proportion of a given discrete sample relative to the stream volume passing the sampling site for the total sampling period. The discharge ratios were used to determine the appropriate volume of each discrete sample that would yield a final flow-weighted composite sample volume of about 11 to $12 \mathrm{~L}$ (liters) that would be representative of the entire storm sampling period. The calculated volume for each discrete sample was measured by pumping water into a glass graduated cylinder while the sample in the sample bottle was being continuously stirred with a Teflon stir rod. The appropriate measured volumes were then subdivided into 10 one-gallon glass bottles using a cone splitter constructed such that all parts in contact with the sample water were made of Teflon. This compositing procedure ensured that the samples contained in each of the 10 one-gallon glass bottles receiving sample water from the cone splitter were flowweighted composites representing the entire sampling period for the storm event. Sample water from the 10 one-gallon glass bottles was then decanted into individual sample containers provided by Quanterra
Environmental Services in Arvada, Colo., that already contained appropriate preservatives as outlined in 40CFR Part 136 (U.S. Environmental Protection Agency, 1990). Samples requiring filtering were pumped from the 10 one-gallon glass bottles through a capsule-filter unit into individual sample bottles with appropriate preservatives. After the individual sample bottles were filled, they were packed in shipping containers (filled with ice where appropriate) and sent to Quanterra Environmental Services for analysis.

The samples were handled under chain-ofcustody procedures. A chain-of-custody record was attached to each ice chest containing the grab and discrete samples before the chests were shipped to Quanterra Environmental Services. The original record was sealed in a plastic, ziplock-type bag and put in the sample shipping ice chests prior to shipping; a copy was retained by field personnel. A laboratory request form accompanied the chain-of-custody record, which identified the constituents or properties to be analyzed, sample containers designated for each parameter, and preservation methods used. Grab samples collected for bacteria analyses were processed at the Sioux Falls Water Purification Plant by USGS personnel.

\section{Sample Analysis}

The samples collected for this study generally were analyzed by Quanterra Environmental Services in Arvada, Colo. Exceptions were analyses for bacteria and miscellaneous field measurements, which were performed by USGS personnel. The methods used to analyze selected constituents or properties for the stormwater runoff are shown in table 7 . The analytical methods used are USEPA-approved methods except for the bacterial analyses. Procedures for bacteria analyses were patterned after Fishman and Friedman (1989) and were approved by SDDENR. Specific procedures used in bacteria analyses are included in the Supplemental Information section. 
Table 7. Laboratory methods of analysis for selected constituents or properties for stormwater runoff in Sioux Falls

[USEPA, U.S. Environmental Protection Agency. Analyses done by Quanterra Environmental Services in Arvada, Colo., unless otherwise noted by “*," then analyses done by U.S. Geological Survey in Huron, S. Dak. Biochemical oxygen demand analyses done by both Quanterra and U.S. Geological Survey (Huron). Analytical methods as specified in NPDES stormwater sampling guidance document (U.S. Environmental Protection Agency, 1992a)]

\begin{tabular}{|c|c|c|c|}
\hline Constituent or property & Analytical method & Constituent or property & Analytical \\
\hline Properties & & Volatile organic compounds-Continued & \\
\hline (1) Specific conductance & USEPA 120.1 & (5) Carbon tetrachloride & USEPA 624 \\
\hline (2) $\mathrm{pH}$ & USEPA 150.1 & (6) Chlorobenzene & USEPA 624 \\
\hline (3) Chemical oxygen demand & USEPA 410.4 & (7) Chlorodibromomethane & USEPA 624 \\
\hline (4) Biochemical oxygen demand & USEPA 405.1 & (8) Chloroethane & USEPA 624 \\
\hline (5) Alkalinity, total & USEPA 310.2 & (9) 2-chloroethylvinyl ether & USEPA 624 \\
\hline Bacteria & & (10) Chloroform & USEPA 624 \\
\hline (1) Total coliform* & USGS B-0025-85 & (11) Dichlorobromomethane & USEPA 624 \\
\hline (2) Fecal coliform* & USGS B-0050-85 & (12) 1,1-dichloroethane & USEPA 624 \\
\hline (3) Fecal streptococcus* & USGS B-0055-85 & (13) 1,2-dichloroethane & USEPA 624 \\
\hline Major ions & & (14) 1,1-dichloroethylene & USEPA 624 \\
\hline (1) Calcium, dissolved & USEPA 200.7 & (15) 1,2-dichloropropane & USEPA 624 \\
\hline (2) Magnesium, dissolved & USEPA 200.7 & (16) 1,3-dichloropropylene & USEPA 624 \\
\hline (3) Sodium, dissolved & USEPA 200.7 & (17) Ethylbenzene & USEPA 624 \\
\hline (4) Potassium, dissolved & USEPA 200.7 & (18) Methyl bromide & USEPA 624 \\
\hline (5) Sulfate, dissolved & USEPA 300.0 & (19) Methyl chloride & USEPA 624 \\
\hline (6) Chlorine, residual & USEPA 330.1 & (20) Methylene chloride & USEPA 624 \\
\hline (7) Chloride, dissolved & USEPA 300.0 & (21) 1,1,2,2-tetrachloroethane & USEPA 624 \\
\hline Dissolved or suspended solids & & (22) Tetrachloroethylene & USEPA 624 \\
\hline (1) Solids, dissolved & USEPA 160.1 & (23) Toluene & USEPA 624 \\
\hline (2) Solids, suspended & USEPA 160.2 & (24) 1,2-trans-dichloroethylene & USEPA 624 \\
\hline Nutrients & & (25) 1,1,1-trichloroethane & USEPA 624 \\
\hline (1) Nitrogen, nitrite plus nitrate & USEPA 353.2 & (26) 1,1,2-trichloroethane & USEPA 624 \\
\hline (2) Nitrogen, total Kjeldahl & USEPA 351.2 & (27) Trichloroethylene & USEPA 624 \\
\hline (3) Nitrogen, total & $\begin{array}{l}\text { USEPA } 351.2 \& \\
\text { USEPA } 353.2\end{array}$ & $\begin{array}{l}\text { (28) Vinyl chloride } \\
\text { Base/neutral organic compounds }\end{array}$ & USEPA 624 \\
\hline (4) Phosphorous, total & USEPA 365.3 & (1) Acenaphthene & USEPA 625 \\
\hline (5) Phosphorous, dissolved & USEPA 365.3 & (2) Acenapthylene & USEPA 625 \\
\hline Metals or trace elements & & (3) Anthracene & USEPA 625 \\
\hline (1) Antimony, total & USEPA 200.7 & (4) Benzidine & USEPA 625 \\
\hline (2) Arsenic, total & USEPA 206.2 & (5) Benzo a anthracene & USEPA 625 \\
\hline (3) Beryllium, total & USEPA 200.7 & (6) Benzo a pyrene & USEPA 625 \\
\hline (4) Cadmium, total & USEPA 200.7 & (7) 3,4-benzofluoroanthene & USEPA 625 \\
\hline (5) Chromium, total & USEPA 200.7 & (8) Benzo(ghi)perylene & USEPA 625 \\
\hline (6) Copper, total & USEPA 200.7 & (9) Benzo(K)fluoranthene & USEPA 625 \\
\hline (7) Lead, total & USEPA 200.7 & (10) Bis (2-chloroethoxy) methane & USEPA 625 \\
\hline (8) Mercury, total & USEPA 245.1 & (11) Bis (2-chloroethyl) ether & USEPA 625 \\
\hline (9) Nickel, total & USEPA 200.7 & (12) Bis (2-chloroisopropyl) ether & USEPA 625 \\
\hline (10) Selenium, total & USEPA 200.7 & (13) Bis (2-ehylhexyl) phthalate & USEPA 625 \\
\hline (11) Silver, total & USEPA 272.2 & (14) 4-bromophenyl phenyl ether & USEPA 625 \\
\hline (12) Thallium, total & USEPA 279.2 & (15) Butylbenzyl phthalate & USEPA 625 \\
\hline (13) Zinc, total & USEPA 200.7 & (16) 2-chloronaphthalene & USEPA 625 \\
\hline (14) Cyanide, total & USEPA 335.3 & (17) 4-chlorophenyl phenyl ether & USEPA 625 \\
\hline Organic compounds & & (18) Chrysene & USEPA 625 \\
\hline (1) Total organic carbon & USEPA 415.1 & (19) Dibenzo(A,h)anthracene & USEPA 625 \\
\hline (2) Oil and grease & USEPA 413.1 & (20) 1,2-dichlorobenzene & USEPA 625 \\
\hline (3) Petroleum hydrocarbons, total & USEPA 418.1 & (21) 1,3-dichlorobenzene & USEPA 625 \\
\hline Volatile organic compounds & & (22) 1,4-dichlorobenzene & USEPA 625 \\
\hline (1) Acrolein & USEPA 624 & (23) 3,3'-dichlorobenzidine & USEPA 625 \\
\hline (2) Acrylonitrile & USEPA 624 & (24) Diethyl phthalate & USEPA 625 \\
\hline (3) Benzene & USEPA 624 & (25) Dimethyl phthalate & USEPA 625 \\
\hline (4) Bromoform & USEPA 624 & (26) Di-n-butyl phthalate & USEPA 625 \\
\hline
\end{tabular}


Table 7. Laboratory methods of analysis for selected constituents or properties for stormwater runoff in Sioux Falls-Continued

\begin{tabular}{|c|c|c|c|}
\hline Constituent or property & Analytical method & Constituent or property & Analytical method \\
\hline \multicolumn{2}{|c|}{ Base/neutral organic compounds - Continued } & Acid organic compounds - Continued & \\
\hline (27) 2,4-dinitrotoluene & USEPA 625 & (10) Phenols, total & USEPA 420.1 \\
\hline (28) 2,6-dinitrotoluene & USEPA 625 & (11) Phenol & USEPA 625 \\
\hline (29) Di-n-octyl phthalate & USEPA 625 & (12) 2,4,6-trichlorophenol & USEPA 625 \\
\hline $\begin{array}{l}\text { (30) 1,2-diphenylhydrazine (as } \\
\text { azobenzene) }\end{array}$ & USEPA 625 & $\begin{array}{l}\text { Pesticide organic compounds } \\
\text { (1) Aldrin }\end{array}$ & USEPA 608 \\
\hline (31) Fluoranthene & USEPA 625 & (2) Alpha-BHC & USEPA 608 \\
\hline (32) Fluorene & USEPA 625 & (3) Beta-BHC & USEPA 608 \\
\hline (33) Hexachlorobenzene & USEPA 625 & (4) Gamma-BHC & USEPA 608 \\
\hline (34) Hexachlorobutadiene & USEPA 625 & (5) Delta-BHC & USEPA 608 \\
\hline (35) Hexachlorocyclopentadiene & USEPA 625 & (6) Chlordane & USEPA 608 \\
\hline (36) Hexachloroethane & USEPA 625 & (7) $4,4^{\prime}-\mathrm{DDT}$ & USEPA 608 \\
\hline (37) Indeno $(1,2,3-c d)$ pyrene & USEPA 625 & (8) 4,4 '-DDE & USEPA 608 \\
\hline (38) Isophorone & USEPA 625 & (9) 4,4'-DDD & USEPA 608 \\
\hline (39) Napthalene & USEPA 625 & (10) Diazinon & USEPA 608 \\
\hline (40) Nitrobenzene & USEPA 625 & (11) Dieldrin & USEPA 608 \\
\hline (41) N-nitrosodimethylamine & USEPA 625 & (12) Alpha-endosulfan & USEPA 608 \\
\hline (42) N-nitrosodi-n-propylamine & USEPA 625 & (13) Beta-endosulfan & USEPA 608 \\
\hline (43) N-nitrosodiphenylamine & USEPA 625 & (14) Endosulfan sulfate & USEPA 608 \\
\hline (44) Phenanthrene & USEPA 625 & (15) Endrin & USEPA 608 \\
\hline (45) Pyrene & USEPA 625 & (16) Endrin aldehyde & USEPA 608 \\
\hline (46) 1,2,4-trichlorobenzene & USEPA 625 & (17) Heptachlor & USEPA 608 \\
\hline Acid organic compounds & & (18) Heptachlor epoxide & USEPA 608 \\
\hline (1) 2-chlorophenol & USEPA 625 & (19) PCB-1242 & USEPA 608 \\
\hline (2) 2,4-dichlorophenol & USEPA 625 & (20) PCB-1254 & USEPA 608 \\
\hline (3) 2,4-dimethylphenol & USEPA 625 & (21) PCB-1221 & USEPA 608 \\
\hline (4) 4,6-dinitro-o-cresol & USEPA 625 & (22) PCB-1232 & USEPA 608 \\
\hline (5) 2,4-dinitrophenol & USEPA 625 & (23) PCB-1248 & USEPA 608 \\
\hline (6) 2-nitrophenol & USEPA 625 & (24) PCB-1260 & USEPA 608 \\
\hline (7) 4-nitrophenol & USEPA 625 & (25) PCB-1016 & USEPA 608 \\
\hline (8) P-chloro-m-cresol & USEPA 625 & (26) Toxaphene & USEPA 608 \\
\hline (9) Pentachlorophenol & USEPA 625 & & \\
\hline
\end{tabular}

\section{Quality Assurance}

Quality assurance (QA) procedures were used to produce data of known quality. QA steps were used both in collection and in analyses of the samples.

Instruments used in the field to measure properties such as $\mathrm{pH}$ and specific conductance were calibrated with reference standards daily prior to field use. Calibration records were maintained, including instrument type, date, and response.

QA samples submitted from the field for laboratory analysis consisted of two field-equipment blanks and one field replicate. Field-equipment blanks were used to assess sample contamination that could have occurred during collection, handling, compositing, shipment, storage, and analysis of the samples. Before each automatic sampler was placed in service, the units were cleaned by pumping nonphosphate detergent and water through the pump and tubing, followed by rinses with tap water, methanol, and deionized water. Before the actual sampling was begun, an equipment blank was collected (Mar. 23, 1995) at the industrial site (the site considered to have the greatest potential for contamination) by pumping inorganic- and organic-free blank water provided by Quanterra Environmental Services through the unit, and processing and analyzing the sample using identical procedures as for the flowweighted samples. After the sampling program was completed, another equipment blank was collected (July 9, 1996) at this site and subsequently analyzed. QA results of field-equipment blanks collected at the industrial sampling site are shown in table 8 . No constituents were detected in the field-equipment blanks with the exception of small concentrations of dissolved calcium, dissolved solids, nitrite plus nitrate, total zinc, and total organic carbon. Some possible sample contamination is indicated from the automatic sampler, compositing procedure, laboratory analysis, or the blank water itself. 
Table 8. Quality-assurance results of field-equipment blanks for flow-weighted constituents or properties collected at the industrial site

[Analyses by Quanterra Environmental Services laboratory in Arvada, Colo. Values in micrograms per liter except where indicated. mg/L, milligrams per liter; $\mu \mathrm{S} / \mathrm{cm}$, microsiemens per centimeter at $25^{\circ} \mathrm{C}$; $<$, less than indicated reporting limit]

\begin{tabular}{|c|c|c|c|c|c|}
\hline Constituent or property & $03 / 23 / 95$ & $07 / 09 / 96$ & Constituent or property & $03 / 23 / 95$ & $07 / 09 / 96$ \\
\hline Properties & & & Organic compounds & & \\
\hline \multirow{2}{*}{$\begin{array}{l}\text { Specific conductance (lab) } \\
(\mu \mathrm{S} / \mathrm{cm})\end{array}$} & 3.8 & 4.0 & \multirow{3}{*}{$\begin{array}{l}\text { Total organic carbon }(\mathrm{mg} / \mathrm{L}) \\
\text { Petroleum hydrocarbons, total } \\
(\mathrm{mg} / \mathrm{L})\end{array}$} & 1.2 & $<1.0$ \\
\hline & & & & \multirow[t]{2}{*}{$<1.0$} & \multirow[t]{2}{*}{$<1.0$} \\
\hline $\mathrm{pH}$ (lab) & 6.3 & 6.6 & & & \\
\hline \multirow{2}{*}{$\begin{array}{l}\text { Chemical oxygen demand } \\
(\mathrm{mg} / \mathrm{L})\end{array}$} & $<20.0$ & $<20.0$ & \multicolumn{2}{|l|}{ Base/neutral organic compounds } & \\
\hline & & & Acenaphthene & $<10$ & $<9.8$ \\
\hline \multirow{2}{*}{$\begin{array}{l}\text { Biochemical oxygen demand } \\
(\mathrm{mg} / \mathrm{L})\end{array}$} & \multirow[t]{2}{*}{$<2.0$} & \multirow[t]{2}{*}{11.8} & Acenapthylene & $<10$ & $<9.8$ \\
\hline & & & Anthracene & $<10$ & $<9.8$ \\
\hline \multirow{2}{*}{$\begin{array}{l}\text { Alkalinity, total }(\mathrm{mg} / \mathrm{L} \text { as } \\
\left.\mathrm{CaCO}_{3}\right)\end{array}$} & \multirow[t]{2}{*}{$<5.0$} & \multirow[t]{2}{*}{$<5.0$} & Benzidine & $<100$ & $<98$ \\
\hline & & & Benzo a anthracene & $<10$ & $<9.8$ \\
\hline \multicolumn{3}{|l|}{ Major ions } & Benzo a pyrene & $<10$ & $<9.8$ \\
\hline Calcium, dissolved (mg/L) & $<0.20$ & 0.33 & 3,4-benzofluoroanthene & $<10$ & $<9.8$ \\
\hline Magnesium, dissolved (mg/L) & $<0.20$ & $<0.20$ & Benzo(ghi)perylene & $<10$ & $<9.8$ \\
\hline Sodium, dissolved (mg/L) & $<5.0$ & $<5.0$ & Benzo(K)fluoranthene & $<10$ & $<9.8$ \\
\hline Potassium, dissolved (mg/L) & $<5.0$ & $<5.0$ & Bis (2-chloroethoxy) methane & $<10$ & $<9.8$ \\
\hline Sulfate, dissolved (mg/L) & $<0.50$ & $<0.50$ & Bis (2-chloroethyl) ether & $<10$ & $<9.8$ \\
\hline Chloride, dissolved (mg/L) & $<0.50$ & $<0.50$ & Bis (2-chloroisopropyl) ether & $<10$ & $<9.8$ \\
\hline \multicolumn{3}{|l|}{ Dissolved or suspended solids } & Bis (2-ehylhexyl) phthalate & $<10$ & $<9.8$ \\
\hline Solids, total dissolved $(\mathrm{mg} / \mathrm{L})$ & $<10.0$ & 12.0 & 4-bromophenyl phenyl ether & $<10$ & $<9.8$ \\
\hline Solids, total suspended (mg/L) & $<2.0$ & $<2.0$ & Butylbenzyl phthalate & $<10$ & $<9.8$ \\
\hline \multicolumn{3}{|l|}{ Nutrients } & 2-chloronaphthalene & $<10$ & $<9.8$ \\
\hline \multirow{2}{*}{$\begin{array}{l}\text { Nitrogen, nitrite plus nitrate } \\
(\mathrm{mg} / \mathrm{L})\end{array}$} & \multirow[t]{2}{*}{$<0.10$} & \multirow[t]{2}{*}{0.39} & 4-chlorophenyl phenyl ether & $<10$ & $<9.8$ \\
\hline & & & Chrysene & $<10$ & $<9.8$ \\
\hline \multirow{2}{*}{$\begin{array}{l}\text { Nitrogen, total Kjeldahl } \\
(\mathrm{mg} / \mathrm{L})\end{array}$} & \multirow[t]{2}{*}{$<0.50$} & \multirow[t]{2}{*}{$<0.50$} & Dibenzo(A,h)anthracene & $<10$ & $<9.8$ \\
\hline & & & 1,2-dichlorobenzene & $<10$ & $<9.8$ \\
\hline Nitrogen, total $(\mathrm{mg} / \mathrm{L})$ & $<0.60$ & $<0.89$ & 1,3-dichlorobenzene & $<10$ & $<9.8$ \\
\hline Phosphorous, total (mg/L) & $<0.050$ & $<0.050$ & 1,4-dichlorobenzene & $<10$ & $<9.8$ \\
\hline \multirow{2}{*}{$\begin{array}{l}\text { Phosphorous, dissolved } \\
(\mathrm{mg} / \mathrm{L})\end{array}$} & \multirow[t]{2}{*}{$<0.050$} & \multirow[t]{2}{*}{$<0.050$} & 3,3'-dichlorobenzidine & $<20$ & $<20.0$ \\
\hline & & & Diethyl phthalate & $<10$ & $<9.8$ \\
\hline Metals or trace elements & & & Dimethyl phthalate & $<10$ & $<9.8$ \\
\hline Antimony, total (mg/L) & $<0.060$ & $<0.060$ & Di-n-butyl phthalate & $<10$ & $<9.8$ \\
\hline Arsenic, total (mg/L) & $<0.0050$ & $<0.0050$ & 2,4-dinitrotoluene & $<10$ & $<9.8$ \\
\hline Beryllium, total $(\mathrm{mg} / \mathrm{L})$ & $<0.0020$ & $<0.0020$ & 2,6-dinitrotoluene & $<10$ & $<9.8$ \\
\hline Cadmium, total (mg/L) & $<0.0050$ & $<0.0050$ & Di-n-octyl phthalate & $<10$ & $<9.8$ \\
\hline Chromium, total $(\mathrm{mg} / \mathrm{L})$ & $<0.010$ & $<0.010$ & 1,2-diphenylhydrazine (as & $<10$ & $<9.8$ \\
\hline Copper, total (mg/L) & $<0.020$ & $<0.020$ & & & \\
\hline Lead, total (mg/L) & $<0.050$ & $<0.050$ & Fluoranthene & $<10$ & $<9.8$ \\
\hline Mercury, total (mg/L) & $<0.00020$ & $<0.00020$ & Fluorene & $<10$ & $<9.8$ \\
\hline Nickel, total (mg/L) & $<0.040$ & $<0.040$ & Hexachlorobenzene & $<10$ & $<9.8$ \\
\hline Selenium, total $(\mathrm{mg} / \mathrm{L})$ & $<0.20$ & $<0.20$ & Hexachlorobutadiene & $<10$ & $<9.8$ \\
\hline Silver, total $(\mathrm{mg} / \mathrm{L})$ & $<0.00050$ & $<0.00050$ & Hexachlorocyclopentadiene & $<10$ & $<9.8$ \\
\hline Thallium, total (mg/L) & $<0.0050$ & $<0.0050$ & Hexachloroethane & $<10$ & $<9.8$ \\
\hline Zinc, total $(\mathrm{mg} / \mathrm{L})$ & 0.023 & $<0.020$ & Indeno (1,2,3-cd) pyrene & $<10$ & $<9.8$ \\
\hline
\end{tabular}


Table 8. Quality-assurance results of field-equipment blanks for flow-weighted constituents or properties collected at the industrial site-Continued

\begin{tabular}{|c|c|c|c|c|c|}
\hline Constituent or property & 03/23/95 & 07/09/96 & Constituent or property & $03 / 23 / 95$ & 07/09/96 \\
\hline \multicolumn{3}{|c|}{ Base/neutral organic compounds-Continued } & \multicolumn{3}{|c|}{ Pesticide organic compounds-Continued } \\
\hline Isophorone & $<10$ & $<9.8$ & Beta-BHC & $<0.050$ & $<0.049$ \\
\hline Napthalene & $<10$ & $<9.8$ & Gamma-BHC & $<0.050$ & $<0.049$ \\
\hline Nitrobenzene & $<10$ & $<9.8$ & Delta-BHC & $<0.050$ & $<0.049$ \\
\hline $\mathrm{N}$-nitrosodimethylamine & $<10$ & $<9.8$ & Chlordane & $<0.50$ & $<0.50$ \\
\hline N-nitrosodi-n-propylamine & $<10$ & $<9.8$ & 4,4'-DDT & $<0.10$ & $<0.097$ \\
\hline $\mathrm{N}$-nitrosdiphenylamine & $<10$ & $<9.8$ & 4,4'-DDE & $<0.10$ & $<0.097$ \\
\hline Phenanthrene & $<10$ & $<9.8$ & $4,4^{\prime}-\mathrm{DDD}$ & $<0.10$ & $<0.097$ \\
\hline Pyrene & $<10$ & $<9.8$ & Diazinon & $<0.25$ & $<0.24$ \\
\hline 1,2,4-trichlorobenzene & $<10$ & $<9.8$ & Dieldrin & $<0.10$ & $<0.097$ \\
\hline Acid organic compounds & & & Alpha-endosulfan & $<0.050$ & $<0.049$ \\
\hline 2-chlorophenol & $<10$ & $<9.8$ & Beta-endosulfan & $<0.10$ & $<0.097$ \\
\hline 2,4-dichlorophenol & $<10$ & $<9.8$ & Endosulfan sulfate & $<0.10$ & $<0.097$ \\
\hline 2,4-dimethylphenol & $<10$ & $<9.8$ & Endrin & $<0.10$ & $<0.097$ \\
\hline 4,6-dinitro-o-cresol & $<50$ & $<49$ & Endrin aldehyde & $<0.10$ & $<0.097$ \\
\hline 2,4-dinitrophenol & $<50$ & $<49$ & Heptachlor & $<0.050$ & $<0.049$ \\
\hline 2-nitrophenol & $<10$ & $<9.8$ & Heptachlor epoxide & $<0.050$ & $<0.049$ \\
\hline 4-nitrophenol & $<50$ & $<49$ & PCB-1242 & $<1.0$ & $<0.97$ \\
\hline P-chloro-m-cresol & $<10$ & $<9.8$ & PCB-1254 & $<1.0$ & $<0.97$ \\
\hline Pentachlorophenol & $<50$ & $<49$ & PCB-1221 & $<2.0$ & $<1.9$ \\
\hline Phenol & $<10$ & $<9.8$ & PCB-1232 & $<1.0$ & $<0.97$ \\
\hline 2,4,6-trichlorophenol & $<10$ & $<9.8$ & PCB-1248 & $<1.0$ & $<0.97$ \\
\hline Pesticide organic compounds & & & PCB-1260 & $<1.0$ & $<0.97$ \\
\hline Aldrin & $<0.050$ & $<0.049$ & PCB-1016 & $<1.0$ & $<0.97$ \\
\hline Alpha-BHC & $<0.050$ & $<0.049$ & Toxaphene & $<5.0$ & $<4.9$ \\
\hline
\end{tabular}

Field replicates were used to assess the variability in the results due to variability in field collection, handling, shipment, and storage procedures and in laboratory handling, storage, and analysis procedures. The field replicates were grab samples collected at the commercial site at the same location and immediately following collection of the primary grab samples.

Field replicates were collected only for constituents or properties to be submitted for laboratory analysis.

Field replicates were not performed for flow-weighted composite samples. The water-quality results from the commercial site field replicates were identical to the results from the primary commercial site samples.

Quality-assurance results of field replicates are shown in table 9.

Laboratory QA samples prepared and analyzed by Quanterra Environmental Services consisted of method blanks, duplicate control samples, matrix spikes, and duplicate matrix spikes. Method blanks were used to assess the potential sample contamination attributable to laboratory-analysis procedures. Method blanks were analyzed at a minimum frequency of one per 20 samples. The duplicate control samples consisted of reagent water spiked with some of the analytes of concern. The purpose of the duplicate control samples is not to duplicate the sample matrix, but rather to provide an interference-free homogeneous matrix from which to gather data to establish control limits. These limits are used to monitor the data generated by the laboratory. The matrix spikes involved introducing surrogates, which are non-target compounds, into every sample to provide an additional indication of accuracy. Matrix-spiked samples were used to estimate matrix recovery of organic compounds and laboratory accuracy. A duplicate matrix-spiked sample was analyzed each time that a matrix-spiked sample was analyzed to provide an estimate of laboratory precision. The samples were spiked prior to any extractions performed 
during the analysis. The matrix-spiked and duplicate matrix-spiked samples were analyzed at a frequency of one per 20 samples.

Table 9. Quality-assurance results of field replicates for grab constituents or properties collected at the commercial site

[Analyses by Quanterra Environmental Services laboratory in Arvada, Colo. Values in micrograms per liter except where indicated. $\mathrm{mg} / \mathrm{L}$, milligrams per liter; ND, not detected; <, less than indicated reporting limit]

\begin{tabular}{|c|c|c|c|}
\hline Constituent or property & $\begin{array}{c}\text { Com- } \\
\text { mercial } \\
(07-03-96)\end{array}$ & $\begin{array}{c}\text { Com- } \\
\text { mercial } \\
\text { replicate } \\
(07-03-96)\end{array}$ & Precision \\
\hline \multicolumn{4}{|l|}{ Metal or trace element } \\
\hline Cyanide, total $(\mathrm{mg} / \mathrm{L})$ & $<0.010$ & $<0.010$ & 0 \\
\hline \multicolumn{4}{|l|}{ Organic compound } \\
\hline Oil and grease $(\mathrm{mg} / \mathrm{L})$ & $<5.0$ & $<5.0$ & 0 \\
\hline \multicolumn{4}{|l|}{ Volatile organic compounds } \\
\hline Acrolein & $<100$ & $<100$ & 0 \\
\hline Acrylonitrile & $<100$ & $<100$ & 0 \\
\hline Benzene & $<5.0$ & $<5.0$ & 0 \\
\hline Bromoform & $<5.0$ & $<5.0$ & 0 \\
\hline Carbon tetrachloride & $<5.0$ & $<5.0$ & 0 \\
\hline Chlorobenzene & $<5.0$ & $<5.0$ & 0 \\
\hline Chlorodibromomethane & $<5.0$ & $<5.0$ & 0 \\
\hline Chloroethane & $<10$ & $<10$ & 0 \\
\hline 2-chloroethylvinyl ether & ND & ND & 0 \\
\hline Chloroform & $<5.0$ & $<5.0$ & 0 \\
\hline Dichlorobromomethane & $<5.0$ & $<5.0$ & 0 \\
\hline 1,1-dichloroethane & $<5.0$ & $<5.0$ & 0 \\
\hline 1,2-dichloroethane & $<5.0$ & $<5.0$ & 0 \\
\hline 1,1-dichloroethylene & $<5.0$ & $<5.0$ & 0 \\
\hline 1,2-dichloropropane & $<5.0$ & $<5.0$ & 0 \\
\hline 1,3-dichloropropylene & $<5.0$ & $<5.0$ & 0 \\
\hline Ethylbenzene & $<5.0$ & $<5.0$ & 0 \\
\hline Methyl bromide & $<10$ & $<10$ & 0 \\
\hline Methyl chloride & $<10$ & $<10$ & 0 \\
\hline Methylene chloride & $<5.0$ & $<5.0$ & 0 \\
\hline 1,1,2,2-tetrachloroethane & $<5.0$ & $<5.0$ & 0 \\
\hline Tetrachloroethylene & $<5.0$ & $<5.0$ & 0 \\
\hline Toluene & $<5.0$ & $<5.0$ & 0 \\
\hline 1,2-trans-dichloroethylene & $<5.0$ & $<5.0$ & 0 \\
\hline 1,1,1-trichloroethane & $<5.0$ & $<5.0$ & 0 \\
\hline 1,1,2-trichloroethane & $<5.0$ & $<5.0$ & 0 \\
\hline Trichloroethylene & $<5.0$ & $<5.0$ & 0 \\
\hline Vinyl chloride & $<10$ & $<10$ & 0 \\
\hline \multicolumn{4}{|l|}{ Acid organic compound } \\
\hline Phenols, total (mg/L) & $<0.0050$ & $<0.0050$ & 0 \\
\hline
\end{tabular}

These quality-control tests provided an indication of precision and accuracy. Precision is the measure of the variability of individual sample measurements and was calculated as follows:

$$
P=\frac{|C-D|}{0.5(C+D)} \times 100
$$

where

$P=$ precision of the measurement pair, in percent;

$C=$ concentration in the field sample; and

$D=$ concentration in the field-sample replicate.

Accuracy is the measure of system bias or the difference between the true concentration of the sample and the measured concentration of the sample and was calculated as follows:

$$
A=\frac{M C}{A C} \times 100
$$

where

$A=$ accuracy of the determination, in percent;

$M C=$ measured concentration in the sample; and

$A C=$ actual concentration in the sample.

Control limits for precision range from 0 (identical duplicate control sample results) to the average historical relative percent difference plus three standard deviation units. Control limits for accuracy are based on the average historical percent recovery plus or minus three standard deviation units.

The quality-control tests for the method blanks, duplicate control samples, matrix spikes, and duplicate matrix spikes were acceptable with a few exceptions (which did not include any constituents or properties for which loads were calculated). There were detections on the method blanks for one property (specific conductance), one volatile organic compound (methylene chloride), and one base/neutral organic compound (di-n-butyl phthalate). The precision control limits were exceeded in the duplicate control samples for one volatile organic compound (2-chloroethylvinyl ether), five base/neutral organic compounds (benzidine, 3,4-benzofluoranthene, benzo $(\mathrm{K})$ fluoranthene, diethyl phthalate, and dimenthyl phthalate), and two pesticides (endosulfan sulfate and endrin aldehyde). The accuracy control limits were exceeded in the duplicate control samples for two base/neutral organic compounds (benzidine and hexachlorocyclopentadiene) and one pesticide (heptachlor). The specific results for these quality-control procedures are on file at Quanterra Environmental Services. 


\section{CHARACTERIZATION OF STORMWATER RUNOFF}

Stormwater runoff was sampled and precipitation recorded at the three representative stormwaterrunoff sites during May through September 1995 and May through July 1996. Runoff from six representative storm events (table 1) was collected during this period. Twelve sets of stormwater runoff samples were collected during these storm events, four at each site (table 10). Nine sets of stormwater runoff samples had complete analyses done. One additional partial sample from each site also was collected but had incomplete analyses due to difficulties encountered in shipping and meeting constituent holding times. However, the analyses that were completed for the additional partial samples were acceptable and were reported and used in all calculations of loads and event-mean concentrations. The date and duration of the storm events sampled, the amount of rainfall that fell immediately before and during the sampled discharge, and the time between the storm events sampled and the end of the previous measurable storm events are listed in table 10. The elapsed dry period (period preceding sampling where there were no storms of greater than $0.10 \mathrm{inch}$ ) ranged from 72 to 317 hours at the three sites. If runoff from the storm events continued for more than 3 hours, samples were collected during the initial 3 hours of runoff; otherwise, runoff from the entire event was sampled. Rainfall amounts associated with sampled discharges ranged from 0.16 to 0.69 inch. For comparison, the total amount of rainfall for the events that were sampled ranged from 0.16 to 0.75 inch. All sampled events comply with the intent of USEPA requirements for rainfall amounts and durations between measurable storm events (U.S. Environmental Protection Agency, 1990).

\section{Description of Sampled Storms}

Grab samples for analysis of selected constituents or properties (see tables 6 and 7) typically were collected manually by USGS personnel during the first hour after initial rise of stream stage; discrete samples for later flow-weighted compositing were collected at 15-minute intervals either by automatic sampler or manually by USGS personnel. Gage heights, discharges, and rainfall during the storms are shown in figures 6-8 for four sets of stormwater samples from the representative storm events collected at each of the three monitoring sites (commercial, industrial, and residential, respectively).

Table 10. Characteristics of stormwater runoff sampled during 1995-96 in Sioux Falls

[Total rainfall, total rainfall in inches for the entire storm event; Elapsed dry period, time between the storm event sampled and the previous measurable storm event of greater than 0.1 inch]

\begin{tabular}{|c|c|c|c|c|c|c|}
\hline $\begin{array}{l}\text { Sampling-site } \\
\text { reference } \\
\text { number }\end{array}$ & $\begin{array}{l}\text { Predominant } \\
\text { land use }\end{array}$ & $\begin{array}{c}\text { Beginning of } \\
\text { storm } \\
\text { (date/time) }\end{array}$ & $\begin{array}{l}\text { End of storm } \\
\text { (date/time) }\end{array}$ & $\begin{array}{c}\text { Rainfall during } \\
\text { sampling } \\
\text { (inches) }\end{array}$ & $\begin{array}{c}\text { Total rainfall } \\
\text { (inches) }\end{array}$ & $\begin{array}{c}\text { Elapsed dry } \\
\text { period } \\
\text { (hours) }\end{array}$ \\
\hline \multirow[t]{3}{*}{1} & Commercial & $6-23-95 / 0025^{1}$ & $6-23-95 / 0343$ & 0.19 & 0.19 & 313.7 \\
\hline & & $5-3-96 / 1253$ & $5-3-96 / 1852$ & 0.23 & 0.24 & 286.1 \\
\hline & & $7-3-96 / 1256$ & $7-3-96 / 1416$ & 0.16 & 0.16 & 249.2 \\
\hline \multirow[t]{4}{*}{2} & Industrial & $5-7-95 / 1800$ & $5-8-95 / 1210$ & 0.22 & 0.37 & 85.3 \\
\hline & & $6-23-95 / 0030^{1}$ & $6-23-95 / 0653$ & 0.29 & 0.30 & 317.2 \\
\hline & & $9-18-95 / 1715$ & $9-19-95 / 0905$ & 0.55 & 0.63 & 316.9 \\
\hline & & $5-3-96 / 1300$ & $5-3-96 / 1840$ & 0.23 & 0.23 & 286.4 \\
\hline \multirow{2}{*}{3} & & $5-3-96 / 1245$ & $5-3-96 / 1819$ & 0.24 & 0.25 & 286.2 \\
\hline & & $7-3-96 / 1305$ & $7-3-96 / 1411$ & 0.18 & 0.18 & 249.5 \\
\hline
\end{tabular}

\footnotetext{
${ }^{1}$ Incomplete analyses.
} 

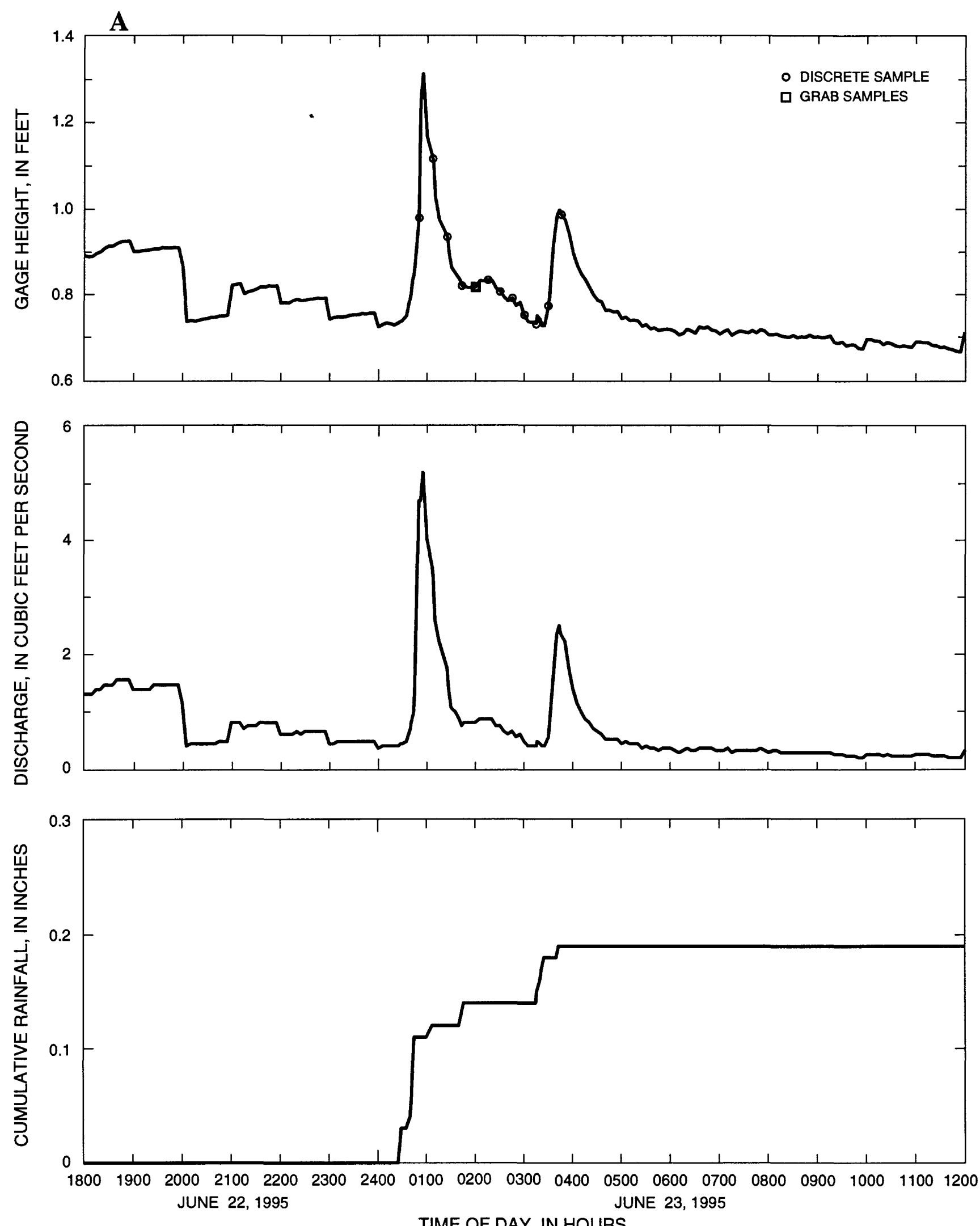

TIME OF DAY, IN HOURS

Figure 6. Gage height, discharge, and cumulative rainfall for the storm events sampled at the commercial site. 

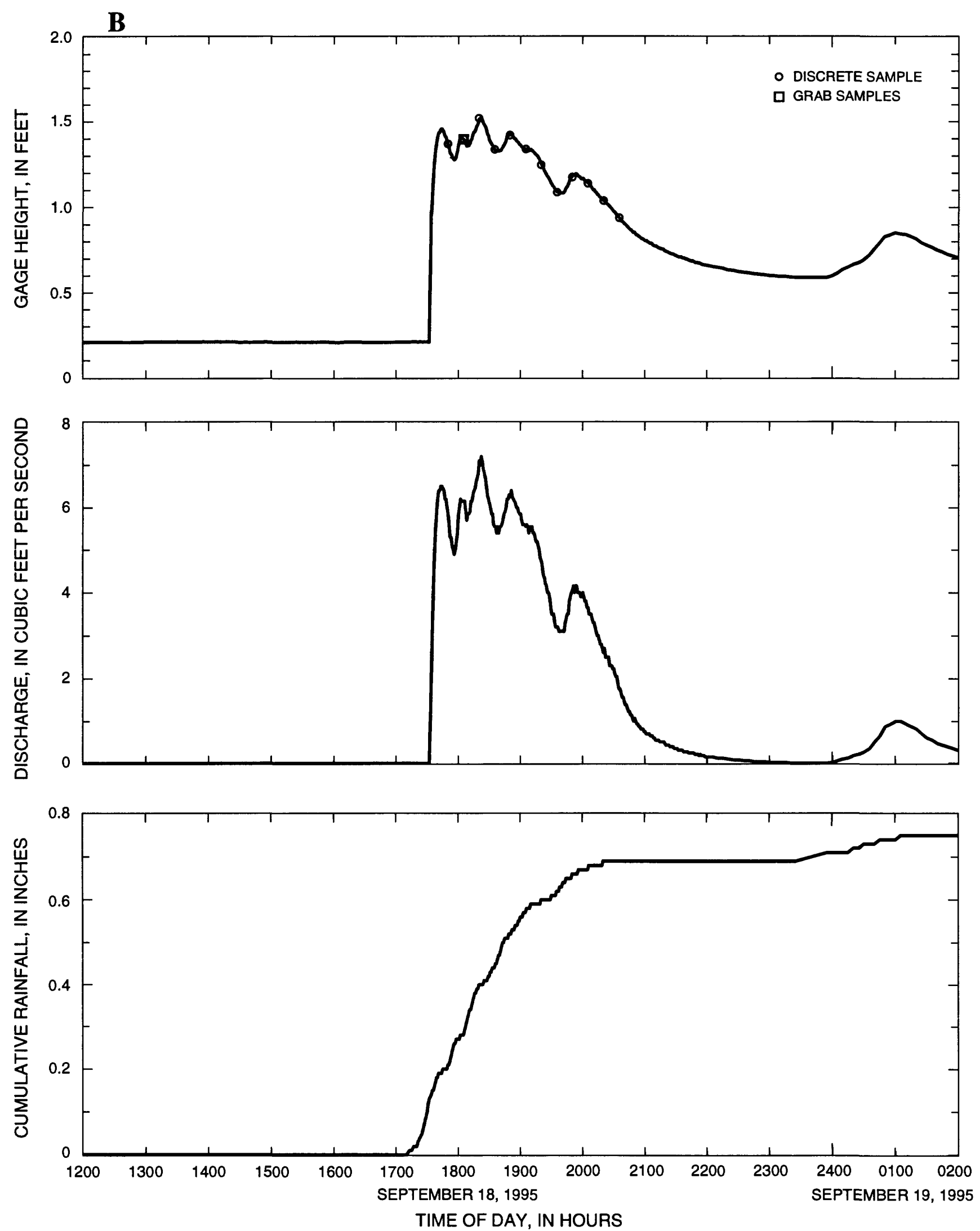

Figure 6. Gage height, discharge, and cumulative rainfall for the storm events sampled at the commercial site.-Continued 

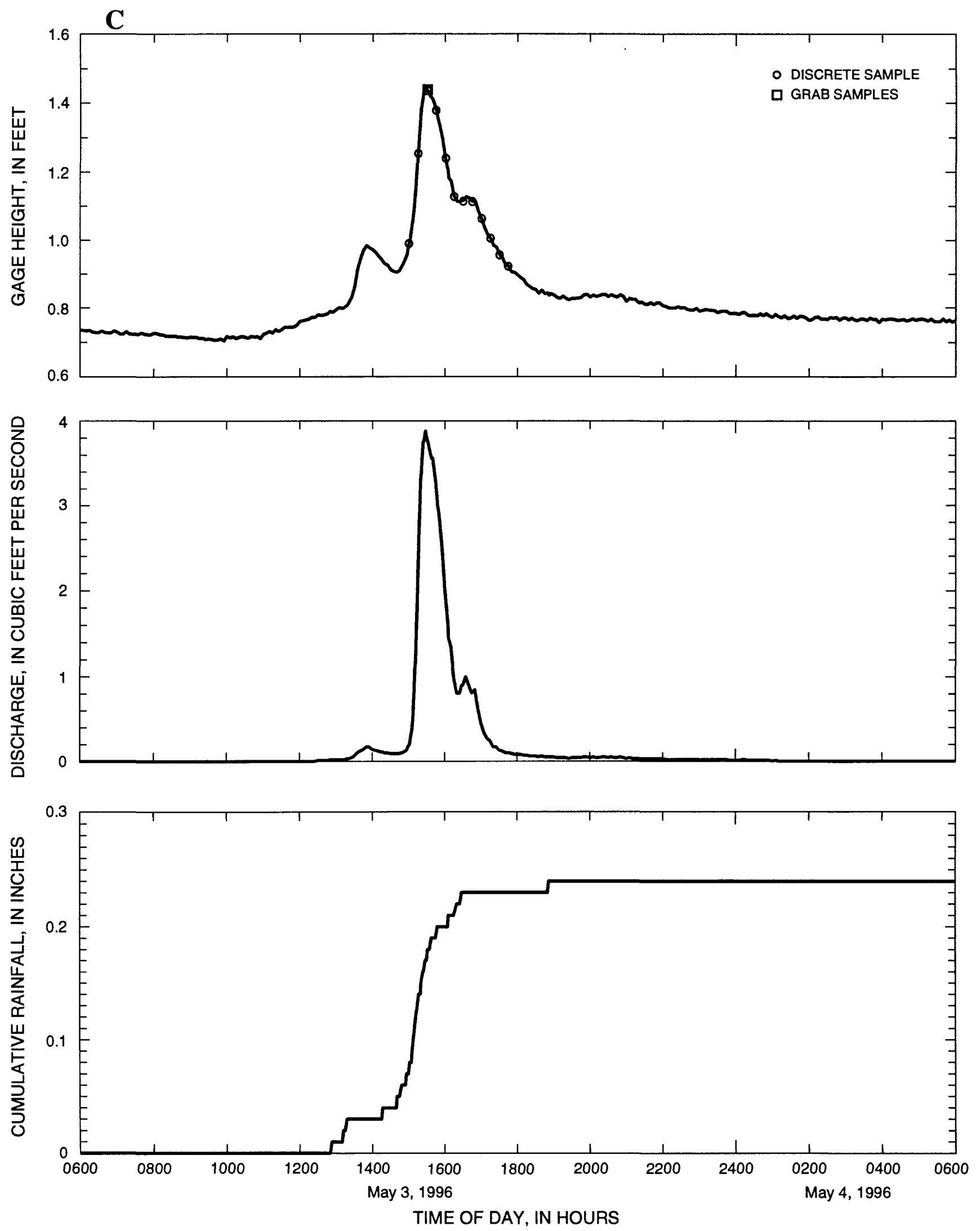

Figure 6. Gage height, discharge, and cumulative rainfall for the storm events sampled at the commercial site.-Continued 

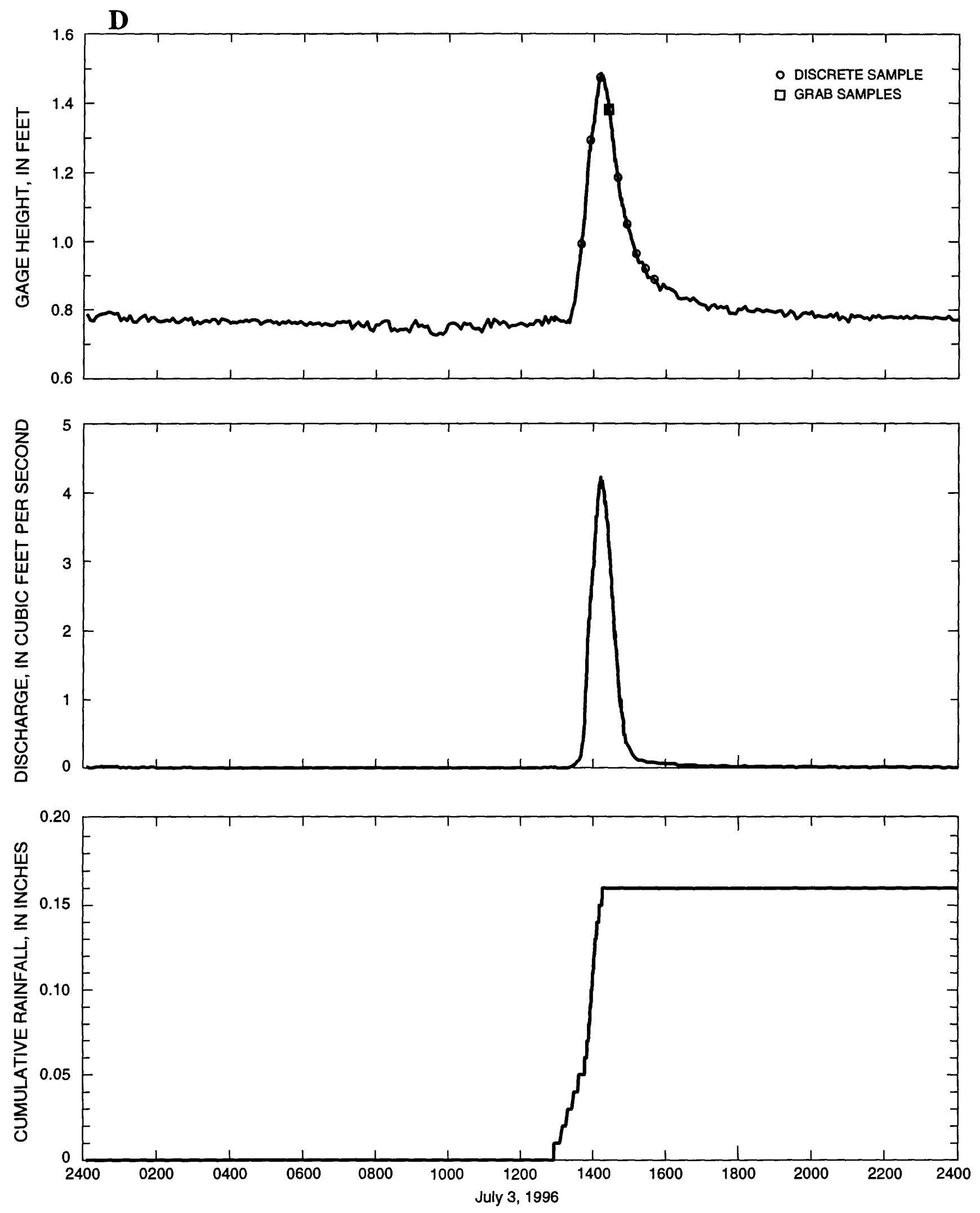

TIME OF DAY, IN HOURS

Figure 6. Gage height, discharge, and cumulative rainfall for the storm events sampled at the commercial site.-Continued 

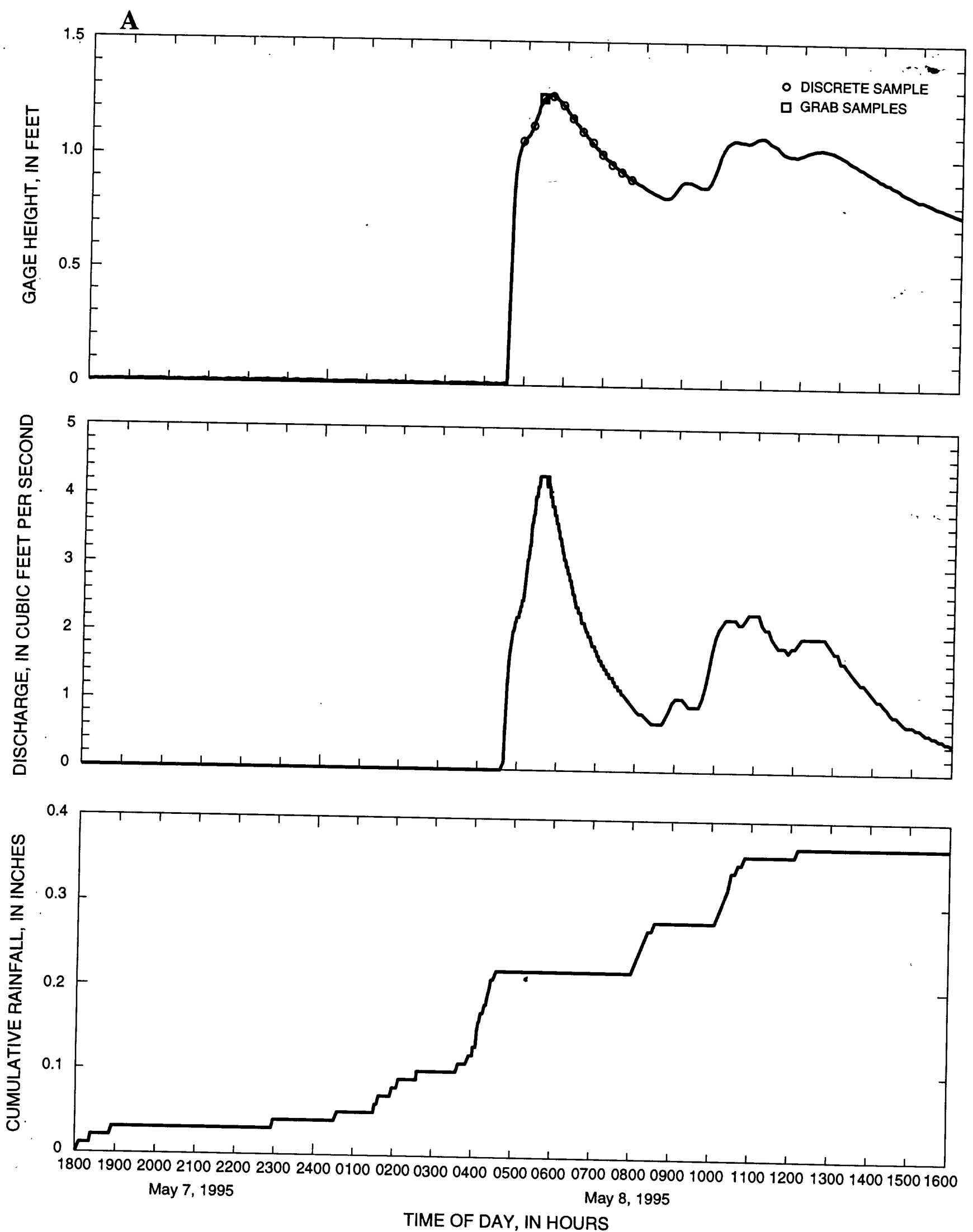

Figure 7. Gage height, discharge, and cumulative rainfall for the storm events sampled at the industrial site. 

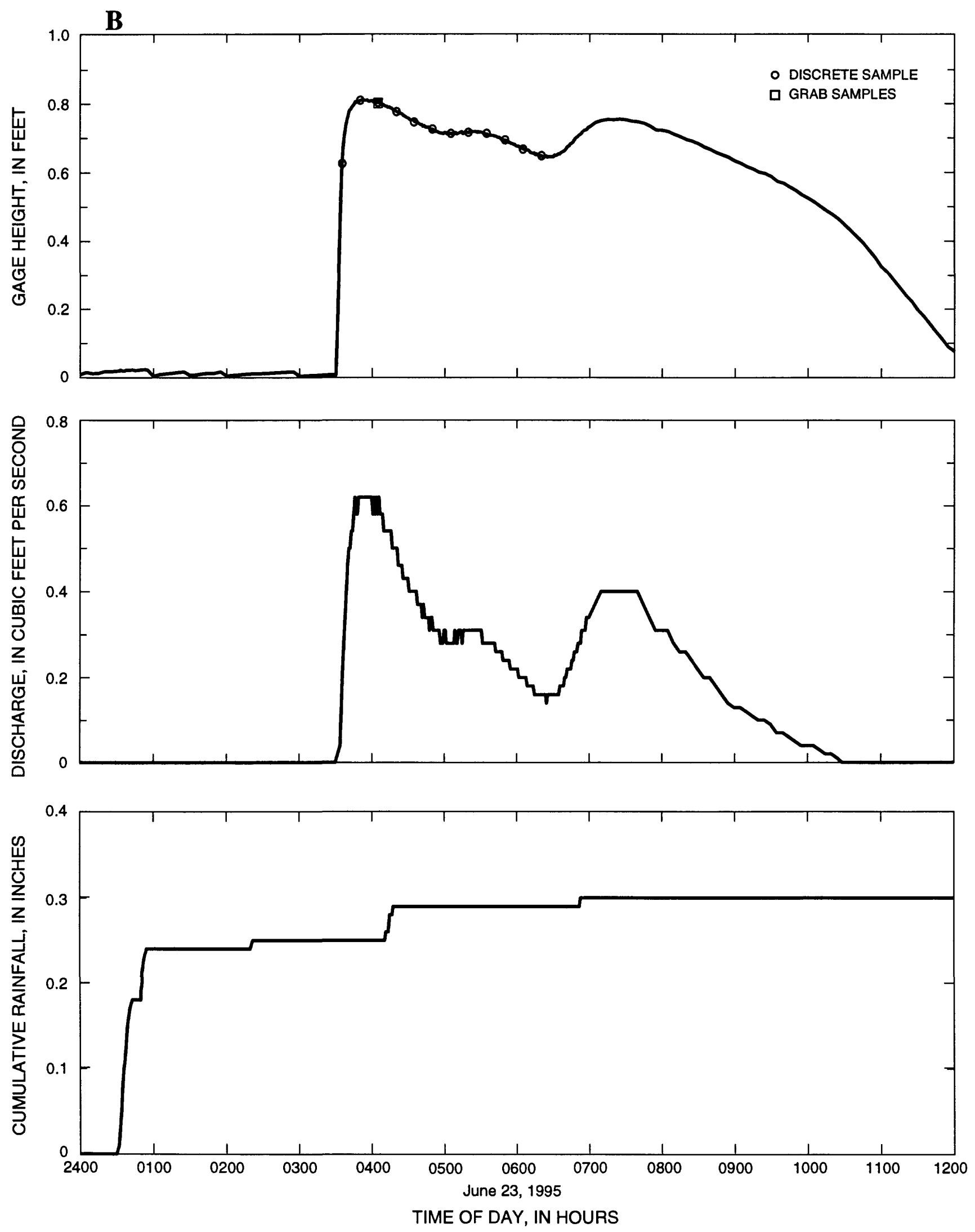

Figure 7. Gage height, discharge, and cumulative rainfall for the storm events sampled at the industrial site.--Continued 

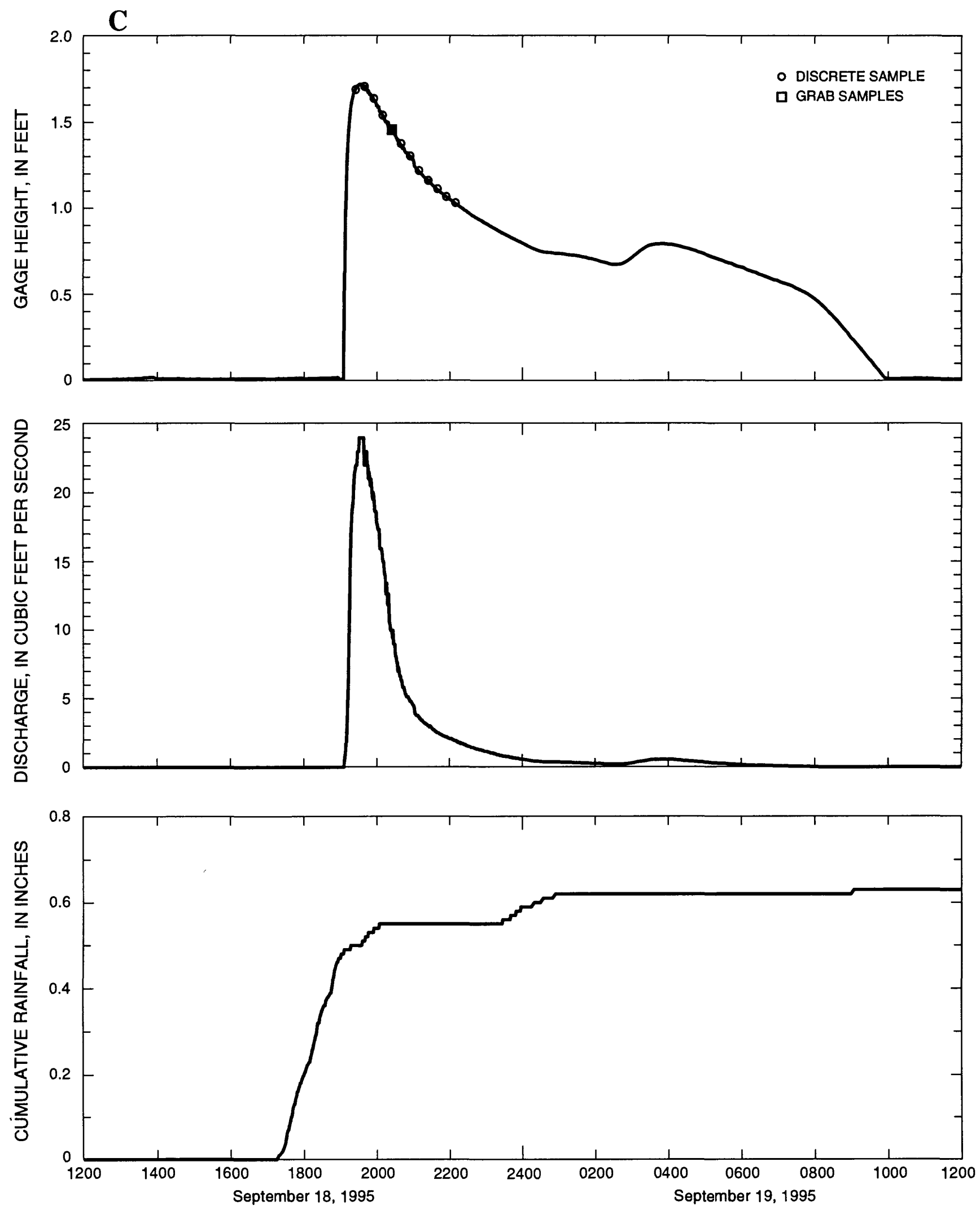

TIME OF DAY, IN HOURS

Figure 7. Gage height, discharge, and cumulative rainfall for the storm events sampled at the industrial site.--Continued 

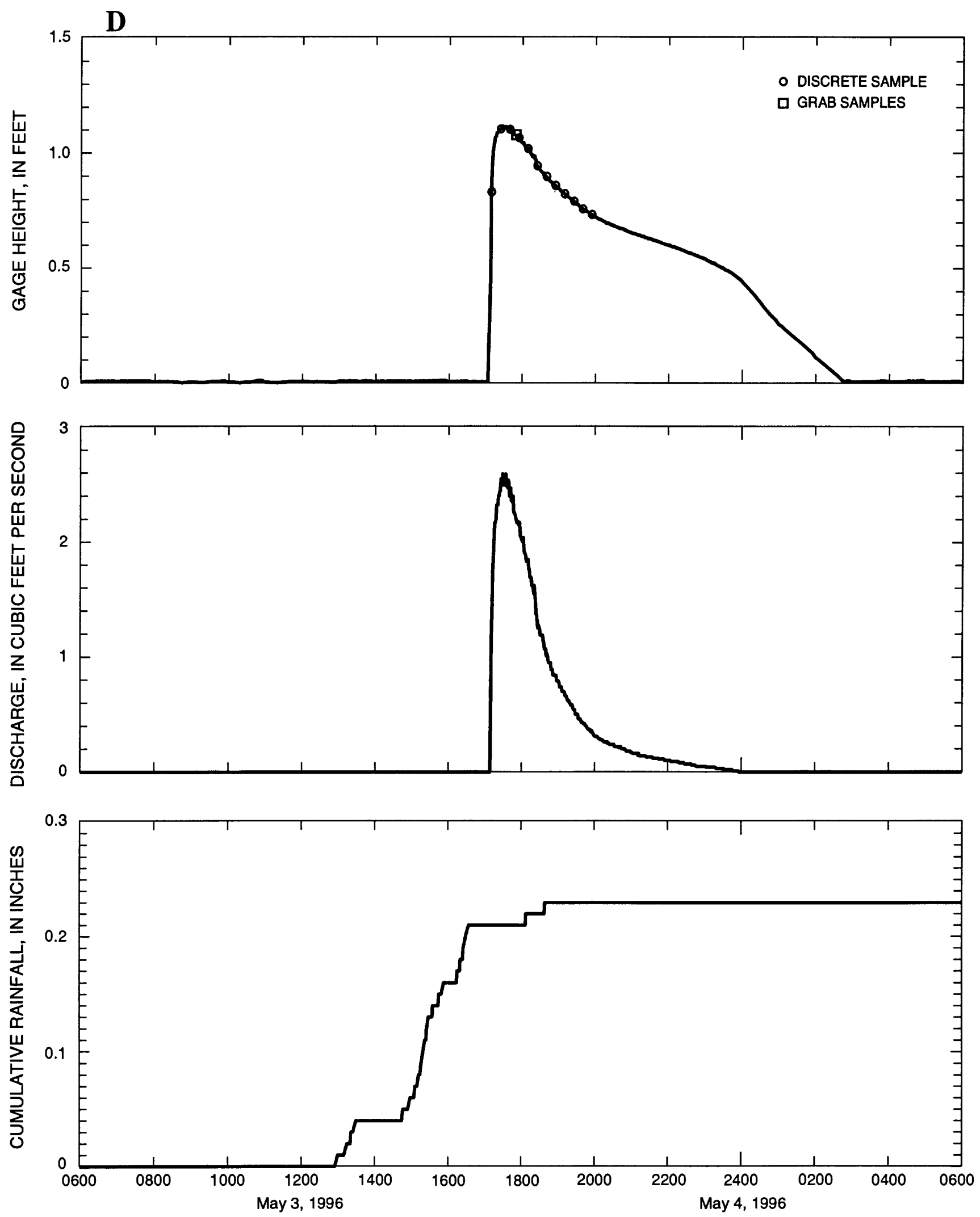

TIME OF DAY, IN HOURS

Figure 7. Gage height, discharge, and cumulative rainfall for the storm events sampled at the industrial site.--Continued 

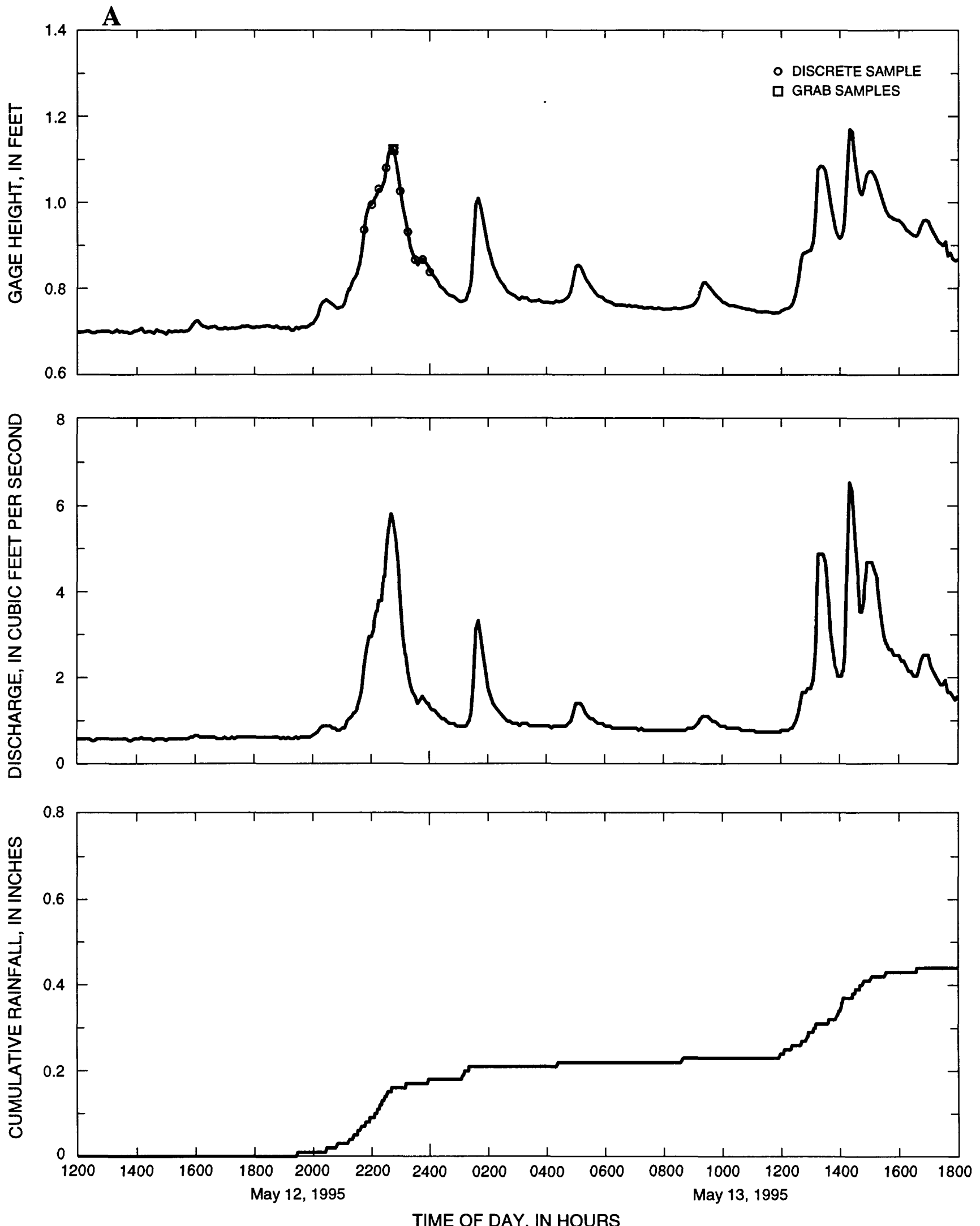

Figure 8. Gage height, discharge, and cumulative rainfall for the storm events sampled at the residential site.

36

Characterization of Stormwater Runoff in Sioux Falls, South Dakota, 1995-96 

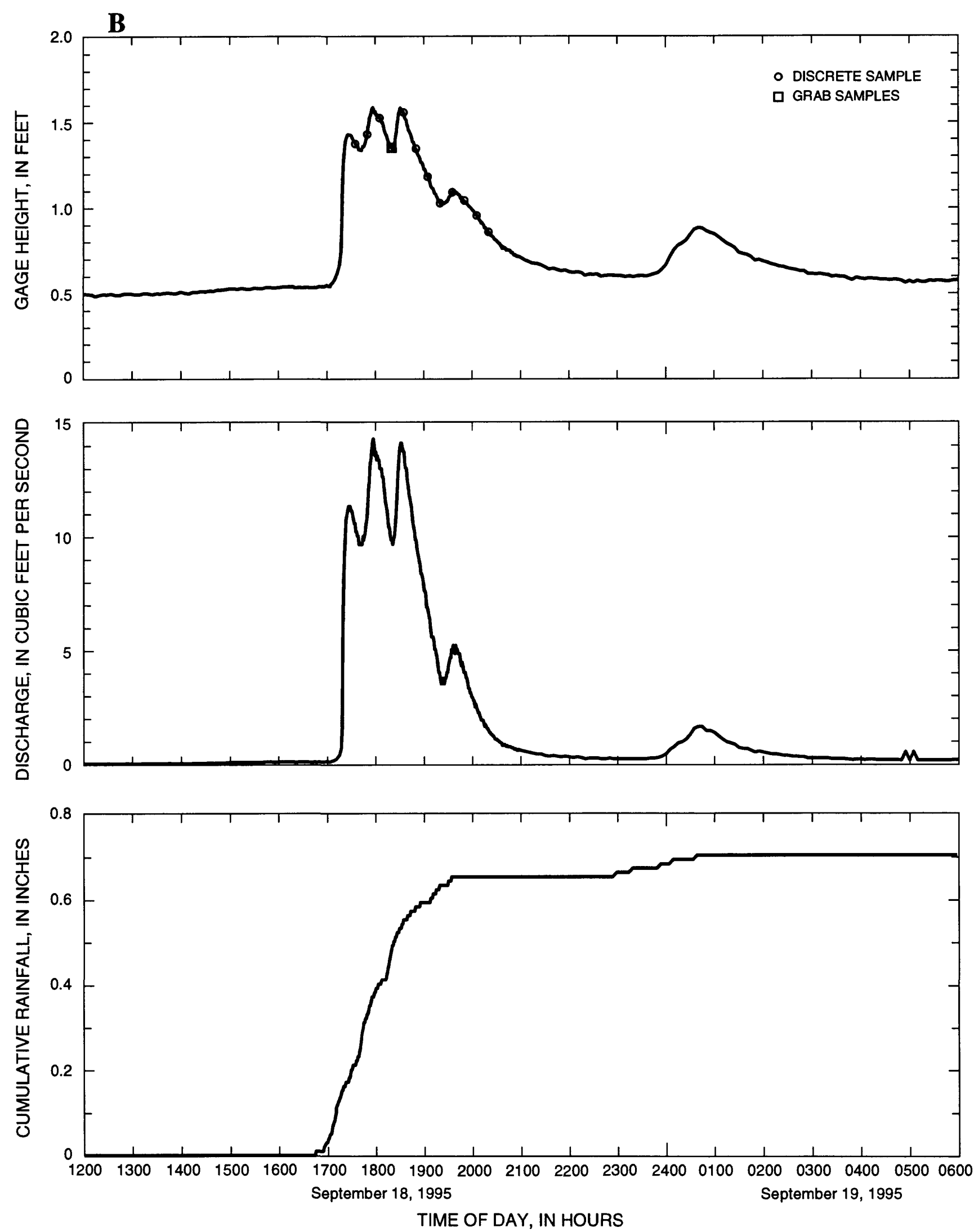

Figure 8. Gage height, discharge, and cumulative rainfall for the storm events sampled at the residential site.-Continued 

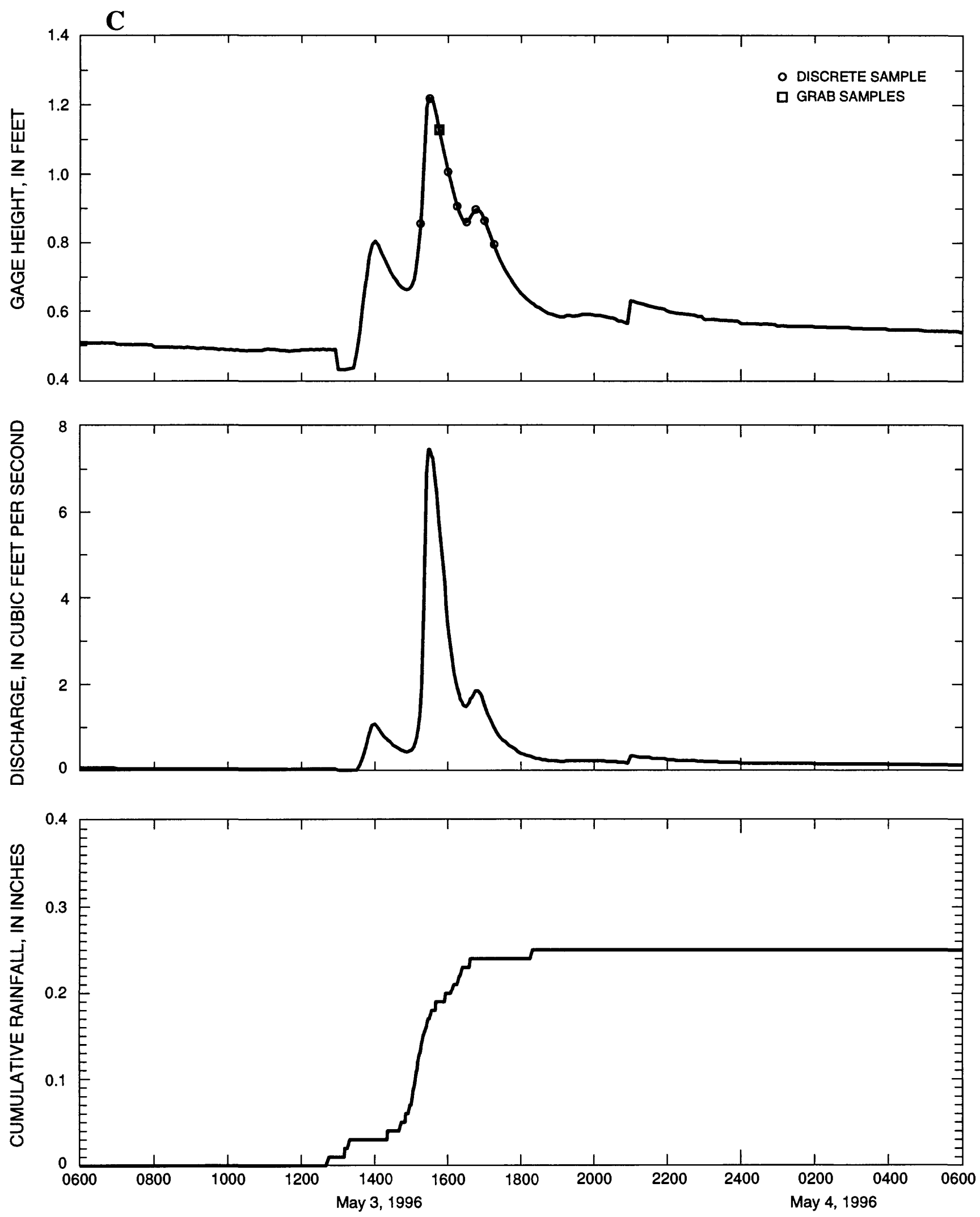

TIME OF DAY, IN HOURS

Figure 8. Gage height, discharge, and cumulative rainfall for the storm events sampled at the residential site.-Continued 

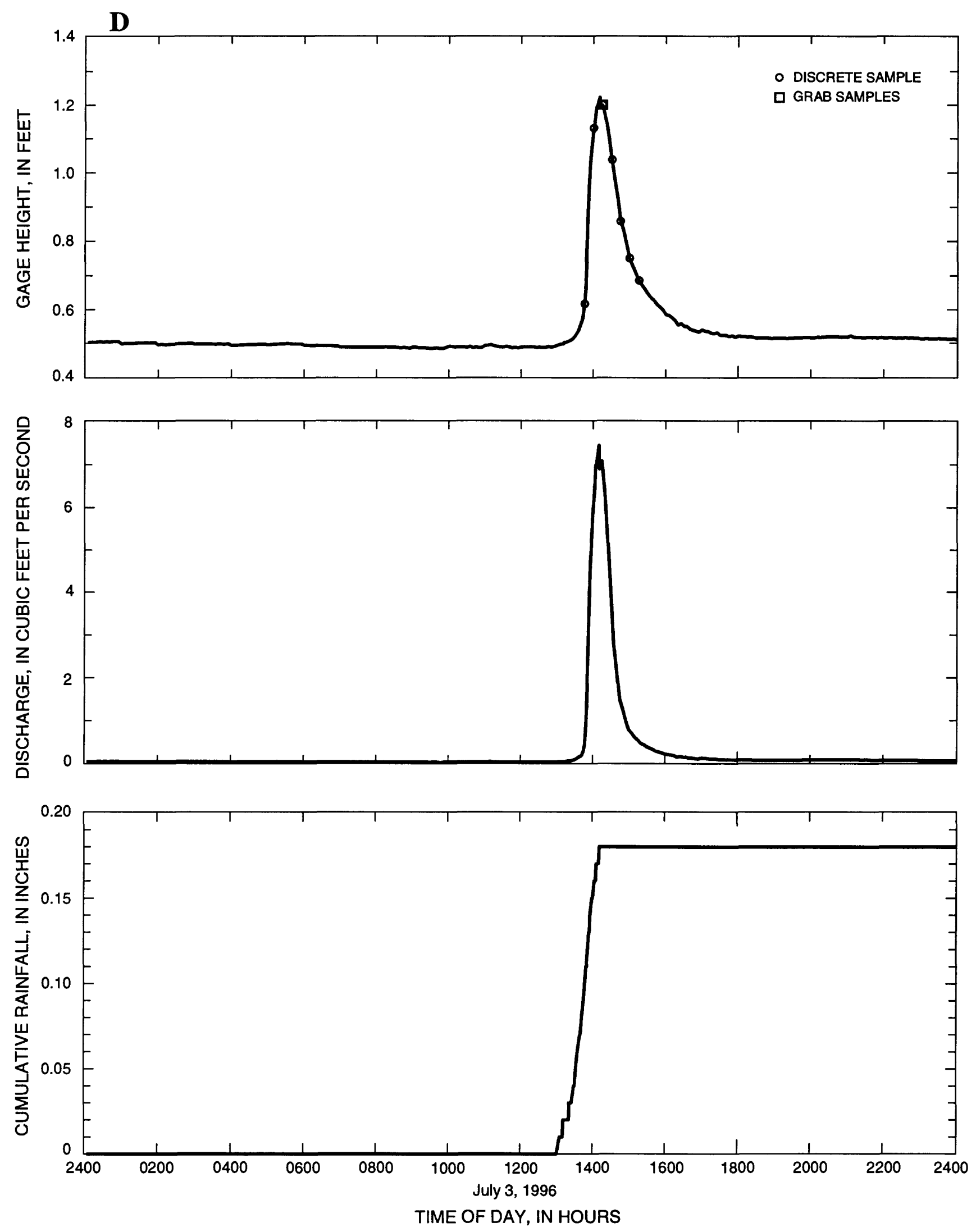

Figure 8. Gage height, discharge, and cumulative rainfall for the storm events sampled at the residential site.-Continued 
On May 8, 1995, stormwater runoff was sampled at the industrial site. The other two sites did not receive sufficient rainfall to meet the representative-storm criteria. Grab samples were collected near the peak discharge, about 45 minutes after the initial rise in stage (fig. 7A). Discrete samples were collected using the automatic sampler for the first three samples, and then manually by USGS personnel for the remaining sampling time, which totaled 3 hours. Total rainfall at the end of all sampling at the site was 0.22 inch, and total rainfall for the entire storm was $0.37 \mathrm{inch}$. It took more than 5 hours from the time the rainfall began until the runoff reached the sampling site. No water or flow was at the site prior to the start of the storm event. The site had an initial peak discharge followed by a smaller secondary peak discharge about 5 hours later. All of the samples (grab and discrete) were collected near the initial peak. More than 80 hours had passed since the last storm event of greater than 0.1 inch of rainfall at the site.

Runoff produced from a storm that began on May 12, 1995, was sampled at the residential site. Grab samples were collected near the peak discharge, about 75 minutes after the initial major rise in stage at this site (fig. 8A). Discrete samples were collected using the automatic sampler for the first three samples, and then manually for the remaining sampling time, which totaled 3 hours. Total rainfall at the end of all sampling at the site was 0.18 inch, and total rainfall for the entire storm was 0.22 inch. About 0.50 cubic foot per second of flow was at the site prior to the start of the storm runoff. Seventy-two hours had passed since the last storm event of greater than 0.1 inch of rainfall at the site.

On June 23, 1995, runoff from 0.19- and 0.29 -inch storm events was sampled at the commercial and industrial sites, respectively. The grab samples were collected at the commercial site 85 minutes and at the industrial site 31 minutes after the initial rise in stage (figs. 6A and 7B). The collection of the grab samples at the commercial site was delayed until water from a stagnant pool at the site was sufficiently flushed in order to obtain a representative sample of the initial flush from the basin. The discrete samples were collected manually every 15 minutes for 3 hours. Both sites had initial-peak discharges followed by smaller secondary-peak discharges about 3 hours later. Samples at the commercial site were collected near both peaks. All samples at the industrial site were collected near the initial peak. The commercial site had about
0.5 cubic foot per second of flow prior to the storm event, and it took only about 10 minutes from the start of rainfall until the initial rise in stage at this sampling site. In contrast, it took more than 3 hours from the time the majority of the rainfall started until the runoff reached the industrial sampling site. No flow was at the industrial site prior to the start of the storm event. It had been more than 300 hours since the last storm event of greater than 0.1 inch of rainfall at either site.

Runoff from rainfall on September 18, 1995, was sampled at all three sites. Grab samples were collected 30,75 , and 60 minutes after the initial major rise in stage at the commercial, industrial, and residential sites, respectively (figs. 6B, 7C, and 8B). The automatic sampler collected the initial three discrete samples at each site, with the remainder of the discrete samples collected manually. Total rainfall at the end of all sampling was $0.69,0.55$, and 0.65 inch, and total rainfall for the entire storm was $0.75,0.63$, and 0.70 inch at the commercial, industrial, and residential sites, respectively. Because almost all of the rainfall fell in a 3-hour period and at a nearly constant rate, all three sites had a single peak discharge from this storm event. The commercial site had a stagnant pool prior to the event; no water or flow was at the industrial or residential sites prior to the start of the storm event. It took about 20 and 30 minutes from the start of the rainfall until the initial rise in stage at the commercial and residential sampling sites, respectively. It took about 2 hours from the time the rainfall started until the runoff reached the industrial sampling site. More than 300 hours had passed since the last storm event of greater than 0.1 inch of rainfall at any of the sites.

On May 3, 1996, stormwater runoff was sampled at all three sites. Grab samples were collected 45, 40, and 45 minutes after the initial main rise in stage at the commercial, industrial, and residential sites, respectively (figs. 6C, 7D, and 8C). The discrete samples at the commercial and residential sites were collected manually. The automatic sampler collected the four initial discrete samples at the industrial site, with the remainder of the samples collected manually. Total rainfall at the end of all sampling was $0.23,0.23$, and 0.24 inch at the commercial, industrial, and residential sites, respectively. Almost all of the rainfall at the sites fell in a 3-hour period and at a nearly constant rate. Consequently, all three sites had a single peak discharge from this storm event. Although all sites had no flow prior to the storm event, the commercial and residential sites did have small stagnant pools prior to the 
event. More than 250 hours had passed since the last storm event of greater than 0.1 inch of rainfall at any of the sites.

On July 3, 1996, runoff from 0.16- and 0.18-inch storm events was sampled at the commercial and residential sites, respectively (figs. 6D and 8D). Grab samples were collected at the commercial site 65 minutes and at the residential site 45 minutes after the initial rise in stage. The automatic sampler collected the four initial discrete samples at the commercial site, with the remainder of the samples collected manually. All the discrete samples at the residential site were collected manually. Because almost all of the rainfall fell in a 1-hour period and at a nearly constant rate at both sites, a single peak discharge occurred at each site. Although both sites had little or no flow prior to the storm event, the sites did have small stagnant pools prior to the event. Almost 250 hours had passed since the last storm event of greater than 0.1 inch of rainfall at each of the sites. Ordinarily, rainfall totals of 0.16 and 0.18 inch would have been considered too small to meet the representative-storm criteria of 50 percent of the median storm amount. However, because of time restrictions relating to obtaining a permit for the City of Sioux Falls, the SDDENR accepted samples from these storms. The SDDENR approved sampling from these storms, reasoning that the storms in question were both greater than 0.10 inch and had adequate runoff available for sampling.

\section{Concentrations of Selected Constituents or Properties in Stormwater Runoff}

Laboratory analyses of nearly 150 constituents or properties including chemical and biochemical oxygen demands, bacteria, major ions, dissolved and suspended solids, nutrients, metals and trace elements, cyanide, and organics (volatile, base/neutral, acid, and pesticide compounds) required by the sampling program were performed by Quanterra Environmental Services in Arvada, Colorado, or by the USGS in Huron, South Dakota. Field and laboratory results for the grab-collected samples for each sampling site are presented in table 11 and include data for bacteria, cyanide, oil and grease, VOC's, and total phenols. Oil and grease was detected at the residential site. Only one VOC was detected out of 28 VOC's that were analyzed. The VOC methylene chloride was detected at a level slightly above the method reporting limit at the commercial site. Total phenols were detected at all three sites at a level slightly above the method reporting limit.

High levels of bacteria (total coliform, fecal coliform, and fecal streptococcus) were found at all three sites. The total coliform count per $100 \mathrm{~mL}$ ranged from 3,400 to $34,000,>4,000$ to 87,330 , and 14,000 to 89,333 at the commercial, industrial, and residential sites, respectively. The fecal coliform count per $100 \mathrm{~mL}$ ranged from 250 to $6,100,2,300$ to 4,800 , and 1,800 to 24,000 at the commercial, industrial, and residential sites, respectively. The fecal streptococcus count per $100 \mathrm{~mL}$ ranged from 4,000 to $43,000,20,000$ to 93,000 , and 9,200 to 68,000 at the commercial, industrial, and residential sites, respectively.

The data for the flow-weighted composite samples are presented in table 12 for each sampling site. Chemical oxygen demand ranged from 22 to $126,25.1$ to 47.8 , and 24.3 to $115 \mathrm{mg} / \mathrm{L}$ (milligrams per liter), and biochemical oxygen demand ranged from 8 to $51.2,4.5$ to 51.7 , and 7 to $17.7 \mathrm{mg} / \mathrm{L}$ at the commercial, industrial, and residential sites, respectively. Total nitrogen ranged from 1.22 to $4.0,<1.04$ to 4.43 , and 2.74 to $5.85 \mathrm{mg} / \mathrm{L}$, and dissolved solids ranged from 37 to 396,116 to 280 , and 119 to $287 \mathrm{mg} / \mathrm{L}$ at the commercial, industrial, and residential sites, respectively.

There were detections of the metals arsenic, chromium, copper, lead, and zinc. Arsenic was detected at a level slightly above the method reporting limit $(0.0050 \mathrm{mg} / \mathrm{L})$ at the commercial and industrial sites. Chromium, copper, and zinc were detected at all three sites. Lead was detected at a level slightly above the method reporting limit $(0.050 \mathrm{mg} / \mathrm{L})$ at the industrial site.

Total petroleum hydrocarbons were detected at all three sites and ranged from $<1.0$ to $2.0,1.7$ to 7.3 , and $<1.0$ to $8.4 \mathrm{mg} / \mathrm{L}$ at the commercial, industrial, and residential sites, respectively. There were no detections in any of the sampled runoff at the three sites for the base/neutral or acid organic compounds. The pesticides aldrin and gamma BHC were detected at levels slightly above the method reporting limits at the industrial site, and diazinon was detected at the residential site. The other 23 pesticides that were analyzed were not detected at any of the sites. A summary of constituents or properties detected in stormwater runoff from sampling sites in Sioux Falls is shown in table 13. 


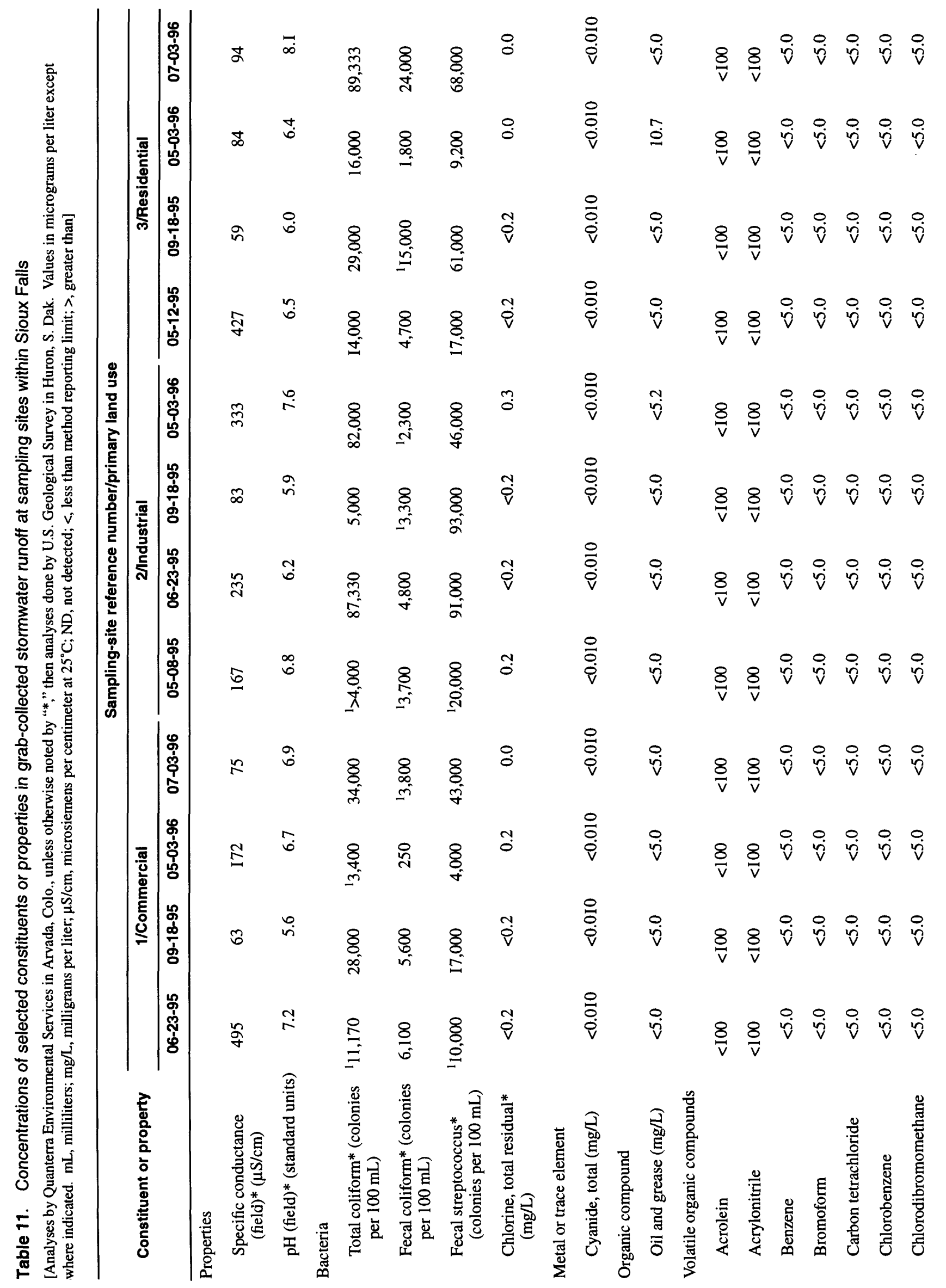




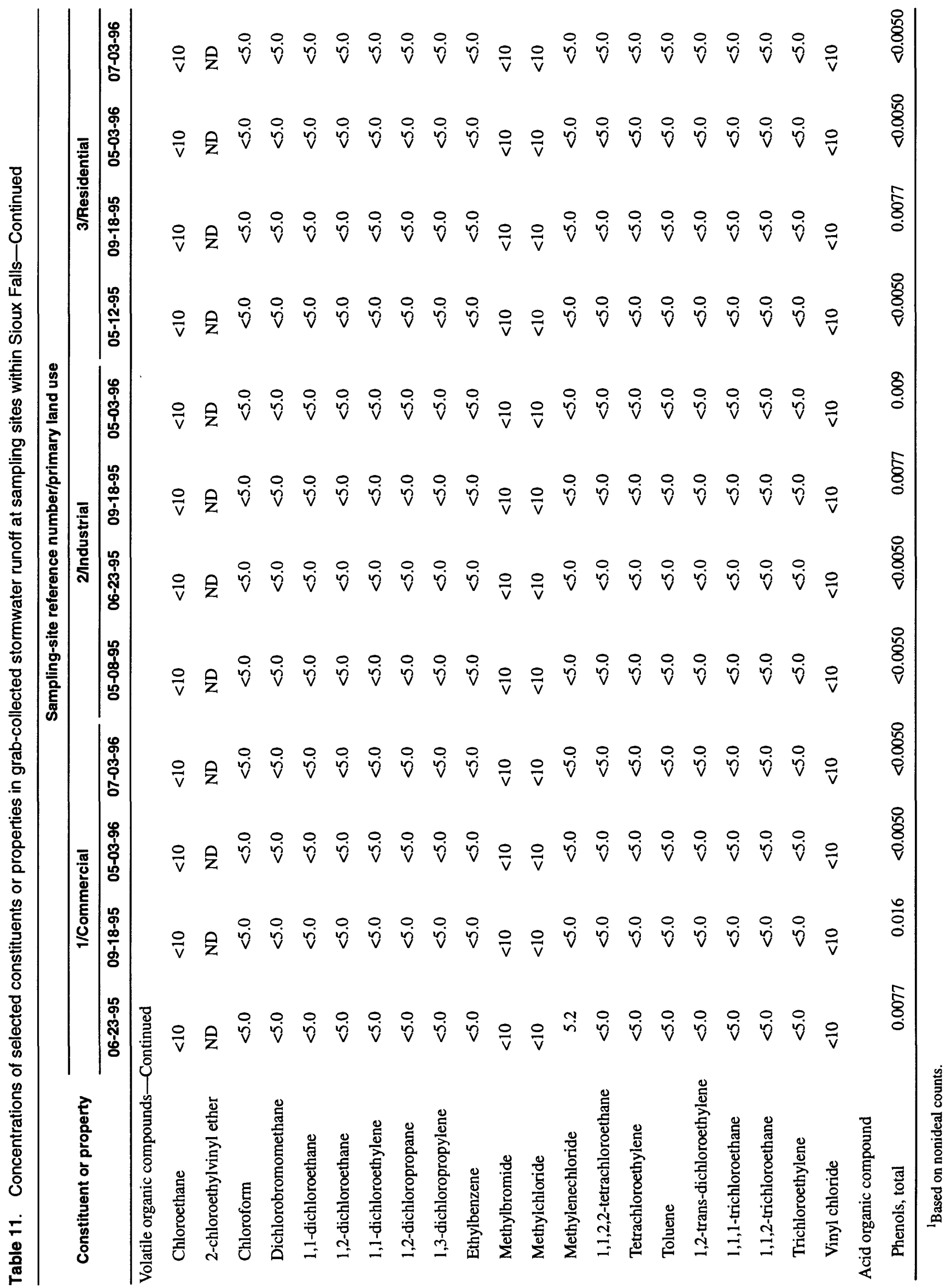




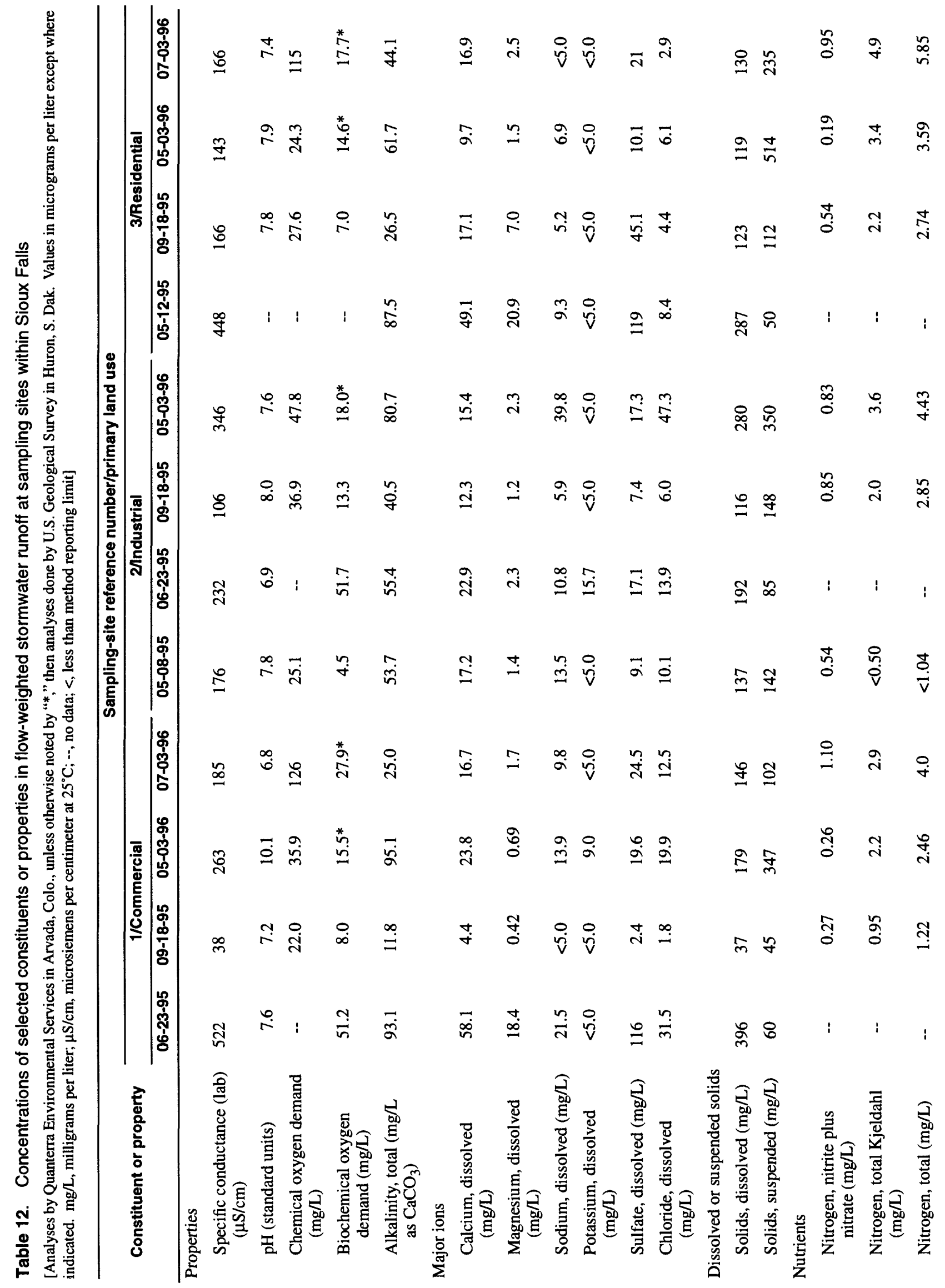




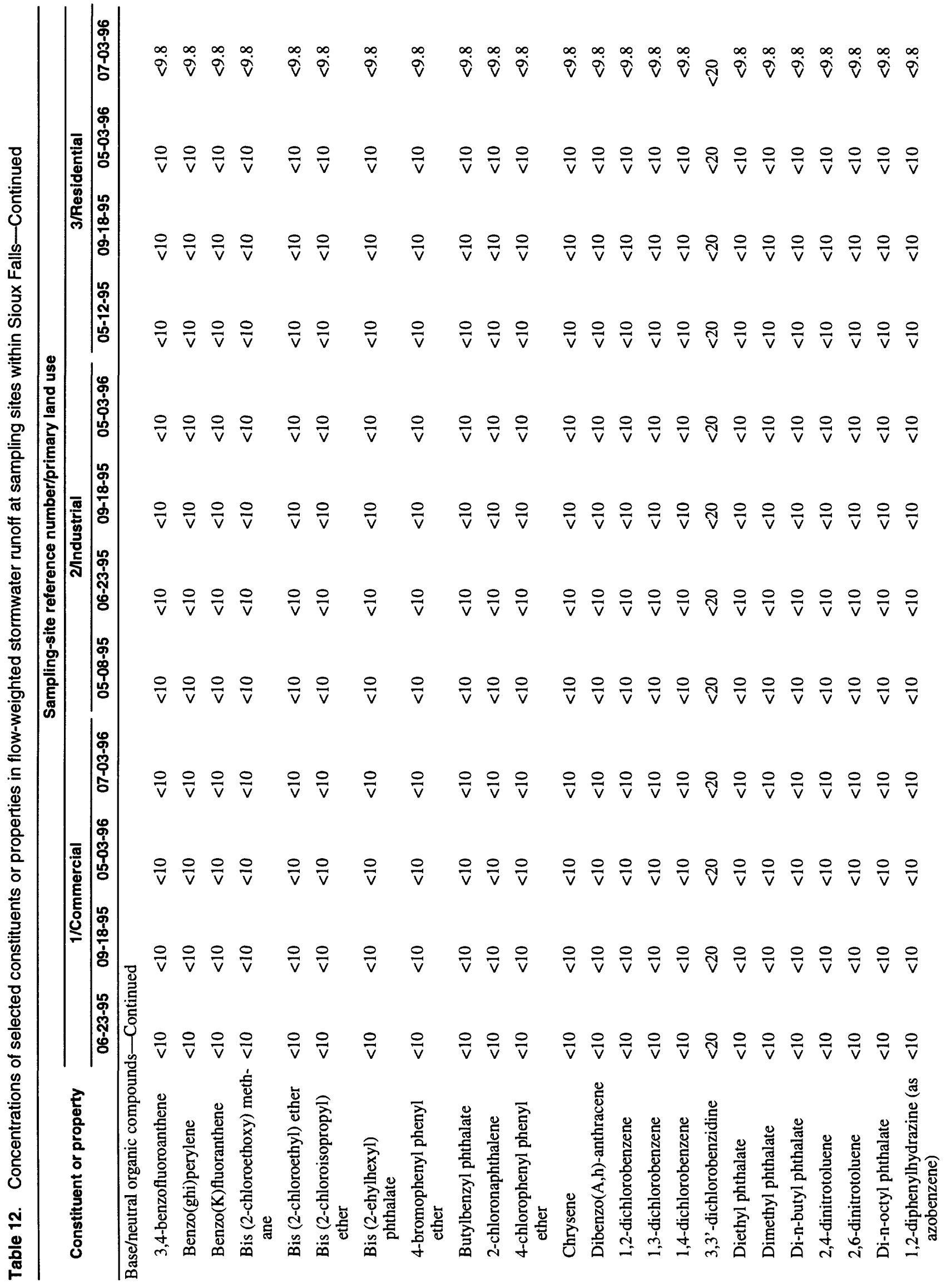




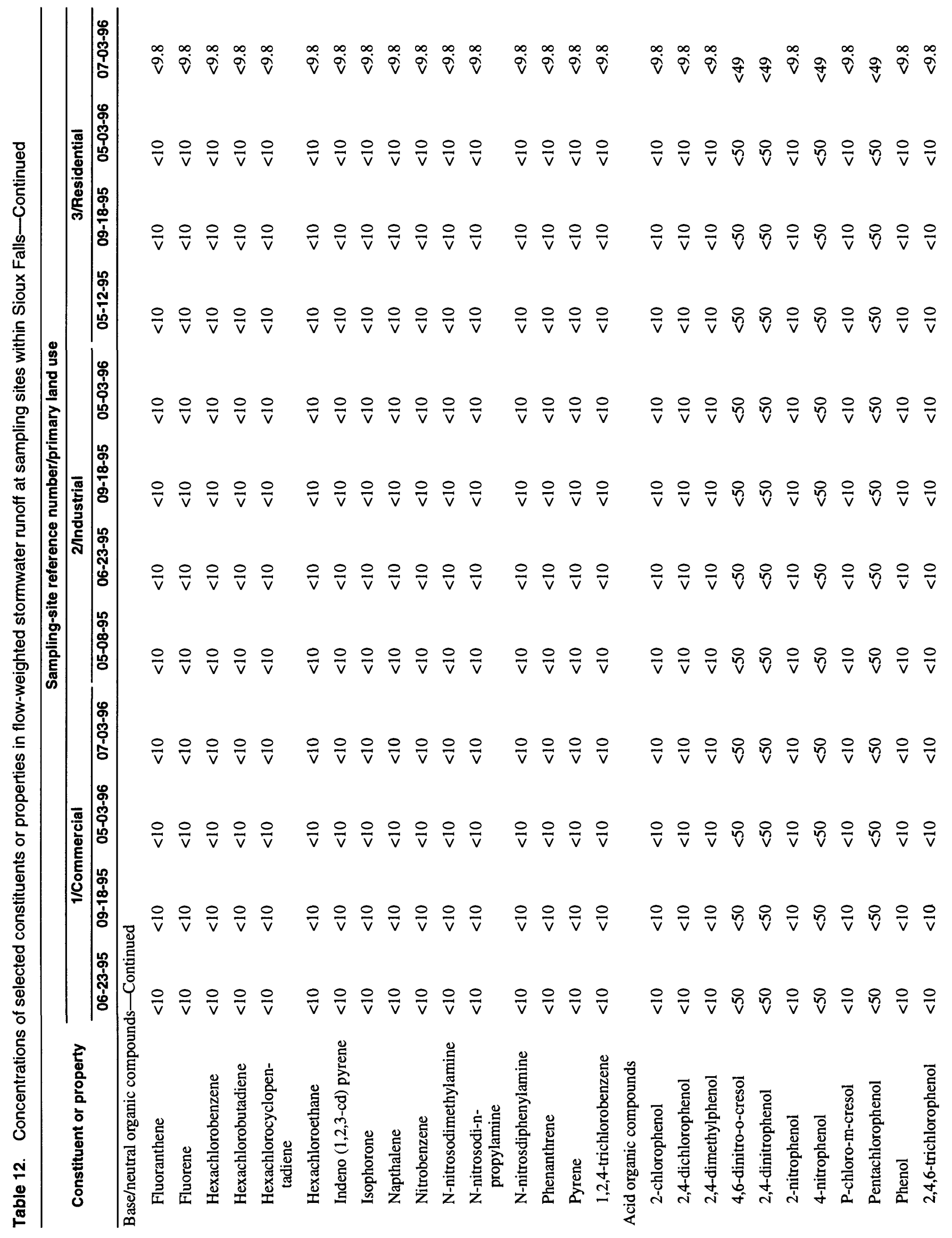




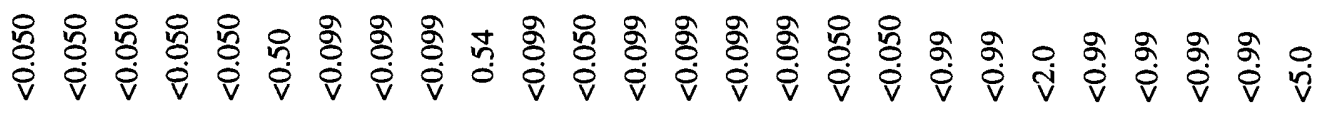

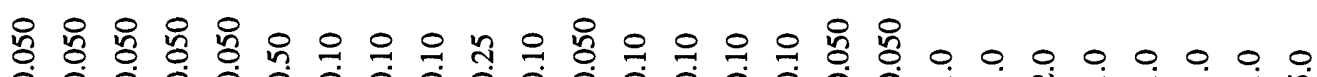

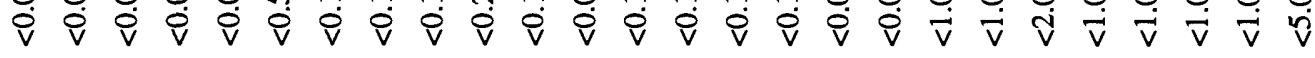

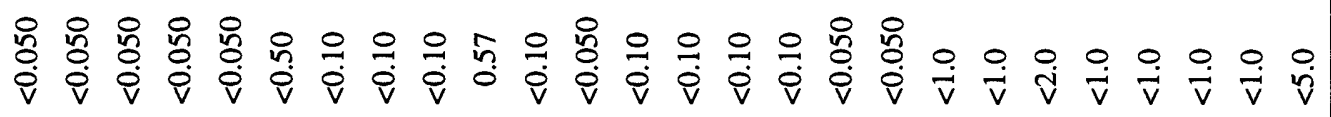

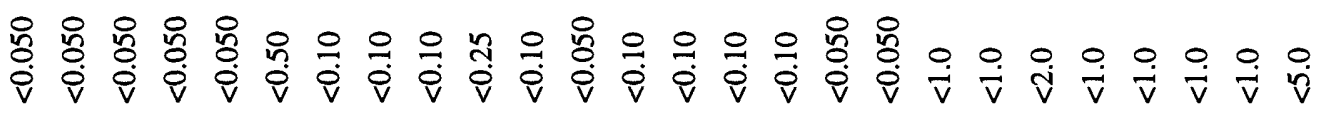

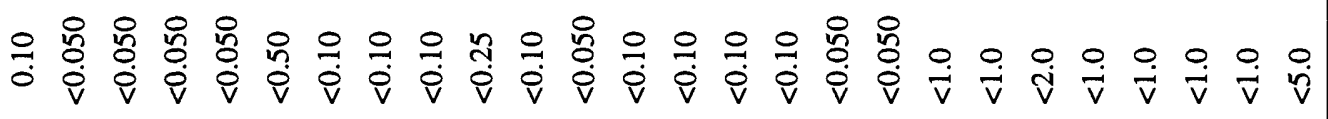

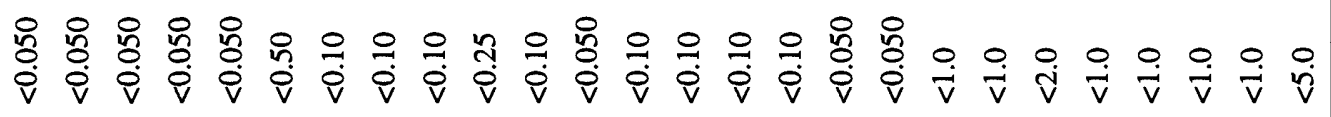

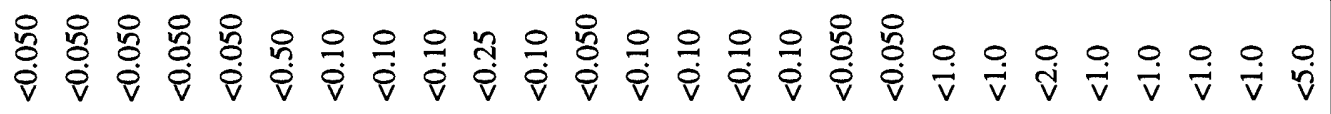

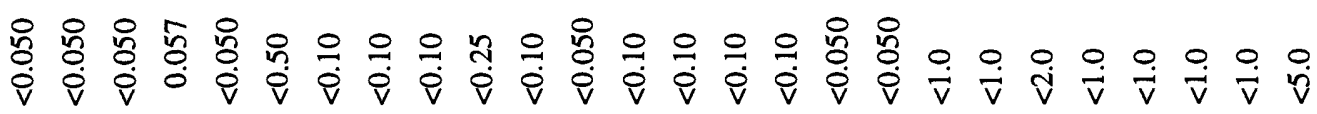

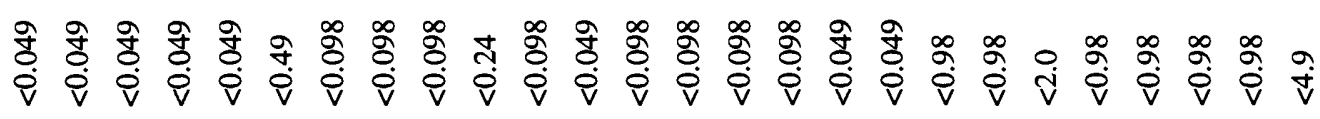

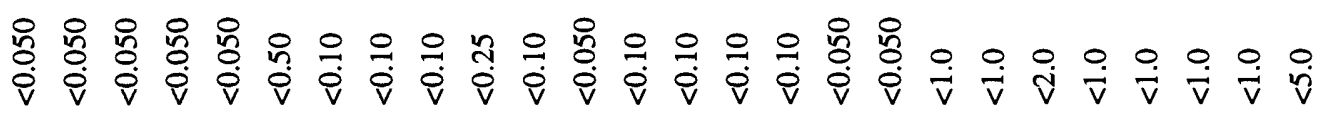

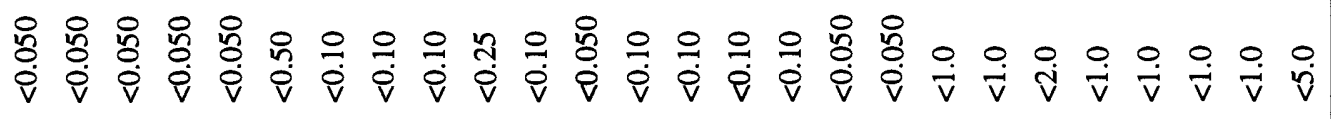

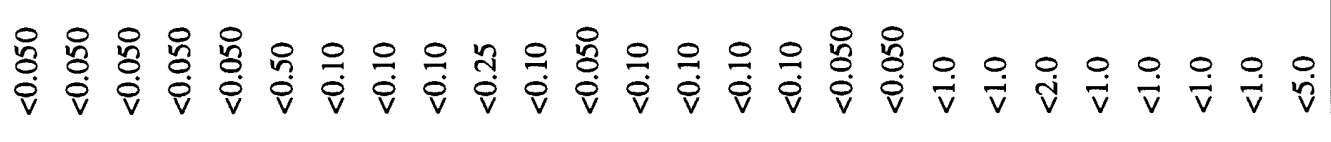
. 


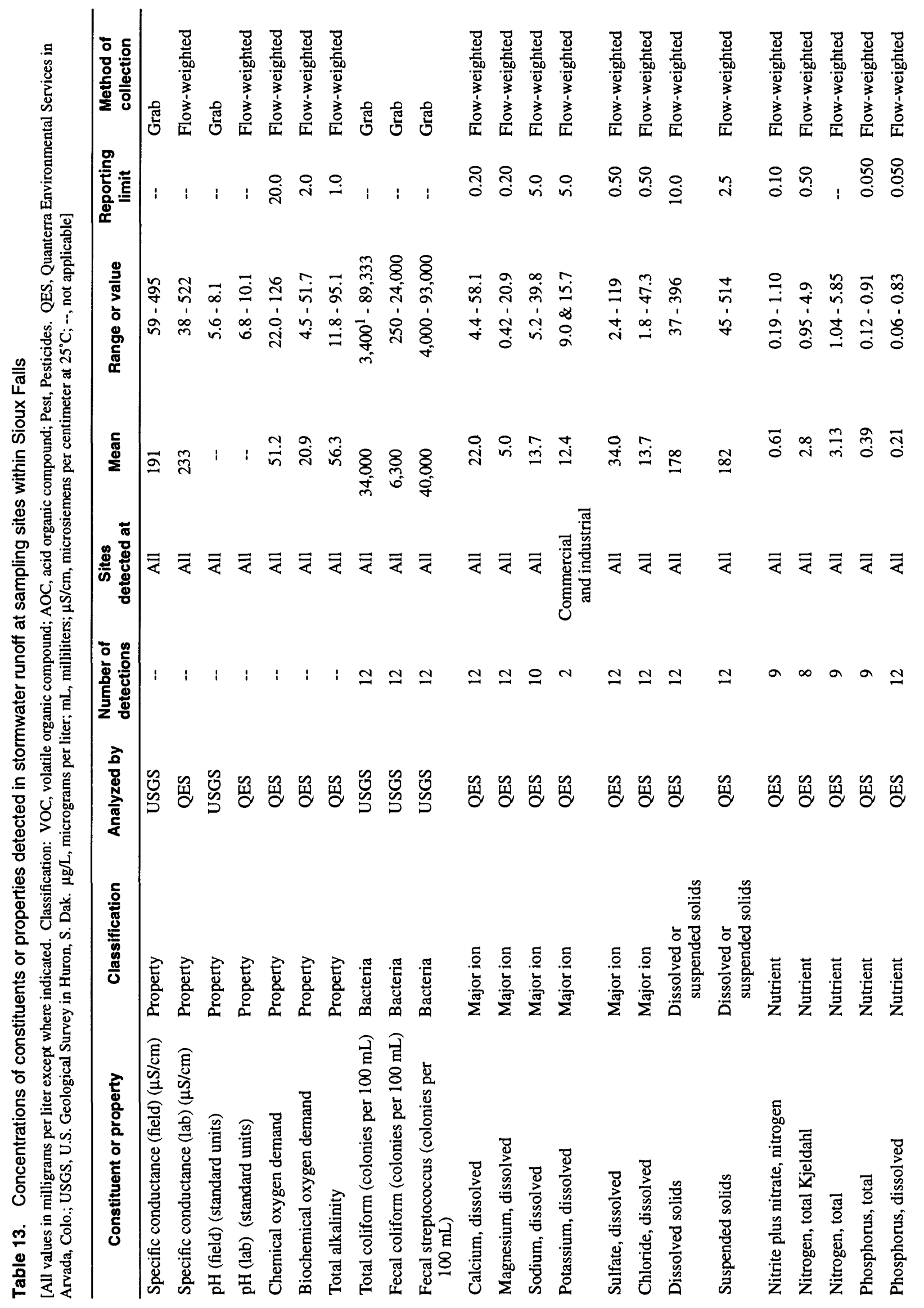




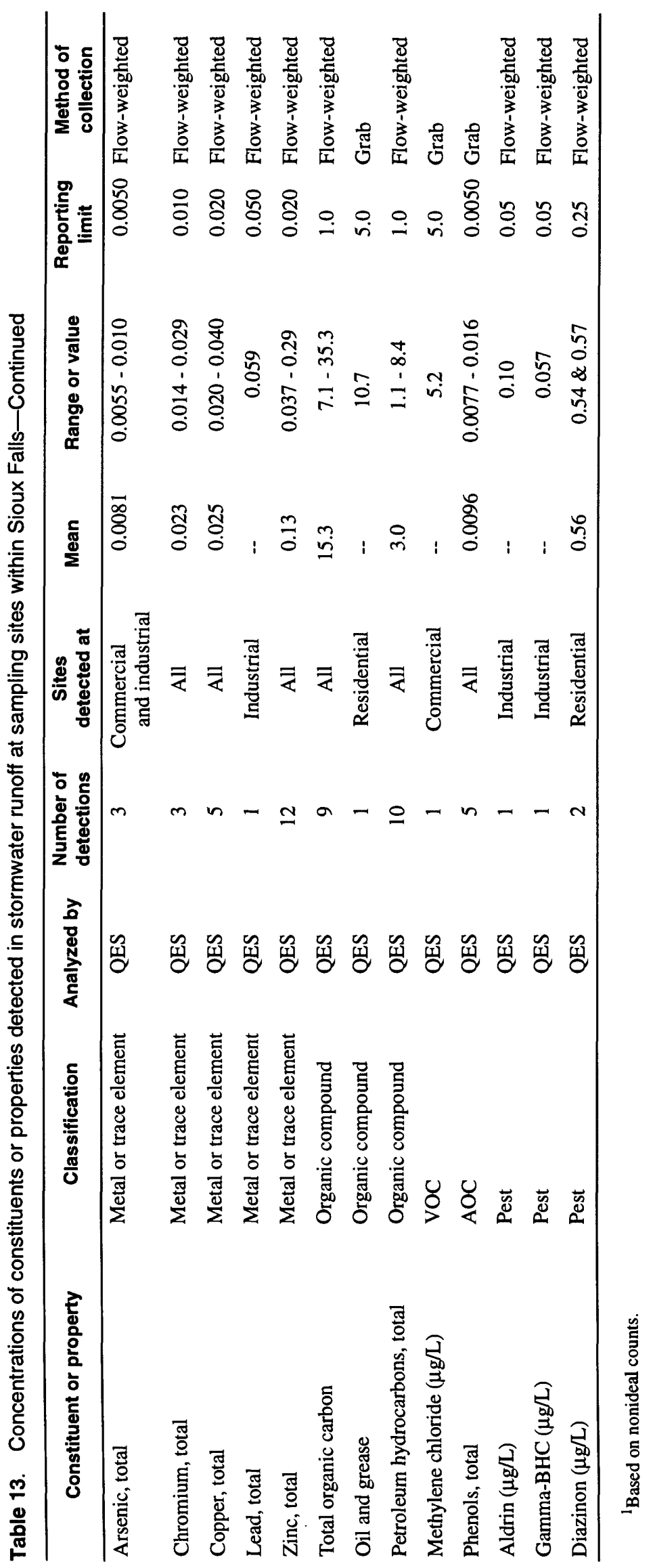


Estimated Annual Loads of Selected Constituents or Properties in Stormwater Runoff

It was assumed that the stormwater system serves all of the area within the City of Sioux Falls; therefore, load calculations are assumed to represent all stormwater runoff for Sioux Falls. Annual loads in stormwater runoff for Sioux Falls were estimated for chemical oxygen demand, biochemical oxygen demand, dissolved solids, suspended solids, total Kjeldahl nitrogen, total nitrogen, total phosphorus, dissolved phosphorus, total cadmium, total copper, total lead, and total zinc. Quantitative data for these 12 constituents or properties are re-tabulated in table 14.

Annual loads for all 12 constituents or properties were estimated using the national regression equations developed by the USGS (Driver and Tasker, 1990) and using the "simple method" in the Part 2 Guidance Manual (U.S. Environmental Protection Agency, 1992a) with the exception of biochemical oxygen demand, which was not calculated using the USGS national regression equation because there was no regression equation available. Both methods utilize information regarding precipitation, percentimperviousness or runoff-coefficient values, and drainage area. An analysis of precipitation records for Sioux Falls from 1949-88 showed the mean annual precipitation was 24.22 inches, the mean storm volume was 0.49 inch, and the average year had 43 storms (see table 1).

Percent-imperviousness and runoff-coefficient values are related to land use. Percent imperviousness is a variable in the national regression equations (Driver and Tasker, 1990), whereas runoff coefficient is a variable in the "simple method" from the Part 2 Guidance Manual (U.S. Environmental Protection Agency, 1992a). Percent imperviousness is used to calculate the runoff coefficient using equation 3 in the Part 2 Guidance Manual. A list of percent-imperviousness and runoff-coefficient values for each land-use type used in the load-estimate calculations is included in table 15. For the purposes of the load-estimate calculations, all areas not classified as commercial, industrial, or residential were considered to have the same percent imperviousness, 15 percent. Following is

Table 14. Concentrations of constituents or properties in stormwater runoff for which annual loads were calculated in Sioux Falls

[All values in milligrams per liter. Values reported by Quanterra Environmental Services laboratory in Arvada, Colo., unless otherwise noted by “*," then analyses done by U.S. Geological Survey in Huron, S. Dak.; <, less than; --, not applicable]

\begin{tabular}{|c|c|c|c|c|c|c|c|c|c|c|c|c|c|}
\hline $\begin{array}{c}\text { Site } \\
\text { number/ } \\
\text { land use }\end{array}$ & $\begin{array}{c}\text { Date } \\
\text { of } \\
\text { sample }\end{array}$ & $\begin{array}{l}\text { Chemi- } \\
\text { cal } \\
\text { oxygen } \\
\text { demand }\end{array}$ & $\begin{array}{l}\text { Bio- } \\
\text { chemi- } \\
\text { cal } \\
\text { oxygen } \\
\text { demand } \\
\text { 5-day }\end{array}$ & $\begin{array}{l}\text { Dis- } \\
\text { solved } \\
\text { solids }\end{array}$ & $\begin{array}{l}\text { Sus- } \\
\text { pended } \\
\text { solids }\end{array}$ & $\begin{array}{l}\text { Total } \\
\text { Kjeldahl } \\
\text { nitro- } \\
\text { gen }\end{array}$ & $\begin{array}{c}\text { Total } \\
\text { nitro- } \\
\text { gen }\end{array}$ & $\begin{array}{c}\text { Total } \\
\text { phos- } \\
\text { phorus }\end{array}$ & $\begin{array}{c}\text { Dis- } \\
\text { solved } \\
\text { phos- } \\
\text { phorus }\end{array}$ & $\begin{array}{l}\text { Total } \\
\text { cad- } \\
\text { mium }\end{array}$ & $\begin{array}{c}\text { Total } \\
\text { copper }\end{array}$ & $\begin{array}{l}\text { Total } \\
\text { lead }\end{array}$ & $\begin{array}{l}\text { Total } \\
\text { zinc }\end{array}$ \\
\hline \multirow{3}{*}{$\begin{array}{l}\text { 1/ } \\
\text { commercial }\end{array}$} & $06-23-95$ & -- & 51.2 & 396 & 60 & -- & -- & -- & 0.18 & $<0.0050$ & 0.020 & $<0.050$ & 0.17 \\
\hline & $05-03-96$ & 35.9 & $15.5^{*}$ & 179 & 347 & 2.2 & 2.46 & 0.30 & 0.06 & $<0.0050$ & 0.022 & $<0.050$ & 0.14 \\
\hline & $07-03-96$ & 126 & $27.9 *$ & 146 & 102 & 2.9 & 4.0 & 0.23 & 0.14 & $<0.0050$ & $<0.020$ & $<0.050$ & 0.13 \\
\hline \multirow{2}{*}{$\begin{array}{l}2 / \\
\text { industrial }\end{array}$} & $05-08-95$ & 25.1 & 4.5 & 137 & 142 & $<0.50$ & $<1.04$ & 0.38 & 0.12 & $<0.0050$ & $<0.020$ & $<0.050$ & 0.22 \\
\hline & $06-23-95$ & -- & 51.7 & 192 & 85 & -- & -- & -- & 0.83 & $<0.0050$ & 0.020 & $<0.050$ & 0.10 \\
\hline \multirow{4}{*}{$\begin{array}{l}3 / \\
\text { residential }\end{array}$} & $05-12-95$ & -- & -- & 287 & 50 & -- & -- & -- & 0.12 & $<0.0050$ & $<0.020$ & $<0.050$ & 0.037 \\
\hline & $09-18-95$ & 27.6 & 7.0 & 123 & 112 & 2.2 & 2.74 & 0.30 & 0.12 & $<0.0050$ & $<0.020$ & $<0.050$ & 0.050 \\
\hline & $05-03-96$ & 24.3 & $14.6^{*}$ & 119 & 514 & 3.4 & 3.59 & 0.47 & 0.097 & $<0.0050$ & 0.023 & $<0.050$ & 0.19 \\
\hline & $07-03-96$ & 115 & $17.7^{*}$ & 130 & 235 & 4.9 & 5.85 & 0.29 & 0.12 & $<0.0050$ & $<0.020$ & $<0.050$ & 0.069 \\
\hline
\end{tabular}


an example of how equation 3 in the Part 2 Guidance Manual was used to calculate the runoff coefficient for the residential land-use areas:

$$
\begin{gathered}
R v=(0.05+0.009 \times I A) \\
R v=(0.05+0.009 \times 24) \\
R v=0.27
\end{gathered}
$$

where

$$
\begin{aligned}
& R v=\text { runoff coefficient and } \\
& I A=\text { percent imperviousness. }
\end{aligned}
$$

Cumulative load estimates for Sioux Falls urban stormwater runoff are derived by calculating the load contributed by each land use and summing the results. The drainage area of each land use served by the stormwater system was determined using computerized coverages in the GIS. Areas for the six types of land use served by the stormwater system are shown in table 2 .
Table 15. Percent imperviousness and runoff coefficients of major land uses in Sioux Falls

[Runoff coefficient $=0.05+0.009 \times I A$, where $I A=$ percent imperviousness (U.S. Environmental Protection Agency, 1992a)]

\begin{tabular}{lcc}
\hline \multicolumn{1}{c}{ Land use } & $\begin{array}{c}\text { Percent } \\
\text { impervious- } \\
\text { ness }\end{array}$ & $\begin{array}{c}\text { Runoff } \\
\text { coefficient }\end{array}$ \\
\hline Commercial & 75 & 0.72 \\
Industrial & 55 & 0.54 \\
Residential & 24 & 0.27 \\
Agricultural and nonclassified & 15 & 0.18 \\
Parks and recreational & 15 & 0.18 \\
Planned residential or industrial & 15 & 0.18 \\
\hline
\end{tabular}

\section{National Regression Equation Method}

Driver and Tasker (1990) developed several different sets of national regression equations from extensive urban-stormwater runoff data (U.S. Environmental Protection Agency, 1983). For Sioux Falls, the three-variable storm-runoff-load models (table 16) were used to estimate the load for the average storm volume of 0.49 inch for each land use. The result was multiplied by 43 , the average number of storms in a year, to estimate the annual load from each land use in Sioux Falls.

Table 16. U.S. Geological Survey national regression equations for determining annual loads of selected constituents or properties

[SEE, standard error of estimate for the model; $R^{2}$, coefficient of multiple determination that measures the proportion of total variation about the mean load explained by regression; range of percent error, measure of the accuracy of the model based on the standard error of estimate. COD, annual chemical oxygen demand load, in pounds; $N S$, number of storms per year (average of 43 for 1949-88 period); $T R N$, total storm rainfall, in inches (average of 0.49 inch for 1949-88 period); $D A$, drainage area, in square miles (table 2); $I A$, impervious area, in percent (table 15); BOD, biochemical oxygen demand; USGS, U.S. Geological Survey; $D S$, annual dissolved solids load, in pounds; $S S$, annual suspended solids load, in pounds; $T K N$, annual total Kjeldahl nitrogen load, in pounds; $T N$, annual total nitrogen load, in pounds; $T P$, annual total phosphorus load, in pounds; $D P$, annual dissolved phosphorus load, in pounds; $C D$, annual total cadmium load, in pounds; $C U$, annual total copper load, in pounds; $P B$, annual total lead load, in pounds; $Z N$, annual total zinc load, in pounds. Models from Driver and Tasker (1990, p. 13)]

\begin{tabular}{lllc}
\hline \multicolumn{1}{c}{ Three-variable models for storm-runoff loads } & \multicolumn{1}{c}{$R^{2}$} & $\begin{array}{c}\text { SEE } \\
\text { (log) }\end{array}$ & $\begin{array}{c}\text { Range of } \\
\text { percent error }\end{array}$ \\
\hline$C O D=N S \times\left[151 \times T R N^{0.823} \times D A^{0.726} \times(I A+1)^{0.564} \times 1.451\right]$ & 0.67 & 0.376 & -58 to +138 \\
$B O D=$ USGS national regression equation not available & -- & -- & -- \\
$D S=N S \times\left[3.26 \times T R N^{1.251} \times D A^{1.218} \times(I A+1)^{1.964} \times 1.434\right]$ & 0.86 & 0.367 & -57 to +133 \\
$S S=N S \times\left[812 \times T R N^{1.236} \times D A^{0.436} \times(I A+1)^{0.202} \times 1.938\right]$ & 0.60 & 0.512 & -69 to +225 \\
$T K N=N S \times\left[3.89 \times T R N^{0.944} \times D A^{0.765} \times(I A+1)^{0.556} \times 1.524\right]$ & 0.75 & 0.381 & -58 to +140 \\
$T N=N S \times\left[4.04 \times T R N^{0.936} \times D A^{0.937} \times(I A+1)^{0.692} \times 1.373\right]$ & 0.77 & 0.353 & -56 to +125 \\
$T P=N S \times\left[0.697 \times T R N^{1.008} \times D A^{0.628} \times(I A+1)^{0.469} \times 1.790\right]$ & 0.62 & 0.411 & -61 to +158 \\
$D P=N S \times\left[0.060 \times T R N^{0.991} \times D A^{0.718} \times(I A+1)^{0.701} \times 1.757\right]$ & 0.63 & 0.412 & -61 to +158 \\
$C D=N S \times\left[0.021 \times T R N^{1.367} \times D A^{1.062} \times(I A+1)^{0.328} \times 1.469\right]$ & 0.62 & 0.386 & -59 to +143 \\
$C U=N S \times\left[0.013 \times T R N^{0.504} \times D A^{0.585} \times(I A+1)^{0.816} \times 1.548\right]$ & 0.55 & 0.417 & -62 to +161 \\
$P B=N S \times\left[0.150 \times T R N^{0.791} \times D A^{0.426} \times(I A+1)^{0.522} \times 1.665\right]$ & 0.43 & 0.442 & -64 to +177 \\
$Z N=N S \times\left[0.046 \times T R N^{0.880} \times D A^{0.808} \times(I A+1)^{1.108} \times 1.813\right]$ & 0.51 & 0.500 & -68 to +216 \\
\hline
\end{tabular}


Following is an example of how the regression equation for Region II (Driver and Tasker, 1990), which is used for areas having a total annual precipitation of 20 to 40 inches, was used to estimate the annual COD (chemical oxygen demand) load for all of the residential land use in Sioux Falls:

$$
\begin{gathered}
C O D=N S \times\left[151 \times T R N^{0.823} \times D A^{0.726} \times\right. \\
\left.(I A+1)^{0.564} \times 1.451\right] \\
C O D=43 \times\left[151 \times 0.49^{0.823} \times 21.15^{0.726} \times\right. \\
\left.(24+1)^{0.564} \times 1.451\right] \\
C O D=294,956 \mathrm{lbs}
\end{gathered}
$$

where

$$
\begin{aligned}
& C O D= \text { annual total chemical oxygen demand load, } \\
& \text { in pounds; } \\
& N S= \text { number of storms per year (average of } 43 \\
&\quad \text { from } 1949-88) ; \\
& T R N= \text { total storm rainfall, in inches (average of } \\
&0.49 \text { from } 1949-88) ; \\
& D A= \text { drainage area, in square miles }(21.15) ; \text { and } \\
& I A= \text { impervious area, in percent }(24) . \\
& \text { The standard error of the estimate }(S E E) \text { of the }
\end{aligned}
$$
mean is an estimate of the standard deviation about the regression. It is a measure of the relative accuracy of the regression model in predicting the response variable at sites where data have been collected. Based on the range of percent error in table 16, the load estimate for the COD regression model could range from $[294,956-(294,956 \times 0.58)]$ to $[294,956+(294,956 \times$ $1.38)$ ], or from 123,882 to 701,995 pounds per year.

The annual load estimates for a given constituent or property for each land use were summed to determine the estimated annual load in urban stormwater runoff for Sioux Falls. As an example, the estimated total annual COD load is 953,503 pounds, which is the sum of: 260,901 pounds (commercial) + 185,784 pounds (industrial) $+294,956$ pounds (residential) $+113,422$ pounds (agricultural and nonclassified) $+84,882$ pounds (parks and recreational) + 13,557 pounds (planned residential or industrial). The same procedure was used to calculate the annual load estimates for other constituents or properties using appropriate drainage area and imperviousness area (table 17).

\section{U.S. Environmental Protection Agency Simple Method}

Annual loads also were estimated using equation 1 of the "simple method" from the Part 2 Guidance Manual (U.S. Environmental Protection Agency, 1992a):

$$
L=\left[\frac{P \times C F \times R v}{12}\right] \times C \times A \times 2.72
$$

where

$L=$ annual constituent load, in pounds;

$P=$ annual precipitation, in inches per year (24.2);

$C F=$ correction factor that adjusts for storms where no runoff occurs (0.9);

$R v=$ runoff coefficient for the drainage area;

$C=$ event-mean concentration of constituent, in milligrams per liter; and

$A=$ drainage area, in acres.

The Part 2 Guidance Manual recommends 0.9 as the correction factor, which means that 90 percent of storms produce runoff. This factor was used in the load calculations for Sioux Falls urban stormwater runoff.

For each land use, three different site-specific event-mean concentration values were used to estimate the minimum, mean, and maximum annual load. Sample concentrations for a constituent or property from the three representative sampling sites were considered to be representative of all storm-related discharge from the corresponding land use. For example, sample concentration values from the industrial site were considered to be representative of runoff from all industrial land in Sioux Falls. All land not classified as commercial or industrial was treated as residential for load-calculation purposes. The minimum, mean, and maximum values of the storm events sampled at each site were used as the event-mean concentrations to estimate the minimum, mean, and maximum annual load, respectively, for the respective land use. If a concentration was reported as less than a value, it was set equal to that value for the load estimates. Following is an example of concentration values determined for copper at the industrial site:

\begin{tabular}{lcc}
$\begin{array}{c}\text { Site number/ } \\
\text { land use }\end{array}$ & Date & $\begin{array}{c}\text { Total copper } \\
\text { (mg/L) }\end{array}$ \\
\hline 2/industrial & $05-08-95$ & $<0.020$ \\
& $06-23-95$ & 0.020 \\
& $09-18-95$ & $<0.020$ \\
& $05-03-96$ & 0.040
\end{tabular}

Minimum event-mean concentration $=0.020 \mathrm{mg} / \mathrm{L}$ Maximum event-mean concentration $=0.040 \mathrm{mg} / \mathrm{L}$

Event-mean concentration $=(0.020 \mathrm{mg} / \mathrm{L}+0.020 \mathrm{mg} / \mathrm{L}+$ $0.020 \mathrm{mg} / \mathrm{L}+0.040 \mathrm{mg} / \mathrm{L}) / 4=0.025 \mathrm{mg} / \mathrm{L}$ 


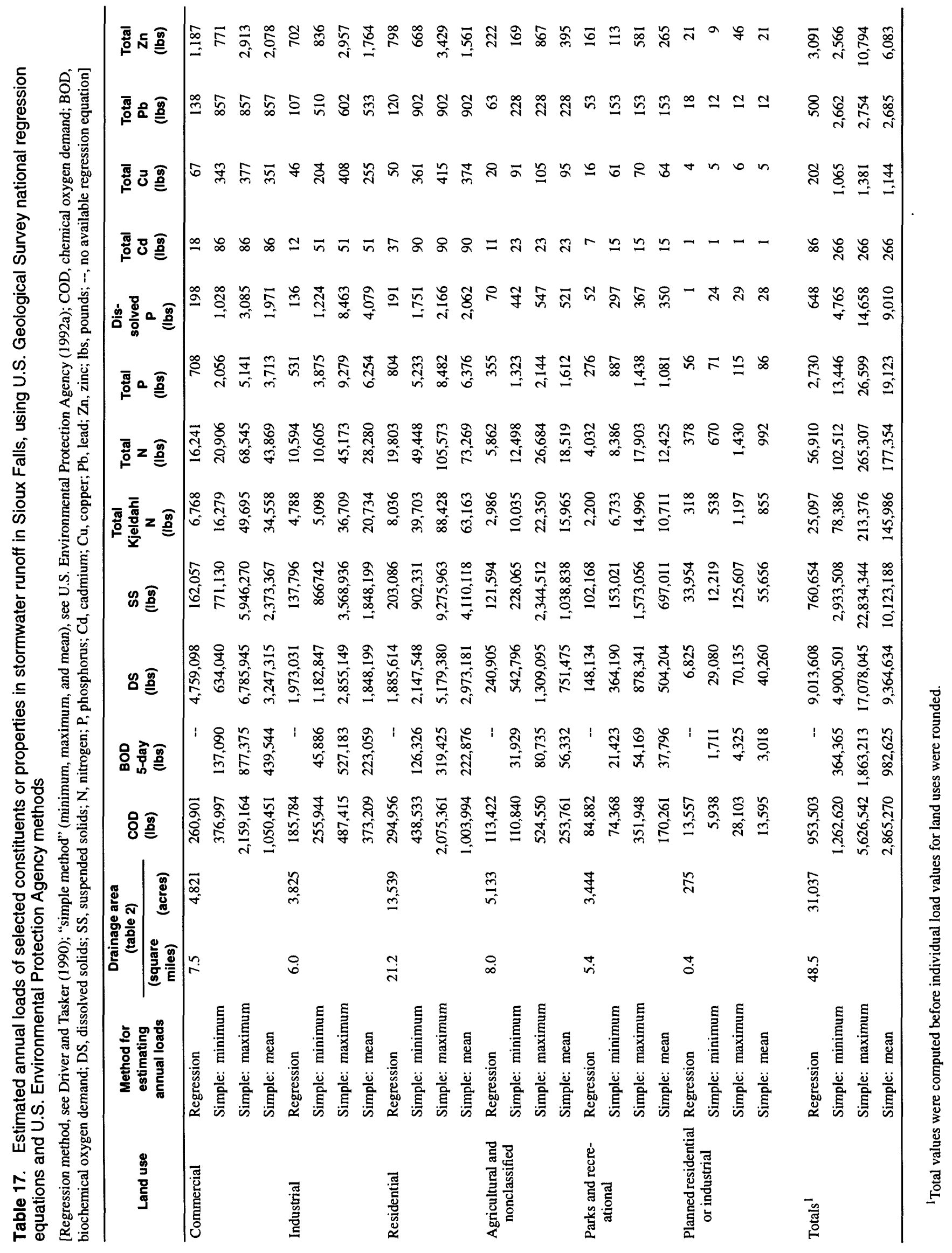


An example calculation using the "simple method" to estimate the mean annual copper load from industrial land in Sioux Falls (equation 1, Part 2 Guidance Manual, U.S. Environmental Protection Agency, 1992a) follows:

$$
\begin{aligned}
& L=\left[\frac{P \times C F \times R v}{12}\right] \times C \times A \times 2.72 \\
& L=\left[\frac{24.2 \times 0.9 \times(0.54)}{12}\right] \times 0.025 \times
\end{aligned}
$$

$$
3,825 \times 2.72=255 \mathrm{lbs} \text {. }
$$

The mean annual loads for a given constituent or property for each land use were summed to determine the mean annual load in all stormwater runoff in Sioux Falls. The mean annual copper load is 1,144 pounds, which is the sum of: 351 pounds (commercial) + 255 pounds (industrial) +374 pounds (residential) + 95 pounds (agricultural and nonclassified) +64 pounds (parks and recreational) +5 pounds (planned residential or industrial). The same procedure was used to calculate the minimum, maximum, and mean annual load estimates for other constituents or properties using respective concentration values (table 17).

The results of the annual load estimates for the 12 constituents or properties calculated by the national regression equation method and by the "simple method" are included in table 17. Loads for each major land-use type and total loads for the entire stormwater system are provided.

By applying the model error (see previous discussion on calculation of load range using regression model) to the results from the national regression equations (table 16) and comparing to the range of load estimates from the "simple method," the results for the total load calculation from the two methods are reasonably close for three constituents: dissolved solids, total cadmium, and total zinc. However, the "simple method" using the site-specific concentration data estimated larger loads for all 12 constituents or properties. The national regression equation results are much different than the "simple method" results for suspended solids, total Kjeldahl nitrogen, total phosphorus, and dissolved phosphorus. Possible explanations for the larger loads calculated using the "simple method" include site-specific differences between the local watershed and those sampled in the National Urban
Runoff Program (NURP) (U.S. Environmental Protection Agency, 1983); exclusion of runoff from industrial watersheds in the NURP study; setting the concentrations used in the "simple method" equal to the reporting limit, especially for cadmium, copper, and lead; and differences in sampling protocols. The entire storm hydrograph was sampled in the NURP, whereas only the first 3 hours of runoff was sampled for the NPDES permit procedure. The NURP study found that the majority of pollutants occur early in the runoff event, so larger calculated loads could be expected from the NPDES data for certain constituents or properties.

\section{Estimated Event-Mean Concentrations of Selected Constituents or Properties in Stormwater Runoff}

Event-mean concentrations of selected constituents or properties in stormwater runoff for Sioux Falls were calculated using estimated annual loads, annual rainfall, drainage areas, weighted-average runoff coefficients, and correction factors. The weighted-average runoff coefficient can be calculated using equation 2 of the Part 2 Guidance Manual (U.S. Environmental Protection Agency, 1992a), as demonstrated below:

$$
R v i=\text { Sum of } A i \times R v / \text { Sum of } A i
$$

$$
\begin{gathered}
R v i=[(4,821 \times 0.72)+(3,825 \times 0.54)+ \\
(13,539 \times 0.27)+(5,133 \times 0.18)+ \\
(3,444 \times 0.18)+(275 \times 0.18)] /(4,821+ \\
3,825+13,539+5,133+3,444+275) \\
R v i=10,785.5 / 31,037=0.3475
\end{gathered}
$$

where

$R v i=$ weighted-average runoff coefficient;

$A i=$ land-use area for specific land-use type (acres); and

$R v=$ runoff coefficient for specific land-use type.

Below is an example of how the cadmium maximum event-mean concentration for storm runoff was determined: 


$$
E M C=\frac{L}{(P \times C F \times R v i \times A \times(2.72 / 12))}
$$

$$
E M C=\frac{266}{(24.2 \times 0.9 \times 0.3475 \times 31,037 \times(2.72 / 12))}=
$$

$$
0.005 \mathrm{mg} / \mathrm{L}
$$

where

$$
\begin{aligned}
E M C= & \text { event-mean concentration of pollutant, in } \\
& \text { milligrams per liter; } \\
L= & \text { annual pollutant load, in pounds; } \\
P= & \text { annual precipitation, in inches per year } \\
& (24.2) ; \\
C F= & \text { correction factor that adjusts for storms } \\
& \text { where no runoff occurs }(0.9) ; \\
R v i= & \text { weighted-average runoff coefficient for the } \\
& \text { area served by the Sioux Falls stormwater } \\
& \text { system }(0.3475) ; \text { and } \\
\mathrm{A}= & \text { area served by the Sioux Falls stormwater } \\
& \text { system, in acres }(31,037) .
\end{aligned}
$$

The range of the estimated event-mean concentrations for the 12 constituents or properties for a typical runoff event in Sioux Falls are summarized in table 18.

\section{POSSIBLE EFFECTS OF STORMWATER RUNOFF}

Possible effects of Sioux Falls stormwater runoff on receiving water bodies were investigated. Quantity of runoff was estimated and compared to historical measured discharges in receiving waters. The effects of urbanization on water quality were evaluated using historical measurements of specific conductance in the Big Sioux River and Skunk Creek. Specifically, an attempt was made to determine if there is a measurable trend in specific conductance as the population of Sioux Falls has increased from 1973-95.

\section{Runoff Quantity}

Quantity of runoff from the area drained by the Sioux Falls stormwater system was estimated to show how it compares to the discharge in the Big Sioux River and Skunk Creek. The runoff volume was estimated by multiplying Sioux Falls' mean storm volume of 0.49 inch by the drainage area served by the Sioux Falls stormwater system $(31,037$ acres $)$. This total then was multiplied by the weighted-average runoff coefficient (0.3475), resulting in $19,200,000$ cubic feet of runoff. This amount of water represents the potential runoff from a single storm to the Big Sioux River, Skunk Creek, Covell Lake, unnamed depressions, and manmade holding ponds.

The average discharge from this runoff can be estimated by dividing the volume of $19,200,000$ cubic feet by the duration of the mean storm (11.1 hours), plus an estimated average time of travel to the receiving water bodies. The average time of travel was estimated as 6 hours based on observations during storm events at the three sampling sites. This estimation assumes that the average time it takes the first of the rainfall runoff to reach the receiving water bodies is the same as the average time it takes the last of the runoff to reach the receiving water bodies. This results in

\begin{tabular}{|c|c|c|c|c|c|c|c|c|c|c|c|c|}
\hline & $\begin{array}{c}\text { COD } \\
(\mathrm{mg} / \mathrm{L})\end{array}$ & $\begin{array}{c}\text { BOD } \\
\text { 5-day } \\
\text { (mg/L) }\end{array}$ & $\begin{array}{c}\text { DS } \\
\text { (mg/L) }\end{array}$ & $\begin{array}{c}\text { SS } \\
(\mathbf{m g} / \mathbf{L})\end{array}$ & $\begin{array}{c}\text { Total } \\
\text { Kjeldahl } \\
\mathbf{N} \\
\text { (mg/L) }\end{array}$ & $\begin{array}{c}\text { Total } \\
N \\
\text { (mg/L) }\end{array}$ & $\begin{array}{c}\text { Total } \\
\mathbf{P} \\
\text { (mg/l) }\end{array}$ & $\begin{array}{c}\text { Dis- } \\
\text { solved } \\
\text { P } \\
(\mathrm{mg} / \mathrm{L})\end{array}$ & $\begin{array}{c}\text { Total } \\
\text { Cd } \\
\text { (mg/ll) }\end{array}$ & $\begin{array}{c}\text { Total } \\
\text { Cu } \\
\text { (mg/L) }\end{array}$ & $\begin{array}{c}\text { Total } \\
\text { Pb } \\
\text { (mg/L) }\end{array}$ & $\begin{array}{c}\text { Total } \\
\text { Zn } \\
\text { (mg/L) }\end{array}$ \\
\hline Minimum & 23.7 & 6.8 & 92 & 55 & 1.47 & 1.93 & 0.25 & 0.089 & 0.005 & 0.020 & 0.050 & 0.048 \\
\hline Maximum & 105.7 & 35.0 & 321 & 429 & 4.01 & 4.98 & 0.50 & 0.275 & 0.005 & 0.026 & 0.052 & 0.203 \\
\hline Mean & 53.8 & 18.5 & 176 & 190 & 2.74 & 3.33 & 0.36 & 0.169 & 0.005 & 0.021 & 0.050 & 0.114 \\
\hline
\end{tabular}
about 310 cubic feet per second of urban stormwater runoff from Sioux Falls during an average storm event. The amount of this discharge to reach the Big Sioux River and Skunk Creek depends on how much of the runoff is held in unnamed depressions, manmade holding ponds (the City has about 20 stormwater detention ponds located throughout Sioux Falls), and Covell Lake. The amount of discharge that is contained in the unnamed depressions and manmade holding ponds during a representative storm event and associated

Table 18. Estimated event-mean concentrations of selected constituents or properties in stormwater runoff in Sioux Falls

[Annual loads and event-mean concentrations calculated using "simple method", see U.S. Environmental Protection Agency (1992a); COD, chemical oxygen demand; BOD, biochemical oxygen demand; DS, dissolved solids; SS, suspended solids; N, nitrogen; P, phosphorus; Cd, cadmium; Cu, copper; $\mathrm{Pb}$, lead; $\mathrm{Zn}$, zinc; lbs, pounds; $\mathrm{mg} / \mathrm{L}$, milligrams per liter] 
impacts on runoff water quality were not determined during this study. However, these unnamed depressions and manmade holding ponds certainly could improve the water quality of the urban runoff downstream of these depressions and ponds. The amount of improvement would depend on antecedent conditions prior to a storm event. These antecedent conditions for the manmade holding ponds could include the degree the accumulated sediment from past runoff has been removed from the ponds and the amount of water in the ponds. An analysis of the effectiveness of these holding ponds in improving water quality was not done for this study. The Covell Lake drainage area would produce about 15 cubic feet per second, and the Skunk Creek drainage area would produce about 50 cubic feet per second during an average storm event. If Covell Lake and Skunk Creek drainage areas are excluded, about 245 cubic feet per second of urban stormwater runoff from Sioux Falls is produced during an average storm event. In comparison, the annual mean discharge for the Big Sioux River at North Cliff Avenue, at Sioux Falls, streamflow-gaging station for 1972-95 is 650 cubic feet per second. During low flows in the Big Sioux River and in Skunk Creek, the runoff from an average storm event could represent a significant por- tion of these stream discharges, thereby affecting the water quality of Skunk Creek and the Big Sioux River within and downstream of Sioux Falls. However, the calculated 245 cubic feet per second of stormwater runoff certainly would be reduced by the unnamed depressions and manmade holding ponds.

\section{Runoff Quality}

\section{Big Sioux River}

The effects of urbanization on specific conductance of water of the Big Sioux River were investigated. Specific conductance was used because relatively long-term records exist, and because specific conductance is an approximate indication of the dissolved solids in water.

Records from the USGS streamflow-gaging station in Sioux Falls (Big Sioux River at North Cliff Avenue) for 1973-95 were used in the statistical analysis of trends. The data from analysis of water from the Big Sioux River were plotted to determine any trends in specific conductance between 1973 and 1995 (fig. 9). The population of Sioux Falls was 72,488 in 1970

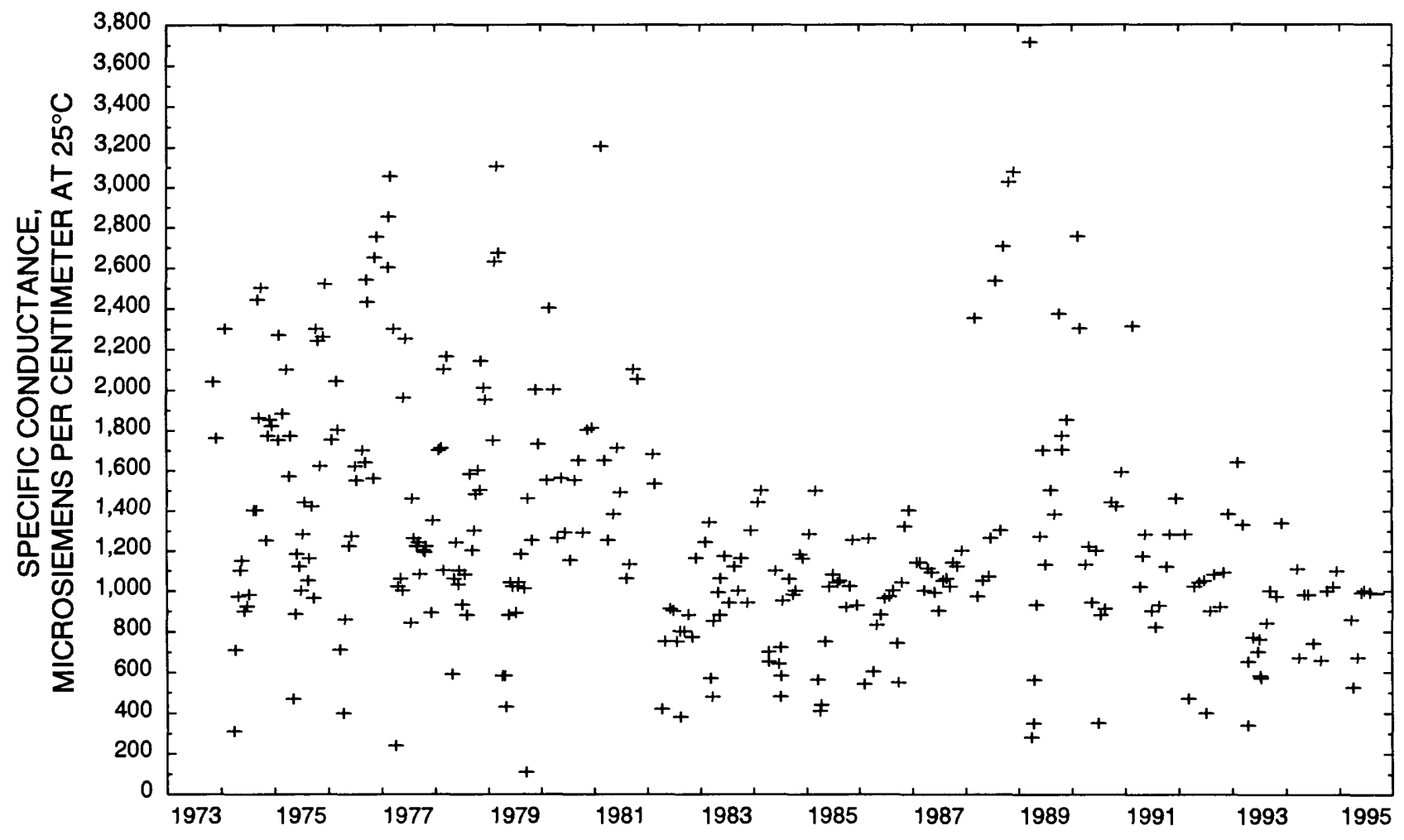

Figure 9. Measured specific conductances from 1973 to 1995 at USGS streamflow-gaging station 06482020, Big Sioux River at North Cliff Avenue, at Sioux Falls. 
(U.S. Census Bureau, oral commun., 1996), and 100,814 in 1990 (Sioux Falls Planning and Building Services Department, 1992). Examination of figure 9 indicates a possible negative trend in conductance (decreasing conductance through time). Regression of conductance versus time as the explanatory variable produced some indication of a negative conductance trend although $\mathrm{R}^{2}$ (represents that portion of the total variability of the specific conductance that is accounted for by the independent variable) was low. However, this result could be misleading because flow conditions and season of collection can affect the measured conductances. Statistical trend tests that take into account flow and seasonal effects were used to isolate these other factors.

Statistical trend tests that account for flow conditions at the time of collection of the samples were done first. These tests are limited by the fact that they do not account for seasonality effects on the conductance results. The Mann-Kendall trend test (Helsel and Hirsch, 1992) on residuals from regression of conductance versus flow and on residuals from LOWESS (Locally Weighted Scatterplot Smoothing) of conductance versus flow were used. LOWESS is a method for smoothing out variations in the data into a coherent pattern producing a trend line through the data (Helsel and Hirsch, 1992). Both tests adjust for flow, but the second test also is nonparametric (the data do not have to fit an assumed normal frequency distribution). The results of both of these trend tests did not indicate that a significant trend was present.

Statistical trend tests that account for both flow and seasonality effects were performed next. The seasonal Kendall trend test (Helsel and Hirsch, 1992) on residuals from regression of conductance versus flow and on residuals from LOWESS of conductance versus flow were used. Both tests adjust for flow and seasonality effects, but the second test also is nonparametric. The results of both of these trend tests did not indicate that a significant trend was present in specific conductance in the Big Sioux River. Apparently, flowadjusted specific conductances in the Big Sioux River at North Cliff Avenue have not significantly increased during 1973-95 when the population of Sioux Falls increased by more than 20,000 people.

A summary of the results of these statistical analyses are shown in table 19 . The p-value, or attained level of significance, represents the probability of observing a sample outcome more contradictory to the null hypothesis (that there is no trend) than the observed sample result. The smaller the p-value, the heavier the weight of the sample evidence for rejecting the null hypothesis and accepting that there is a trend (Helsel and Hirsch, 1992; Ott, 1988).

Tau is a correlation coefficient that measures the strength of the monotonic relationship between two sample groups. Tau is a rank-based coefficient and therefore nonparametric (resistant to the sample set not being normally distributed) (Helsel and Hirsch, 1992).

Because only a very small portion of the total

Big Sioux River drainage lies within Sioux Falls, it is unlikely that stormwater runoff from Sioux Falls is the only contributor to any trend in specific conductance (an indicator of dissolved-solids concentrations) in the Big Sioux River. Other possible contributors to any dissolved-solids trend include changes in agricultural practices and other land-use factors in the Big Sioux River Basin upstream from Sioux Falls.

Table 19. Summary of trend tests on specific conductance for water from the U.S. Geological Survey streamflow-gaging stations in Sioux Falls on the Big Sioux River (North Cliff Avenue, at Sioux Falls) and Skunk Creek (Skunk Creek at Sioux Falls)

$\left[Y=\right.$ the random response variable (specific conductance); $T=$ time; $X=$ an exogenous variable (flow) expected to affect the value of $Y ; R^{2}=$ coefficient of determination or fraction of the variance explained by regression; $p$-value $=$ the probability of obtaining the test statistic, or one even less likely, when the null hypothesis is true; tau = measure of the strength of the monotonic relationship between two sample groups; ---, not applicable; >=, greater than or equal to]

\begin{tabular}{|c|c|c|c|c|c|c|}
\hline \multirow{2}{*}{ Trend Test ${ }^{1}$} & \multicolumn{3}{|c|}{ Big Sioux River } & \multicolumn{3}{|c|}{ Skunk Creek } \\
\hline & $\mathbf{R}^{2}$ & p-value & tau & $\mathbf{R}^{2}$ & p-value & tau \\
\hline Regression of $\mathrm{Y}$ on $\mathrm{T}$ & 0.08 & 0.00 & -- & 0.01 & $>=0.13$ & -- \\
\hline Mann-Kendall on residuals from LOWESS of $\mathrm{Y}$ on $\mathrm{X}$ & -- & 0.40 & 0.03 & -- & 0.01 & 0.12 \\
\hline Seasonal Kendall on residuals from regression of $\mathrm{Y}$ on $\mathrm{X}$ & -- & 0.01 & -0.13 & - & 0.00 & 0.17 \\
\hline
\end{tabular}

${ }^{1}$ From Helsel and Hirsch (1992). 


\section{Skunk Creek}

The effects of urbanization on specific conductance from water in Skunk Creek also were investigated using similar methods that were used on the Big Sioux River. Records from the USGS streamflowgaging station in Sioux Falls (Skunk Creek at Sioux Falls) for 1973-95 were used in the statistical analysis of trends.

The data from analysis of water from Skunk Creek were plotted to show if any trends in conductance could be apparent from 1973-95 (fig. 10). No trend in conductance was apparent. Statistical analyses using regression of conductance versus time as the explanatory variable also did not indicate that a significant trend was present.

Again, flow conditions and season of collection could affect the measured conductances. Statistical trend tests that account for flow conditions at the time of collection of the samples were again done first. Both the Mann-Kendall trend test on residuals from regression of conductance versus flow and on residuals from LOWESS of conductance versus flow indicated a significant positive trend.
Statistical trend tests that account for flow and seasonality effects were then done. The seasonal Kendall trend test on residuals from regression of conductance versus flow and on residuals from LOWESS of conductance versus flow indicated a significant positive trend (increasing specific conductance with increasing time). A summary of the results of these statistical analyses are shown in table 19.

Apparently, flow-adjusted concentrations of dissolved solids in Skunk Creek at Sioux Falls have increased during 1973-95, a period which also had an increase in the population of Sioux Falls. However, because only a very small portion of the total Skunk Creek drainage lies within Sioux Falls, it again is unlikely that stormwater runoff from Sioux Falls is the only contributor to the positive trend in flow-adjusted specific conductance (an indicator of dissolved-solids concentrations) in Skunk Creek. Other possible contributors to the positive dissolved-solids trend include changes in agricultural practices and other land-use factors in the Skunk Creek basin upstream from Sioux Falls.

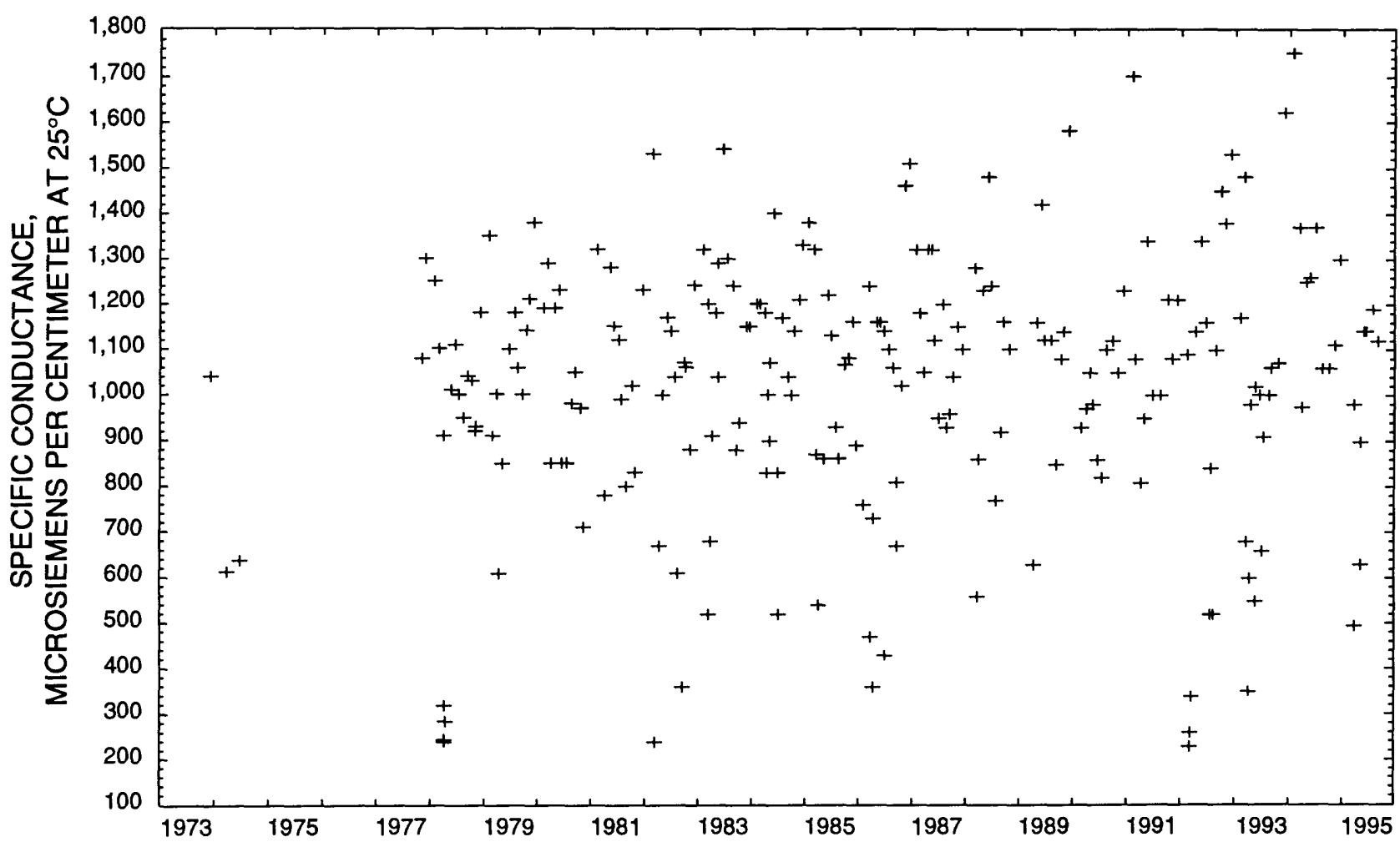

Figure 10. Measured specific conductances from 1973 to 1995 at USGS streamflow-gaging station 06481500 , Skunk Creek at Sioux Falls. 


\section{SUMMARY}

The USGS cooperated with the City of Sioux Falls during 1993-97 to characterize urban stormwater runoff and to determine the effects of the stormwater runoff on receiving waters in Sioux Falls, South Dakota. The study included collecting stormwater runoff at three sites considered representative of commercial, industrial, and residential land uses and analyzing for selected constituents or properties; estimating annual loads and event-mean concentrations of selected constituents or properties in stormwater runoff; evaluating the effects of the quantity of stormwater runoff on receiving waters; and analyzing trends in specific conductance of receiving waters.

Stormwater-runoff samples were collected during 1995 and 1996 at three sites that were considered representative of the major land uses (commercial, industrial, and residential) in Sioux Falls. The first sampling site was considered representative of commercial land use, drained 0.23 square mile, and was located at the southwest edge of Sioux Falls in an open channel upstream of two 72-inch culverts that drain into the Big Sioux River. The second sampling site was considered representative of industrial land use, drained 1.09 square miles, and was located at the northcentral edge of Sioux Falls in an open channel upstream of two 48-inch culverts that drain into the Big Sioux River Diversion Channel. The third sampling site was considered representative of residential land use, drained 0.51 square mile, and was located in the southwest part of Sioux Falls in a concrete-lined open channel upstream of three 54-inch culverts that drain into Skunk Creek.

At each sampling site, stage, discharge, rainfall, and water-quality samples were measured and/or collected during representative storms occurring at least one month apart. Four sets of stormwater samples were collected at each sampling site during six representative storm events. The runoff was sampled at the commercial, industrial, and residential sites from storms that had total rainfall that ranged from 0.16 to 0.75 inch. The elapsed dry period (period preceding sampling where there were no storms of greater than 0.10 inch) ranged from 72 to 317 hours at the three sites.

The collected samples were analyzed for nearly 150 constituents or properties including chemical and biochemical oxygen demands, bacteria, major ions, dissolved and suspended solids, nutrients, metals and trace elements, cyanide, and organics (volatile, base/ neutral, acid, and pesticide compounds). Constituents including bacteria, cyanide, oil and grease, volatile organic compounds, and total phenols were collected as grab samples. The grab samples typically were collected manually in the middle of open channels within 1 hour after runoff commenced from acceptable storms. Field measurements of specific conductance, $\mathrm{pH}$, water temperature, and total residual chlorine were made at approximately the same time that the grab samples were collected. Discrete samples intended for later flow-weighted compositing typically were collected using automatic samplers for the first hour of the storm. Additional discrete samples were collected manually every 15 minutes for the remainder of the stormwater runoff period or for a maximum of two additional hours. The discrete samples were later composited in direct proportion to the discharge occurring at the respective times of collection. Total sampling time was a maximum of 3 hours from the start of runoff or until the storm ended and the stage in the channel returned to its pre-storm level.

Annual loads and event-mean concentrations in stormwater runoff for Sioux Falls were estimated for chemical oxygen demand, biochemical oxygen demand, dissolved solids, suspended solids, total Kjeldahl nitrogen, total nitrogen, total phosphorus, dissolved phosphorus, total cadmium, total copper, total lead, and total zinc. Annual loads were estimated using the national regression equations developed by the USGS and using the "simple method" recommended by the U.S. Environmental Protection Agency. Load calculations by the "simple method" generally were larger than those determined using national regression equations. Event-mean concentrations were calculated using estimated annual loads, annual rainfall, drainage areas, weighted-average runoff coefficients, and correction factors.

Possible effects of the quantity of Sioux Falls stormwater runoff on receiving water bodies were investigated. The volume and discharge of stormwater runoff to receiving waters were estimated to show how it compares to the discharge in the Big Sioux River and Skunk Creek. The runoff volume from a mean storm of 0.49 inch was estimated at $19,200,000$ cubic feet. This amount of water represents the potential runoff from a single storm to the Big Sioux River, Skunk Creek, Covell Lake, unnamed depressions, and manmade holding ponds within Sioux Falls. The average discharge from urban stormwater runoff in Sioux Falls was estimated at about 310 cubic feet per second 
during an average storm event. The amount of this discharge to reach the Big Sioux River and Skunk Creek depends on how much of the runoff is held in unnamed depressions, manmade holding ponds, and Covell Lake. In comparison, the annual mean discharge for the Big Sioux River at North Cliff Avenue, at Sioux Falls, streamflow-gaging station for 1972-95 is 650 cubic feet per second. During low flows in the Big Sioux River and Skunk Creek, the runoff from an average storm event could represent a significant portion of these stream discharges, thereby affecting the water quality of Skunk Creek and the Big Sioux River within and downstream of Sioux Falls.

The effects of urbanization on water quality were evaluated using historical measurements of specific conductance in the Big Sioux River and Skunk Creek. Specifically, trends in specific conductance from receiving waters (Big Sioux River and Skunk Creek) were analyzed to study any changes in water quality of the receiving waters in Sioux Falls. Specific conductance of water from the USGS streamflow-gaging station on the Big Sioux River at North Cliff Avenue, at Sioux Falls was plotted to show if any trends in conductance could be seen between 1973 and 1995 . Examination of a plot of specific conductance versus time for this station indicates a possible negative trend in conductance. Regression of conductance versus time as the explanatory variable supports this observation. However, this result could be misleading because flow conditions and season of collection can affect the measured conductances. Statistical-trend tests that take into account the flow and seasonal effects did not indicate that a significant trend was present in specific conductance in the Big Sioux River.

The effects of urbanization on specific conductance from water from Skunk Creek at the USGS streamflow-gaging station on Skunk Creek at Sioux Falls also were investigated using similar methods that were used on the Big Sioux River. Examination of a plot of specific conductance versus time for this station and regression of conductance versus time did not indicate that a significant trend was present. However, this observation and regression again could be misleading because the flow conditions and season of collection could affect the measured conductances. Statisticaltrend tests that take into account flow and seasonal effects indicated a significant positive trend.

\section{SELECTED REFERENCES}

DeWild, Grant, Reckert, and Associates Company, 1979, West Mesa Highlands Drainage Study, Sioux Falls, South Dakota: variously paged.

1986, Pebble Creek Drainage Study, Sioux Falls, South Dakota: variously paged.

1987, Prairie View Watershed Drainage Study, Sioux Falls, South Dakota: variously paged.

1990, Northeast Area Drainage Study, Sioux Falls, South Dakota: variously paged.

1992a, 13th/Kiwanis Drainage Study, Sioux Falls, South Dakota: variously paged.

1992b, Sycamore East/Capitol Hills Drainage Study, Sioux Falls, South Dakota: variously paged.

Driver, N.E., and Tasker, G.D., 1990, Techniques for estimation of storm-runoff loads, volumes, and selected constituent concentrations in urban watersheds in the United States: U.S. Geological Survey Water-Supply Paper 2363, $44 \mathrm{p}$.

Fishman, M.J., and Friedman, L.C., eds., 1989, Methods for determination of inorganic substances in water and fluvial sediments: U.S. Geological Survey Techniques of Water-Resources Investigations, book 5, chap. A1, $545 \mathrm{p}$.

HDR Engineering, Inc., 1993, Covell Lake Drainage Basin Water Quality: $22 \mathrm{p}$.

1994, Southwest Area Drainage Analysis, Sioux Falls, South Dakota: variously paged.

Helsel, D.R., and Hirsch, R.M., 1992, Statistical methods in water resources: Studies in Environmental Science 49, New York, Elsevier Science, 522 p.

JSA Engineers and Land Surveyors, Inc., 1989, Drainage study for the watershed area east of the Big Sioux River between 18th Street and 26th Street, Sioux Falls, South Dakota: variously paged.

1990a, Drainage study for Lyndale Watershed Basin, Sioux Falls, South Dakota: variously paged. 1990b, Drainage study for Ebenezer Watershed Basin, Sioux Falls, South Dakota: variously paged. 1993, Engineering report for 26th and Sycamore Avenue Drainage Basin, Sioux Falls, South Dakota: variously paged.

1994, Engineering report for Morrell's Drainage Basin, Sioux Falls, South Dakota: variously paged. 1995, Engineering report for 41st Street Drainage Basin, Sioux Falls, South Dakota: variously paged.

Lindgren, R.J., and Niehus, C.A., 1992, Water resources of Minnehaha County, South Dakota: U.S. Geological Survey Water-Resources Investigations Report 91$4101,80 \mathrm{p}$.

National Oceanic and Atmospheric Administration, 194988, Climatological data, South Dakota: National Weather Service monthly summaries (1949-88): variously paged. 
Ott, Lyman, 1988, An introduction to statistical methods and data analysis: Boston, PWS-Kent Publishing Co., $835 \mathrm{p}$.

R.F. Sayre and Associates, 1986, Kennedy and Charlotte Avenues Drainage Study, Sioux Falls, South Dakota: variously paged.

1991, Hills of Rest Drainage Study, Sioux Falls, South Dakota: variously paged.

Schaap, B.D., and Lucey, K.J., 1994, Selected nutrients in stormwater runoff from Davenport, Iowa, 1992: U.S. Geological Survey Water-Resources Investigations Report 94-4130, 29 p.

Sioux Falls Planning and Building Services Department, 1992, Sioux Falls by Census Tract: $6 \mathrm{p}$. 1993, Comprehensive Development Plan, City of Sioux Falls, South Dakota: 7 p.

South Dakota Department of Environment and Natural Resources, 1992, 305(b) water quality assessment: 229 p.

1993, 1993 South Dakota Nonpoint Source Program Annual Report: 112 p.
U.S. Environmental Protection Agency, 1983, Final report of the nationwide urban runoff program: Washington, D.C., Water Planning Division, Office of Water: variously paged.

1990, National Pollutant Discharge Elimination permit application regulations for stormwater discharges: U.S. Federal Register, v. 55, no. 222, p. 47990-48091. 1991, Guidance manual for the preparation of part 1 of the NPDES permit applications for discharges from municipal separate storm sewer systems: EPA-505/891-003A: $176 \mathrm{p}$.

1992a, Guidance manual for the preparation of part 2 of the NPDES permit applications for discharges from municipal separate storm sewer systems: EPA-833/B92-002, $152 \mathrm{p}$.

1992b, NPDES stormwater sampling guidance document: EPA 833/B--92-001, 182 p.

U.S. Geological Survey, 1974-96, Water resources data for South Dakota, 1973-95: U.S. Geological Survey Water-Data Reports SD-73-1 to SD-95-1 (published annually). 
SUPPLEMENTAL INFORMATION

pope 65 frolions 


\section{SIOUX FALLS URBAN RUNOFF FIELD SAMPLING PROTOCOL}

\section{April 30, 1995}

\section{PRESAMPLING PREPARATION}

A. Supplies and equipment checklist

Location of items in Huron:

1. protocols

2. rating tables for each site

3. labeled Quanterra, field, and Huron sampling bottles for laboratory analyses

4. four large and one small round coolers (use one for ice)

5. one 5-gallon bottle of DI water

6. one small bottle of non-phosphate detergent

7. one 5-gallon bottle of tap water

8. one 1-gallon bottle of methanol

9. one large wash basin

10. sample bottle labels for discrete samples, Quanterra samples, and other samples

11. 1 peristaltic pump, Teflon tubing, 2 filter units, 0.45 micro membrane filters, and batteries

12. ascorbic acid with measuring spoons

13. one bottle of $10 \%$ sodium thiosulfate with dropper

14. one HACH kit for residual chlorine

15. one field laptop computer with SWD1 program loaded

16. chain-of-custody forms

17. disposal safety gloves and goggles

18. aluminum foil roll

19. flashlights and one spotlight

20. one calculator

21. plastic bags

22. one cellular phone (for communication between teams)

23. life preservers

24. set of conductance standards $(100,250,500$, and 1,000)

25. set of $\mathrm{pH}$ standards $(4,7$, and 10$)$

26. $\mathrm{pH}$ meters and DI water bottles

27. conductance meters

28. thermometers

29. two incubators

30. copy of "Guidelines for the Collection of Water-quality Samples in S.D. District"

31. three $500 \mathrm{~mL}$ sterilized glass bottles for bacteria sample

32. decontamination documentation forms

33. rain gear

34. waders or hip boots

\section{LOCATION OF ADDITIONAL ITEMS NEEDED FOR LABORATORY:}

1. ten 1-gallon glass bottles

2. cone splitter

3. magnetic stir bar unit with teflon stir bars and one teflon stir rod

4. bottles of nonphosphate detergent

5. aluminum foil

6. 1-gallon bottles of methanol

7. sample bottle labels

8. glass funnels 
9. various graduated glass cylinders $(500 \mathrm{~mL}$ and 1 liter $)$

10. plastic bags (for shipment of samples)

11. protocols

12. supplies for bacteria analyses (petri dishes, phosphate buffer, bacteria filtering unit with 0.7 \& 0.45 filters, 2 bact-T (media) kits, $10 \mathrm{~mL}$ pipets)

13. one-piece 0.45 filters for Quanterra samples

14. kim wipes

15. hot plate for bacteria agar preparation

16. MSDS sheets for all chemicals

\section{LOCATION OF NEEDED ITEMS AT SIOUX FALLS SAMPLING SITES:}

1. fifteen 1-gallon glass bottles with teflon interior lids

B. Decontamination of sampling bottles and equipment done before storm event (wear latex gloves)

1. wash with non-phosphate detergent and water

2. rinse several times with tap water

3. rinse with deionized water

4. rinse with methanol

5. rinse with deionized water

6. cap bottles and lids with aluminum foil

7. air dry

8. document cleaning

\section{MOBILIZATION FOR IMMINENT STORM EVENT}

A. Weather monitoring and initial mobilization

1. Check forecast and radar frequently for timing and potential storm events. Use mosaic on Data General computers to check forecasts and radars. Call Sioux Falls NWS for forecasts. (Representative storm is from 0.25 to 0.75 inches of rain in a period of 5.5 to 16.6 hours.) (This is only a goal-some leeway is available on the actual storm sampled, especially when it comes to duration).

2. Monitor site using laptop computer to see what is occurring at site (precipitation, stage, battery voltage, etc). Check SWD1 program to see if functional.

3. If it is determined that a representative storm is a good possibility in Sioux Falls, the teams are notified and meet at the Huron garage to load equipment and ice for coolers. (There will be three teams of two people (one team for each site). A stream gager must be a team member at each site.)

4. Each site will be sampled three different times at least one month apart. A representative storm must be preceded by at least 72 hours of dry weather. The entire storm runoff, up to a maximum of 3 hours, will be sampled.

5. The SWD1 and ISCO samplers will always be left on. The SWD1 and ISCO samplers will already be programmed (see a-d below for settings). The triggering gage height and precipitation will be set at a high value to keep the sites always on pre-event. Before leaving for Sioux Falls, the laptop computer will be used to activate the SWD1 and ISCO samplers.

a. The settings (set at 999 until ready to let storm trigger) will be modified to allow sampling to occur as follows:

resid $1 \mathrm{~m}$. dld: stage trigger 0.45 no flow $=0.45,0.04=$ offset

indus $1 \mathrm{~m} . d \mathrm{~d}$ : stage trigger 0.45 no flow $=0.45,0=$ offset

$\&$ com1m.dld: stage trigger 0.60 no flow $=0.59 .0 .20=$ offset

$* * *$ check site on monitor first, and if decision is made to sample and stage is already

higher than trigger even though hasn't rained, you will need to set stage trigger a little higher before download (then new rain will trigger sampler, not existing flow) 
b. Need to set flag1 "high" (which resets flag 6 high, which sets the sampler in a prevent situation) a few minutes after download data to SWD1 system; then wait until stabilizes and flag 6 is automatically high (may have to reset flag 1 high to do)

c. This will cause the ISCO to take a dummy sample in bot\#1 and then wait for stage trigger, then sample \#1 in bot\#2 $15 \mathrm{~min}$. after stage trigger, etc.

d. The ISCO will be set to take a sample every 15 minutes (time weighted).

6. Each team proceeds to preassigned sites. Must arrive at sites within 1 hour of onset of runoff event (preferably before runoff commences). The three sites are located as follows:

a. residential: along 26th street between intersections of 26th and Marion Rd. and 26th and Berkshire; get to site via I29, then west on 12th Street, then south on Marion Rd., then west on 26th.

b. commercial: along Louise Ave. east of Wal-Mart and Sam Club areas; just south of Charter Hospital; get to site via I29, then east on 41st Street, then north on Louise Ave., then south of Charter Hospital.

c. industrial: east of intersection of Benson Rd. and Minn. Ave. across Big Sioux River Diversion Channel; get to site via I29, then east on Hwy. 28A, then south on Minn. Ave., then east on Benson Rd.

\section{ARRIVAL AT THE SITES AND SAMPLE COLLECTION}

\section{A. Arrival}

1. Check SWD1 program and ISCO sampler for what has taken place (hook laptop to CR10 via modem cable) then download records using telcom file (com, ind, or res) $1 \mathrm{tf}$ and note time when situation code 222 began which tells when an event began; then add 15 min. to tell when sample \#1 in bot\#2 was taken, etc. (to see when you need to manually sample)

Check total precip. that has fallen and stage

How many samples by ISCO have been taken? What is the time for the nonISCO sample?

If a storm event looks representative, ice down ISCO samples and then proceed with taking the grabs. Note that some of the grab sampling bottles have preservatives in them. Avoid losing preservative when filling these bottles.

B. Grab samples

1. Take the grab samples while wearing latex gloves within an hour after the runoff commenced as follows:

a. oil and grease - fill 32-oz Quanterra glass bottle at midstream; do not rinse bottle; leave small air space; cool to $4^{\circ} \mathrm{C}$ (preservative already in bottle).

b. total residual chlorine, field $\mathrm{pH}$, field specific conductance, and field temperature - fill 100 -mL poly bottle at midstream; use the $\mathrm{HACH}$ kit to test residual chlorine; determine temperature with the thermometer directly in the stream.

c. VOC's - fill three 40-mL septum-capped Quanterra vials at midstream and cap with no headspace; do not rinse bottle; protect sample from sunlight; if chlorine is present $\left(>0.1 \mathrm{mg} / \mathrm{L}\right.$ ), add 4 drops of $10 \%$ sodium thiosulfate to each vial; cool to $4^{\circ} \mathrm{C}$ (preservative already in bottle).

d. bacteria - fill three 500-mL glass bottles at midstream; hold bottles upside down below the water surface and fill by holding right side up angled slightly upstream (there should be no water from the surface in the sample); cover bottle opening with aluminum foil; if chlorine $\left(>0.1 \mathrm{mg} / \mathrm{L}\right.$ ) is present, add $25 \mathrm{mg}$ of ascorbic acid; cool to $4^{\circ} \mathrm{C}$.

e. cyanide - fill 8-oz Quanterra poly bottle at midstream; do not rinse bottle; if total residual chlorine $\left(>0.1 \mathrm{mg} / \mathrm{L}\right.$ ) is present, add $0.6 \mathrm{~g}$ of ascorbic acid; cool to $4^{\circ} \mathrm{C}$ (preservative already in bottle). 
f. total phenols - fill 16-oz Quanterra glass bottle at midstream; do not rinse bottle; leave a small air space; cool to $4^{\circ} \mathrm{C}$ (preservative already in bottle).

g. record collection times and gage heights for grab samples on a field log.

h. put date and time of collection of sample on the grab collection bottle labels.

C. Stream gaging

1. Make discharge measurement to verify rating, if available. If no rating for site, make adequate measurements to define a rating curve (can also use falling stage to define curve).

2. The SWD1 program will be set to collect stage height and precipitation at 1-minute intervals during an event and 5-minute intervals after an event.

D. Discrete samples for compositing

1. The ISCO sampler will be programmed to collect $3,750 \mathrm{~mL}$ every 15 minutes once the sampler is triggered by a specific gage height. Three $3,750 \mathrm{~mL}$ samples will be collected by this sampler. The rest of the samples for the composite will be collected manually by wading in the stream and filling the 1-gallon glass bottles.

2. Every 15 minutes during the storm event (beginning 15 minutes after the ISCO sampler has collected its last sample), collect a discrete sample in the 1-gallon glass sample collection bottles and chill immediately. Sampling continues for a maximum of 3 hours, or until the gage height returns to its pre-storm level after the storm has ended. A maximum of 13 discrete samples for later flow-weighted compositing are collected (15-minute intervals for 3 hours). No preservatives are added to these discrete samples.

3. If bottles are available, collect additional samples during the runoff peak. For example, collect two 1-gallon bottles near and at the peak. The final volume needed for compositing is about 12 liters.

4. Put date and time of collection of sample on the discrete collection bottles.

E. Post sampling at site

1. After the sampling event is completed, copy gage heights and associated times that correspond to sample collection to the field forms. Download data collected during storm event from SWD1 system. Write down time ISCO sampler took sample, what bottles, and sample volume taken. Use ISCO program to verify.

2. Shut off ISCO sampler (will return later to clean equipment and turn ISCO back on).

3. Check desipak indicators for the ISCO sampler and SWD1 system. Replace if needed.

4. Take samples collected to Sioux Falls water treatment plant. Three people will remain at the water treatment plant to do sample preparation and shipping. Rest of people will go to motel, return to Huron, or resume field trips.

\section{POST SAMPLING (PREPARATION AND SHIPMENT OF SAMPLES)}

A. General

1. Compositing will be done immediately after the storm event.

2. Bacteria samples will be done at the Sioux Falls water treatment plant as follows:

a. auger will be prepared at the water treatment plant

b. fecal coliform (range needed for count: 20 - 60)

c. fecal streptococcus (range needed for count: 20 - 100)

d. total coliform (range needed for count: 20-80)

e. reference "Guidelines for the Collection of Water-quality Samples in the S.D. District" for how to do bacteria analyses. Also, prepare media as shown in bacteria-T kit.

f. take 500-mL glass bacteria bottles back to Huron for sterilizing

3. If composite equipment is not already clean, clean with same procedure as sample bottles.

B. Composite samples: (see samples table for bottle numbers corresponding to constituents):

1. Determine appropriate volume required from each discrete sample. Note that about 12 liters of composite sample is needed to fill all bottles with some allowance for rinsing. Record discharge value corresponding to each discrete sample using rating with time and stăge 
information or actual stream gaging data done when storm occurred. Add up the discharges for each discrete sample (QTOTAL). Calculate the volume required from each sample (VSAMPLE) to be composited using the cone splitter. Check to make sure you have adequate discrete sample volume, especially when the peak occurred. Use a graduated cylinder to measure volumes.

where

$$
\text { VSAMPLE }=(\text { QSAMPLE } / \text { QTOTAL }) * \text { VTOTAL }
$$

VSAMPLE = required volume of discrete sample, in liters;

QSAMPLE = discharge associated with discrete sample, in cubic feet per second;

VTOTAL = total volume for composite sample (about 12 liters is needed); and

QTOTAL = sum of discharges associated with discrete samples, in cubic feet per second.

Example: QTOTAL $=2,000 \mathrm{ft}^{3} / \mathrm{s}$ and QSAMPLE taken at the peak $=400 \mathrm{ft}^{3} / \mathrm{s}$.

VSAMPLE $=(400 / 2000) * 12=2.4$ liters

If there is less than 2.4 liters available from the peak sample, you may be able to still send in samples. Actually, only 9 liters is needed (not 12 liters) if you don't send optional bottles to the lab.

2. Use a magnetic stirring unit with teflon bar or a teflon stirrer to stir a discrete bottle. Use a peristaltic pump to pump out required volume (VSAMPLE). Use a graduated glass cylinder to do measuring.

3. Set up teflon-lined cone splitter with ten 1-gallon bottles. Flush splitter with sample water. Pour required volume from each discrete sample into splitter. Repeat until you have done all the discrete samples. This will distribute about 1 liter of sample to each of these ten bottles with extra volume for rinsing and waste (this assumes you have about 12 liters of volume from discrete samples).

4. Using a glass funnel, fill up the 32-oz Quanterra sampling bottles, except for the samples to be filtered, using one of the ten cone-splitter samples.
a. fill one 32-oz poly bottle for $\mathrm{BOD}, \mathrm{TSS}$, diss. $\mathrm{Cl} \& \mathrm{SO}_{4}, \mathrm{TDS}, \mathrm{pH}$, sp. cond., \& alkal.
b. fill two 32-oz glass bottles for acid base/neutral organics
c. fill two 32-oz glass bottles for pesticides
d. fill one 32-oz glass bottle for total petroleum hydrocarbons

5. Use the cone splitter to split a 1-liter sample into two 0.5 liters (set up cone splitter to go 10 sample bottles and then pour contents of five of bottles into one sample container).
a. fill one 16-oz glass bottle for COD, TOC, and total nutrients
b. fill one 16-oz poly bottle for toxic metals

6. Take a 1-liter sample and do the following:
a. use a peristaltic pump with attached filter unit to fill up 16-oz phosphorous glass bottle
b. repeat for $16-\mathrm{oz}$ diss. $\mathrm{Ca}, \mathrm{Mg}, \mathrm{K}, \& \mathrm{Na}$ poly bottle

7. If enough sample volume remains from original 10 cone samples, fill up two 32-oz glass bottles for optional organics and use cone splitter to split a 1-liter sample into two 0.5 liters and fill 16oz optional mercury glass bottle.

C. Shipment of samples

1. make sure all Quanterra bottles are labeled with date and time of collection (lab analysis required should already be on the bottle)

2. pack Quanterra bottles in coolers with ice

3. complete chain-of-custody forms and place in coolers with Quanterra samples

4. ship BOD sample using Federal Express (Note: Federal Express isn't open on Sundays; Quanterra is open on Saturdays). Ship rest of samples by regular mail. 


\section{REPEAT FOR ADDITIONAL TWO SITES IF APPLICABLE}

1. Clean cone splitter, funnels, cone-splitter bottles, peristaltic pumps and filter units, etc., with same procedure as bottles with the exception of air drying.

2. Proceed to IV.

VI. CLEAN ALL EQUIPMENT AND BOTTLES AS FOLLOWS:

A. Decontamination of sampling bottles and equipment

1. wash with non-phosphate detergent and water

2. rinse several times with tap water

3. rinse with deionized water

4. rinse with methanol

5. rinse with deionized water

6. cap bottles and lids with aluminum foil

7. air dry

8. document cleaning

B. Bottles and equipment storage

1. put away all equipment and bottles with the exception of the 151 -gallon bottles

2. return the 151 -gallon bottles to the sites

3. clean ISCO pump and tubing if possible (if not, will have to return later on to decontaminate equipment)

C. Return to Huron

1. Don't forget to bring bacteria samples (petri dishes in incubators) back

2. Will need to resterilize bacteria bottles before next sampling event

\section{GENERAL QUALITY ASSURANCE /QUALITY CONTROL}

A. Samples to be taken

1. 3 sampling events for each site for a total of 9 sampling events

2. 2 equipment blanks at one of sites (one before sampling commences and one at the end when all sampling is finished) (pump deionized water through unit after it is cleaned and fill up sample bottles)

3. 1 replicate done on one of the 9 sampling events

4. 1 extra set for (lab) matrix spikes and duplicate matrix spikes done on one of the 9 sampling events

B. Chain-of-custody procedures

1. A sample is considered to be under a person's custody if it is in the individual's physical possession, secured in a tamper-proof way by the individual, in the individual's sight, or is secured in an area restricted to authorized personnel.

2. Label sample with sample number, name of collector, date and time of collection, and site number. Sample bottle labels will be marked at the site.

3. A field log book or field form will be used and contain the following information:
a. purpose of sampling
b. location of sampling point
c. name and address of field contact
d. type of sample
e. number and volume of sample taken
f. description of sampling point and sampling method
g. date and time of collection
h. collector's name
i. sample distribution and how transported
j. references such as maps and photographs of the sampling site 
k. field observations and measurements

1. signature of personnel responsible for observations

4. A chain-of-custody record will accompany each sample or group of samples and include the following information:

a. sample number

b. signature of collector

c. date, time, and address of collection

d. sample type

e. signatures of persons involved in the chain of possession

f. inclusive dates of possession

g. analyses to be done in the lab including methods and parameters

5. The chain-of-custody record will be put in a plastic bag and included with the sample. A copy of this record will be saved. This record is to be returned with the cooler to Huron.

6. The sample custodian at the laboratory receives the sample, inspects its condition, reconciles label information against the chain-of-custody record, assigns a laboratory number, logs in the sample, and stores it in a secured storage room until it is assigned to an analyst.

7. The laboratory supervisor assigns the sample for analysis and is responsible for its custody.

\section{SAFETY PLAN}

A. National Pollutant Discharge Elimination Safety Policy and Guidance document

1. This document will be available at each site and at the Sioux Falls water treatment plant.

B. A medical surveillance program is required for this work. It will consist of the following:

1. Initial screening test

a. will be filled out by all personnel working at the sites

b. will be forwarded to WRD Safety Officer who will forward it through Office of Personnel to the DOI Medical Director for evaluation and recommendations by the consulting psychologist

2. Initial baseline medical examination will be done by a licensed physician before sampling commences

a. The examination will include the following:

(1) resting electrocardiogram

(2) blood scan (count \& plasma and red cell cholinesterase)

(3) liver and kidney function profiles

(4) urine scan

(5) vision and audiometric tests

(6) general physical

b. This examination will be completed for the six people.

c. A followup examination will be completed 12 months later.

d. Results will be forwarded to WRD Safety Officer who will forward it through Office of Personnel to the DOI Medical Director for evaluation and recommendations.

3. Immunization requirements

a. Six persons working at the sites will have an update of their tetanus immunizations and hepatitis B shots including administration of gamma globulin and update of their typhoid immunization.

4. First-Aid provisions

a. All personnel working at the sites shall be currently trained and certified in CPR and basic first-aid procedures.

b. Personnel shall have access to first-aid equipment.

c. All teams will have access to a cellular phone (call 911 for emergencies).

5. Records

a. All medical records and data pertaining to this project will be kept on file. 
C. Written project site inventory

1. All personnel will be briefed on the potential hazards of each site prior to actual sampling.

2. All sites are classified as Class D nonconfined sites.

3. Laboratory safety procedures already in force will be observed for any lab work done.

4. The applicable supervisors will be responsible for completing job hazard analysis forms (JHA) for each sampling site and the Sioux Falls water treatment lab prior to sampling.

5. Life preservers will be worn at all times when sampling.

6. Location of hospitals will be noted.

D. Written project site entry procedure (not applicable since all sites are nonconfined)

E. Training program and documentation

1. Two people from the teams will complete a NPDES 24-hour training course.

2. All personnel will complete 8-hour basic first-aid and a CPR training course.

3. In-force laboratory safety procedures will be used.

4. All training will be documented.

F. Written sample shipping and storage procedures

1. Chain-of-custody procedures will be used for all samples.

2. Disposal gloves will be used at all times when there is potential for contact with sample water.

3. Appropriate protective clothing will be worn.

4. All samples will be carefully packaged and labeled for NPDES sites.

5. All samples will be treated as hazardous and potentially biohazardous.

6. Double bagging of samples will be done.

G. Written guide for laboratory safety

1. Existing laboratory safety guide will be used.

H. Written spill cleanup plan

1. Existing spill cleanup plan will be used.

I. Written material and waste-disposal procedures

1. Existing material and waste-disposal procedures will be used. 